\title{
Moisture and Textural Variations in Unsaturated Soils/Sediments Near the Hanford Wye Barricade
}
P. R. Heller
G. W. Gee
D. A. Myers

March 1985

Prepared for the U.S. Department of Energy under Contract DE-AC06-76RLO 1830

Pacific Northwest Laboratory Operated for the U.S. Department of Energy by Battelle Memorial Institute 


\title{
DISCLAIMER
}

This report was prepared as an account of work sponsored by an agency of the United States Government. Neither the United States Government nor any agency thereof, nor any of their employees, makes any warranty, express or implied, or assumes any legal liability or responsibility for the accuracy, completeness, or usefulness of any information, apparatus, product, or process disclosed, or represents that its use would not infringe privately owned rights. Reference herein to any specific commercial product, process, or service by trade name, trademark, manufacturer, or otherwise, does not necessarily constitute or imply its endorsement, recommendation, or favoring by the United States Government or any agency thereof. The views and opinions of authors expressed herein do not necessarily state or reflect those of the United States Government or any agency thereof.

\author{
PACIFIC NORTHWEST LABORATORY \\ operated by \\ BATTELLE \\ for the \\ UNITED STATES DEPARTMENT OF ENERGY \\ under Contract DE-AC06-76RLO 1830
}

\begin{tabular}{|c|c|}
\hline \multicolumn{2}{|c|}{ Printed in the United States of America } \\
\hline \multicolumn{2}{|c|}{ Available from } \\
\hline \multicolumn{2}{|c|}{ National Technical Information Service } \\
\hline \multirow{2}{*}{\multicolumn{2}{|c|}{$\begin{array}{l}\text { United States Department of Commerce } \\
5285 \text { Port Royal Road }\end{array}$}} \\
\hline & \\
\hline \multirow{2}{*}{\multicolumn{2}{|c|}{$\begin{array}{l}\text { NIIS Price Codes } \\
\text { Microfiche A01 }\end{array}$}} \\
\hline & \\
\hline \multicolumn{2}{|c|}{ Printed Copy } \\
\hline & Price \\
\hline Pages & Codes \\
\hline 001-025 & A02 \\
\hline 026-050 & $A 03$ \\
\hline $051-075$ & A04 \\
\hline $076-100$ & A05 \\
\hline $101-125$ & A06 \\
\hline $126-150$ & A07 \\
\hline $151-175$ & $A 08$ \\
\hline $176-200$ & $\mathrm{~A} 09$ \\
\hline $201-225$ & A010 \\
\hline $226-250$ & A011 \\
\hline $251-275$ & A012 \\
\hline $276-300$ & A013 \\
\hline
\end{tabular}


MOISTURE AND TEXTURAL VARIATIONS IN UNSATURATED SOILS/SEDIMENTS NEAR

THE HANFORD WYE BARRICADE
P. R. Heller
G. W. Gee
D. A. Myers

March 1985

Prepared for

the U.S. Department of Energy

under Contract DE-AC06-76RLO 1830

Pacific Northwest Laboratory

Richland, Washington 99352 

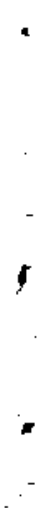

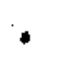




\section{ACKNOWLEDGMENTS}

The authors wish to acknowledge Dr. C. S. Simmons for providing the mathematical detail required for the travel time analyses presented in Appendix D; Kyle Ryan for his assistance with the laboratory work; Marvin Bultena, driller, $B$ \& $H$ No. 2 Drilling Company, Burbank, Washington; and Terry Liikala, field geologist. He also thank A. J. Currie and D. R. Simpson for their editorial support. 
During November and December 1983, soil samples were collected by Pacific Northwest Laboratory for hydrologic characterization of the partially saturated (vadose) zone sediments from five wells drilled near the Hanford Hye barricade, about $15 \mathrm{~km}$ northwest of Richland, washington.

The samples were taken from each of five boreholes in 1.5-m segments down to the water table or to a depth where further drilling became impossible, whichever was deeper. The samples were collected and handled in such a manner as to minimize water loss through evaporation. The field moisture content was determined for each sample, and for three of the five boreholes the water potential at the field moisture content was also measured. Other characterization included textural analysis, water retention characteristics, hydraulic conductivity, and soil chemistry.

From the laboratory data, trave1 time (i.e., the time necessary for water to move a distance of $43 \mathrm{~m}$, from the soil surface to the ground water) estimates were calculated: they range from $<100$ years to $>600$ years for annual water influx rates that ranged from 0.5 to $5.0 \mathrm{~cm} / \mathrm{yr}$.

The soil properties determined in this study will aid in modeling the transport of water and chemicals (e.g., radionuclides) to the ground water at the Hanford site. 


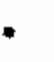

. 


\section{CONTENTS}

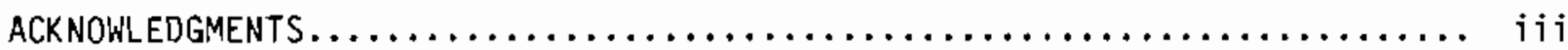

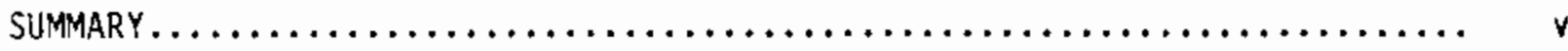

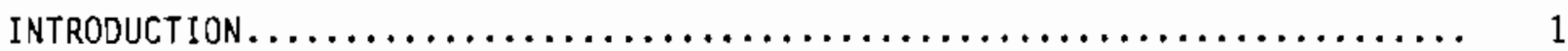

METHODS......................................... 4

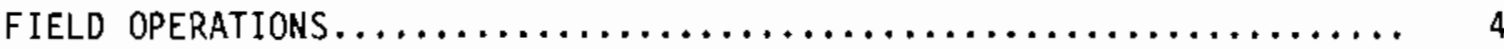

SAMPLING DETAILS............................. 5

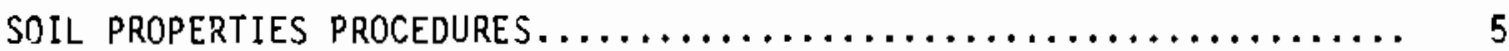

Field Moisture Content......................... 5

Water Potential............................... 6

Water Retention............................. 7

Hydraulic Conductivity........................ 7

Particle size................................ 8

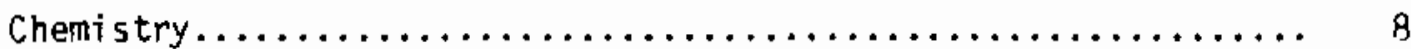

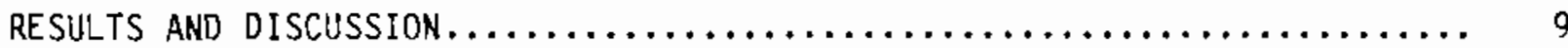

PHYSICAL CHARACTERIZATION............................ 9

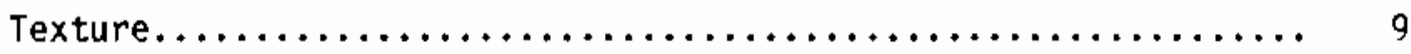

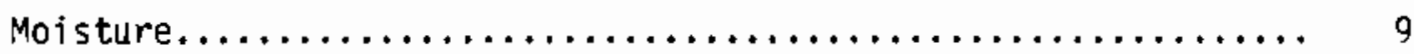

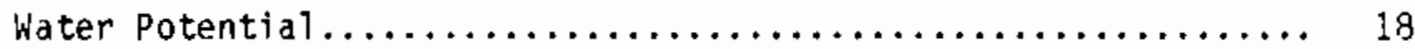

Hydraulic Conductivity........................... 19

Chemical Properties............................. 19

Travel Time Estimates........................... 19

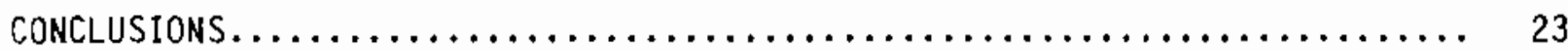

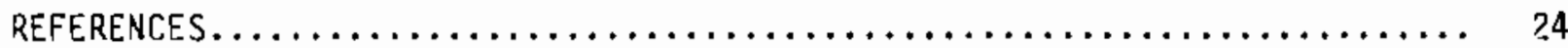




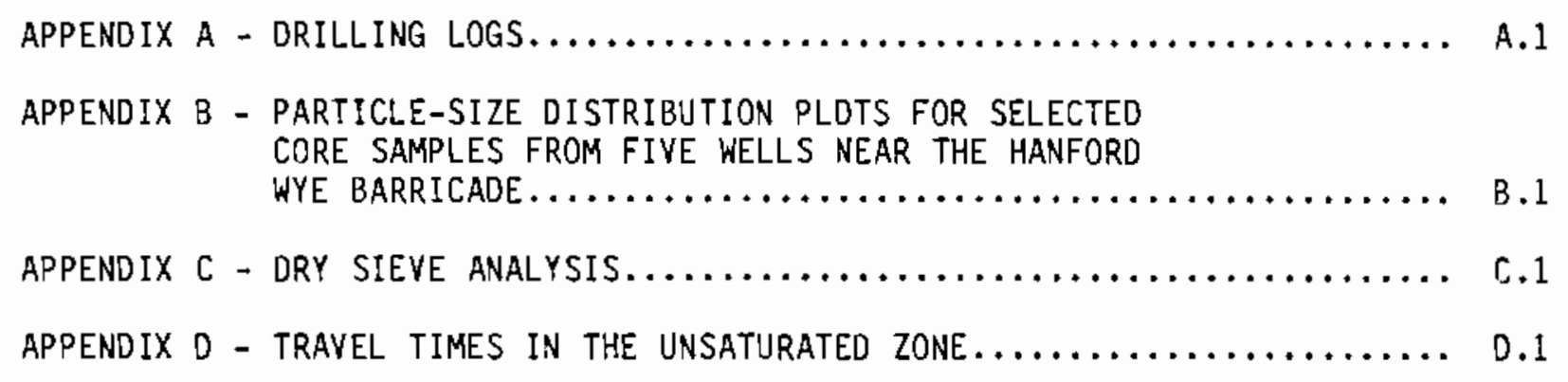




\section{FIGURES}

1. Location of Boreholes near the Hanford Wye Barricade............. 3

\section{TABLES}

1. Moisture Analysis for Core Samples from Five Wells near the Hanford Wye Barricade................................ 10

2. Mechanical Analysis for Core Samples from Five Wells near the Hanford Wye Barricade............................... 14

3 Hydraulic Conductivities of Eight Core Samples from Borehole \#3..... 20

4. Chemical Analysis for Core Samples from Five Boreholes near the Hanford Wye Barricade............................. 21

5. Estimated Travel Times for Water Movement from Soil Surface to a 43-m-Deep Water Table Using Borehole \#3 Soil Characteristics

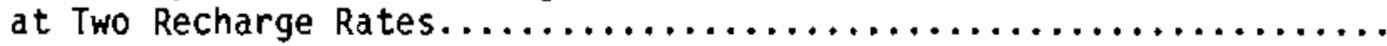




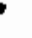

. 


\section{INTRODUCTION}

For the past 15 to 20 years, extensive hydrologic studies of the partially saturated (vadose) zone (a) at the U.S. Department of Energy's Hanford site have centered on using the zone as a long-term radioactive waste storage area (Browne11 et a1. 1975; Brown and Isaacson 1978; Jones 1978; Jones and Gee 1984; Reisenauer 1963). The vadose zone has also been considered as a buffer or delay zone that could extend the travel time of contaminants that might potentially seep to ground water from waste-processing operations or powerproduction facilities. The safety of buried radioactive wastes depends in part on the hydrologic isolation of the radionuclides from the fairly deep groundwater table at the Hanford site (Galley 1966; National Academy of Sciences $1957,1976,1978)$.

Past work at the Hanford site indicated that the vadose zone sediments remain fairly dry under the existing arid climate conditions (Enfield, Hsieh and Warrick 1973; Jones 1978; Jones and Gee 1984). However, the soils and sediments at the Hanford site, although highly variable, are generally coarse in texture and drain readily (Newcomb, Strand and Frank 1972; Routson and Fecht 1979). When excess water (from irrigation, liquid waste disposal, or increased precipitation) is applied at the surface, these soils and sediments can readily transmit water downward below the root zone such that further additions of water can be a source for deep drainage to the water table. Recent studies indicate that, when above-normal precipitation occurs, significant amounts of water can be transmitted below the root zone on coarse-textured soils at the Hanford site (Jones and Gee 1984; Kirkham and Gee 1984). Unfortunately, only limited hydrologic characterization has been completed on the Hanford site sediments; hence, the analysis of vadose zone water flow remains incomplete.

(a) The partially saturated (vadose) zone can be defined as the zone of geologic material (e.g., soils, sediments, and rocks) that lies between the land surface and the deepest water table. Generally, water in this zone is under pressure that is less than atmospheric (sometimes called negative pressure). At least some of the soil voids contain air or other gases at or near atmospheric pressure. At the Hanford site, this zone ranges in thickness from $15 \mathrm{~m}(45 \mathrm{ft})$ to over $100 \mathrm{~m}(300 \mathrm{ft})$. 
This report documents a recent effort to hydrologically characterize certain vadose zone sediments at the Hanford site. The report details measurements of field water contents for samples collected from five boreholes drilled a few kilometers northwest of the Hanford Wye barricade and about $15 \mathrm{~km}$ northiest of Richland, Washington (Figure 1). Capillary pressure (matric water potential) data were taken on samples from three of the five holes. Laboratory analyses were performed to determine water retention characteristics, hydraulic conductivity, particle size, calcium carbonate content, $\mathrm{pH}$, and electrical conductivity. Results are tabulated by hole and depth, and a discussion is provided concerning the use of this information to estimate rates of flow through the unsaturated zone. 


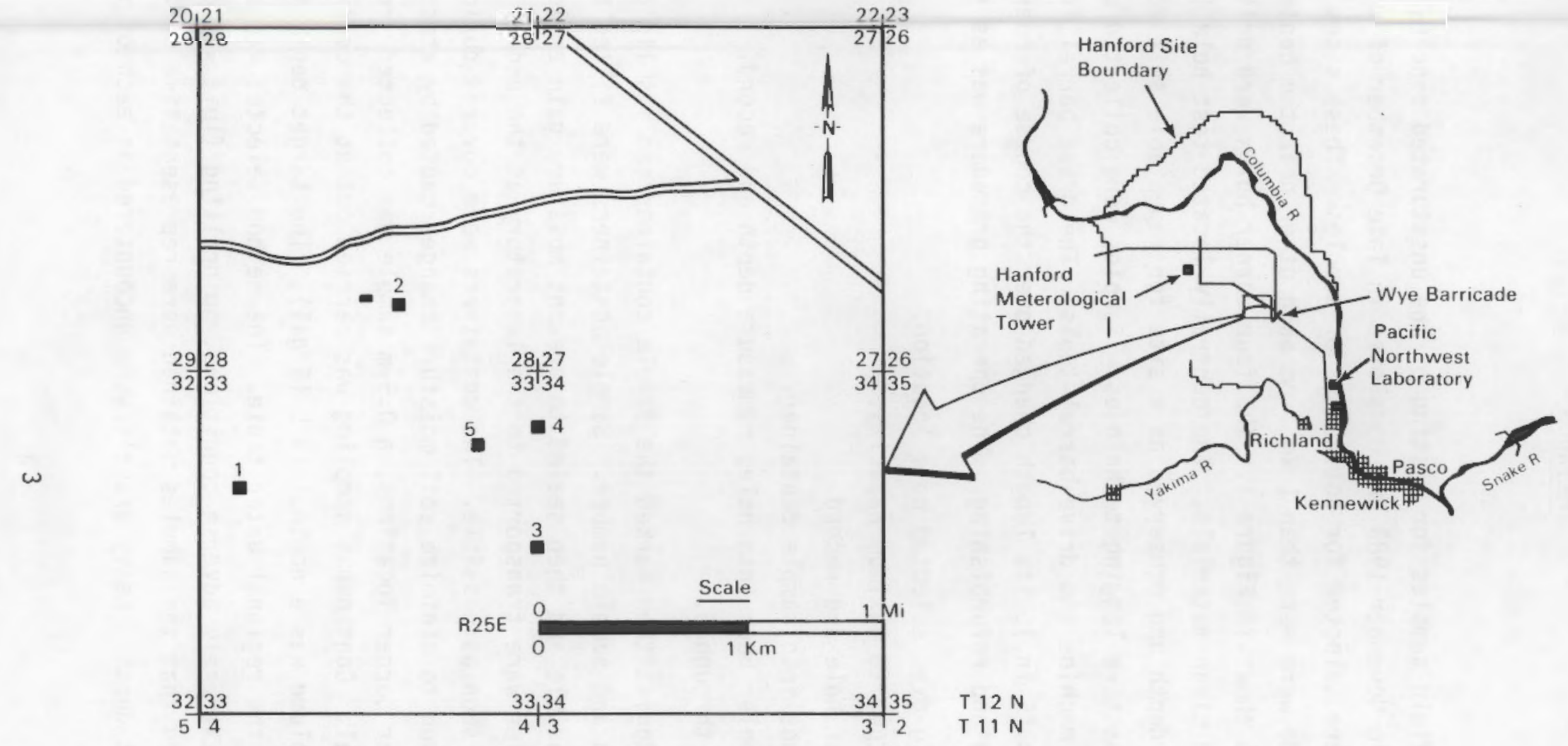

FIGURE 1. Location of Boreholes near the Hanford Wye Barricade 


\section{METHODS}

\section{FIELD OPERATIONS}

Collection of field samples for testing of the unsaturated zone in this area was initiated in November 1983 and completed in late December of the same year. Five sites were selected for collection of samples. These sites are spaced such that none were more than $1 \mathrm{~km}$ from each other near the center of the rectangular area shown in Figure 1. The four corner holes were drilled and then backfilled with clean materials. The centrally located test hole (\#5) was cased to its entire depth and preserved as a site for repeatable soil moisture analyses using radioactive logging techniques. Samples were collected using a percussion drilling machine and drive-barrel tools. The drive barrel inside diameter was $12.7 \mathrm{~cm}$ (5 in.); its length changed over the course of operations because of reforming and refurbishing. The operating procedure was as follows:

1. Set up drill rig over selected hole location.

2. Drive sampler tube to maximum capacity.

3. Measure depth of hole and record.

4. Empty sample tube into sample container.

5. Lower drive sampler back into hole; remeasure depth and record.

6. Repeat steps 2 through 5 .

The onsite geologist then marked the sample container and its lid according to well location and sample number. Sample containers were filled to as near capacity as feasible and then sealed to prevent moisture gain or loss during handling. Samples were transported to the laboratory at the end of each drilling day, or as soon as possible. The containers were covered during each intervening sample run to minimize soil moisture changes caused by atmospheric contact. At the four corner locations, a $0.5-\mathrm{m}$ sample was collected from each 1.5-m (5-ft) interval. Continuous sampling was carried out at the central location. Sample volume was a nominal $19 \mathrm{~L}(5 \mathrm{gal})$. The target depth for each of the holes was to the regional water table. The method selected was such that, except under extremely adverse conditions, no drilling fluid would be needed. This ensured that the samples obtained were representative of the actual conditions at depth. Heavy gravels were encountered in each of the 
holes near the water table. It became necessary to change over from drivebarrel methods to hard tools in four of the five holes. This changeover resulted in the lowermost samples being inappropriate for water-content analysis and biased the particle-size analysis toward the smaller size range. Brilling logs for all five boreholes are included in this report (see Appendix A).

SAMPLING DETAILS

From each core segment taken from a borehole, a $0.5-m$ section was saved for laboratory analysis in sealed airtight plastic buckets. Fron borehole \#5 (see figure 1 ), each core segment was saved in $0.75-m$ sections for a complete field water content analysis over the entire profile. All other analyses for borehole \#5 were performed on only the odd-numbered samples, to be consistent with the other boreholes; that is, a $0.5-\mathrm{m}$ section of every odd-numbered $1.5-\mathrm{m}$ segment was used for analysis.

Samples were collected to the depth of the water table or to the depth where further drilling became impossible, whichever was reached first. For boreholes \#2 through \#5, water was added as a drilling lubricant at about 25 to $28 \mathrm{~m}$; therefore, no water contents were obtained for the samples taken at and below this level.

Forty samples, eight from each borehole, were chosen for detailed analysis, based on visual texture changes down through the profile. One sample was selected to represent each of the visually distinct layers in the profile.

\section{SOIL PROPERTIES PROCEDURES}

\section{Field Moisture Content}

Field moisture content was determined on all samples. Samples were taken at the depths indicated in the previous section by core borehole techniques and placed imnediately in vapor-tight containers in the field. The samples were first logged into the laboratory using the field $\log$ information recorded on the buckets. Before the seal was broken on the lid, the samples were mixed by 
rolling the bucket to evenly distribute the water and to readsorb the condensation on the lid. Subsamples for moisture content were taken quickly to ensure minimum water loss caused by evaporation. These subsamples were weighed and oven-dried ( $16 \mathrm{~h}$ or more at $110^{\circ} \mathrm{C}$ ) to detemine moisture content according to ASTM procedure D 2216 (ASTM 1980).

Water Potential

When subsamples were taken from boreholes \#3 through \#5 for the field moisture content analysis, a second set of subsamples was collected to determine the water potential at the field moisture content. A comercial psychrometer sample changer (a) was used to determine the water potential. The samples were packed into small cups $1.4 \mathrm{~cm} \times 1.2 \mathrm{~cm}$ (diameter $\times$ height). The cups were put into vapor-tight chambers in the psychrometer sample changer. After approximately $1 \mathrm{~h}$, the relative humidity was measured with a miniature thermocouple psychrometer. The psychrometer measures the wet bulb depression (humidity) in a closed chamber directly above the sample using a miniature thermocouple connected to a microvolt sensing unit. The equilibrium vapor pressure, or relative humidity, can be related directly to the water potential of the water in the sample (Campoell 1977). The relationship between the water potential and the relative humidity can be written as follows:

$$
\Psi=-(R T / M) \ln (R H / 100)
$$

where

$$
\begin{aligned}
\psi & =\text { total water potential } \\
\mathrm{R} & =\text { universal gas constant } \\
\mathrm{T} & =\text { Kelvin } \\
\mathrm{M} & =\text { molecular weight of water } \\
\mathrm{RH} & =\text { relative humidity. }
\end{aligned}
$$

(a) Product of Decagon, Inc., Pullman, WA 99163. 
Water Retention

Water retention characteristics were measured at $0.1,1.0$, and 15.0 bars applied pressure for each sample using a pressure plate extractor(a). Equilibrium water contents were obtained by packing samples in containing rings on a porous ceramic plate where they were saturated and pressure-drained in the extractor.

Both the samples and porous plate were brought to saturation by allowing an excess of water to stand on the surface of the plate for $24 \mathrm{~h}$. On complete saturation, the plate was placed in the extractor vessel and the internal air pressure raised to the desired test level. Equilibrium was reached when the drainage ceased. At the end of the run, the samples were weighed and ovendried to deternine the moisture contents. Water-content data are tabulated in terms of the associated matric water potential expressed in -bars. At equilibrium, the applied pressure is equal to the matric water potential (Richards 1965).

\section{Hydraulic Conductivity}

Hydraulic conductivity on each of the 40 predetermined samples was determined using a constant head method (Klute 1965). In this method, the sample is placed in a container $(8.5 \mathrm{~cm}$ diameter, $9 \mathrm{~cm}$ high) and enclosed with lids having an inflow valve at one end and an outflow valve at the other end. The inflow valve is connected to a constant head device; the outflow valve is connected to a collection vessel. The sample is saturated before any test runs are done. An initial time is recorded and water is allowed to flow through the sample for a predesignated amount of time. The amount of discharge is recorded. The hydraulic conductivity is determined using the following equation:

$$
K=\frac{L}{\Delta H} \frac{Q}{A t}
$$

(a) Product of Soilmoisture Equipment Corporation, Santa Barbara, CA 93105. 
where

$L=$ length of the sample

$\Delta H=$ hydraulic head difference

$Q=$ volume of water that passes through the sample in known time ' $t$ '

$A=$ cross-sectional area of the sample.

\section{Particle Size}

Particle size was determined on two separate bases, depending on whether the particles were larger or smaller than $2 \mathrm{~mm}$. Particle sizes larger than 2 mm were determined by dry sieve analysis using sieve sizes of 3 in., 2 in., $1 \mathrm{in.,} 3 / 4 \mathrm{in.,} 1 / 2 \mathrm{in}$, and $4.75 \mathrm{~mm}$ and $2.0 \mathrm{~mm}$ (No. 4 and No. 10 mesh Tyler numbers, respectively). Size distribution was done in accordance with ASTM procedure D 422 (ASTM 1972). For all samples, sand, silt, and clay distributions were determined based on only the <2-mm-sized particles from each large sample. The 40 predetermined samples were analyzed for a complete distribution curve, except for dispersion of the sample, by ASTM procedure D 422 (ASTM 1972). Sample dispersion was done using an ultrasonic homogenizer for more complete dispersion of the particles.

Chemistry

The cation exchange capacity (CEC) for each of the 40 samples tested was done by sodium saturation and sodium determination by atomic adsorption (Chapman 1965). The $\mathrm{CaCO}_{3}$ content was determined using a volumetric calcimeter method (Allison and Moodie 1965). The pH and electrical conductivity were determined on a 1:1 soil extract (Bower and Wilcox 1965). 


\section{RESULTS AND DISCUSSION}

PHYSICAL CHARACTERIZATION

The following physical characteristics for the borehole samples were analyzed: texture, moisture, water potential, hydraulic conductivity, and chemical properties. Travel time estimates were made based on the collected data.

Texture

Tables 1 and 2 list the results of the physical characterization completed for all samples from the five boreholes. Sieve analysis results (see Appendix c) confirm that, at this site, the soils are typically coarse-textured, with clay contents of all samples generally $<5 \%$ and sand contents ranging from 60 to $90 \%$ or more. Silt contents varied considerably, ranging from $<10$ to $>60 \%$. The gravel and stone content of the material was also highiy variable, ranging from 0 to over $60 \%$ by weight. The particle-size distributions for these materials are presented graphically in Appendix $B$. The data reflect an extremely heterogeneous profile indicative of the glacial-fluvial processes that were responsible for the formation of the sediment layers (Routson and Fecht 1979).

\section{Moisture}

Previous reports (Benson, Nelson and Alkine 1963; McHenry 1957; Routson and Fecht 1979) have documented soil properties. However, none clearly documents the field moisture status of the sediment profiles sampled. The Routson and Fecht (1979) study of 12 wel1s located south of the 200 East Area reported moisture contents, but indicated that the values (ranging from 0.2 to 3.2 wt:o) represented a "minimum moisture;" the authors suggested that most samples had dried during storage, prior to analysis.

As indicated in the description of sampling and methods, we designed the study primarily to assess the moisture content of the sediment profile. The field moisture content values reported in Table 1 are generally higher than those reported by Routson and Fecht (1979). The values that we measured ranged from 2 to $15 \mathrm{wt} \%$. The higher field moisture contents (those above 10\%) are 
TABLE 1. Moisture Analysis for Core Samples from Five Wells near the Hanford Wye Barricade

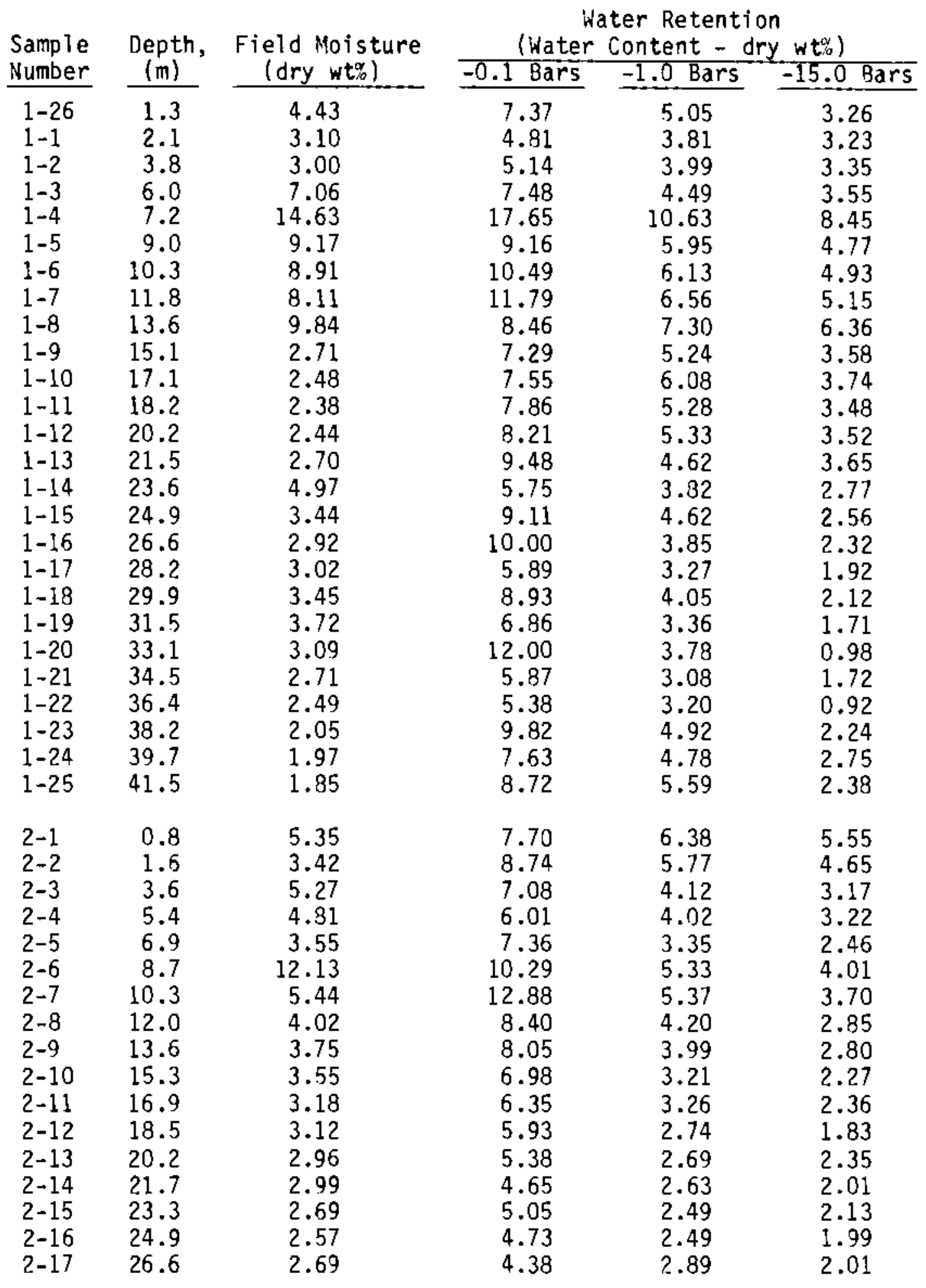


TABLE 1. (contd)

\begin{tabular}{|c|c|c|c|c|c|}
\hline \multirow{2}{*}{$\begin{array}{l}\text { Sample } \\
\text { Number }\end{array}$} & \multirow{2}{*}{$\begin{array}{l}\text { Depth, } \\
\text { (m) }\end{array}$} & \multirow{2}{*}{$\begin{array}{l}\text { Field Moisture } \\
\text { (dry wto) }\end{array}$} & \multicolumn{3}{|c|}{$\begin{array}{l}\text { Water Retention } \\
\text { (Water Content - dry wto) }\end{array}$} \\
\hline & & & -0.1 Bars & -1.0 Bars & -15.0 Bars \\
\hline $\begin{array}{l}2-18 \\
2-19 \\
2-20 \\
2-21 \\
2-22 \\
2-23 \\
2-24 \\
2-25 \\
2-26 \\
2-27\end{array}$ & $\begin{array}{l}28.2 \\
30.0 \\
31.3 \\
33.5 \\
34.8 \\
36.4 \\
38.2 \\
39.7 \\
41.3 \\
42.7\end{array}$ & $\begin{array}{c}3.09 \\
2.40 \\
2.67 \\
-- \\
-- \\
-- \\
-- \\
-- \\
-- \\
--\end{array}$ & $\begin{array}{r}5.22 \\
13.38 \\
16.48 \\
12.72 \\
14.17 \\
13.93 \\
12.97 \\
13.81 \\
15.64 \\
4.08\end{array}$ & $\begin{array}{l}2.66 \\
7.11 \\
7.69 \\
7.42 \\
8.66 \\
7.66 \\
7.49 \\
7.56 \\
8.78 \\
2.56\end{array}$ & $\begin{array}{l}2.14 \\
4.51 \\
5.36 \\
3.34 \\
4.13 \\
3.94 \\
3.70 \\
3.57 \\
5.24 \\
1.63\end{array}$ \\
\hline $\begin{array}{l}3-1 \\
3-2 \\
3-3 \\
3-4 \\
3-5 \\
3-6 \\
3-7 \\
3-8 \\
3-9 \\
3-10 \\
3-11 \\
3-12 \\
3-13 \\
3-14 \\
3-15 \\
3-16 \\
3-17 \\
3-18 \\
3-19 \\
3-20 \\
3-21 \\
3-22 \\
3-23 \\
3-24 \\
3-25 \\
3-26\end{array}$ & $\begin{array}{r}1.6 \\
3.6 \\
5.2 \\
6.9 \\
8.5 \\
10.2 \\
11.6 \\
13.5 \\
15.1 \\
16.6 \\
18.4 \\
20.0 \\
21.7 \\
23.3 \\
24.8 \\
26.7 \\
28.2 \\
30.2 \\
31.5 \\
33.1 \\
34.8 \\
36.4 \\
38.1 \\
39.7 \\
41.3 \\
43.0\end{array}$ & $\begin{array}{l}5.87 \\
6.67 \\
8.74 \\
4.80 \\
4.23 \\
4.55 \\
4.89 \\
5.53 \\
6.16 \\
5.32 \\
6.78 \\
5.50 \\
6.47 \\
5.02 \\
4.07 \\
4.00 \\
3.54 \\
-- \\
-- \\
-- \\
-- \\
-- \\
-- \\
-- \\
-- \\
--\end{array}$ & $\begin{array}{r}4.57 \\
7.72 \\
8.14 \\
5.59 \\
5.60 \\
5.78 \\
4.89 \\
5.77 \\
5.65 \\
5.92 \\
5.59 \\
5.67 \\
7.69 \\
5.05 \\
4.59 \\
2.52 \\
4.08 \\
13.83 \\
12.56 \\
14.18 \\
12.88 \\
14.30 \\
12.12 \\
12.77 \\
13.26 \\
11.84\end{array}$ & $\begin{array}{l}2.55 \\
3.74 \\
4.50 \\
3.53 \\
3.91 \\
4.62 \\
3.87 \\
4.07 \\
4.48 \\
3.91 \\
4.00 \\
3.92 \\
2.22 \\
2.62 \\
3.11 \\
2.30 \\
3.71 \\
7.00 \\
8.46 \\
8.64 \\
7.37 \\
7.79 \\
6.50 \\
7.47 \\
7.83 \\
6.86\end{array}$ & $\begin{array}{l}2.35 \\
3.38 \\
3.43 \\
2.77 \\
2.68 \\
3.35 \\
3.19 \\
3.21 \\
2.95 \\
2.68 \\
2.89 \\
2.90 \\
2.70 \\
1.64 \\
2.54 \\
2.12 \\
3.10 \\
3.51 \\
4.52 \\
4.14 \\
3.96 \\
3.79 \\
3.46 \\
3.81 \\
4.03 \\
3.41\end{array}$ \\
\hline $\begin{array}{l}4-1 \\
4-2 \\
4-3 \\
4-4 \\
4-5 \\
4-6\end{array}$ & $\begin{array}{r}1.6 \\
3.8 \\
5.1 \\
7.2 \\
8.9 \\
10.2\end{array}$ & $\begin{array}{r}5.63 \\
4.36 \\
4.68 \\
10.86 \\
3.68 \\
3.17\end{array}$ & $\begin{array}{l}3.09 \\
4.75 \\
5.03 \\
9.51 \\
4.60 \\
4.09\end{array}$ & $\begin{array}{l}2.93 \\
4.30 \\
5.82 \\
8.81 \\
4.43 \\
3.95\end{array}$ & $\begin{array}{l}2.79 \\
3.77 \\
5.32 \\
6.50 \\
3.70 \\
3.19\end{array}$ \\
\hline
\end{tabular}


TABLE 1. (contd)

Water Retention

Sample Depth, Field Moisture

Number $\frac{(m)}{4-7} \quad$ (dry wto)

4-7 12.3

3.52

$4-8 \quad 13.8$

3.82

$4-9 \quad 13.3$

3.97

$4-10 \quad 16.7$

4.14

4-11 18.4

2.79

4-12 $\quad 19.8$

2.27

4-13 21.7

2.35

$4-14 \quad 23.3$

2.46

4-15 25.1

2.49

4-16 26.6

2.25

4-17 2B.2

4-18 29.9

4-19 $\quad 31.5$

4-20 33.1

4-21 34.8

4-22 36.4

4-23 38.1

4-24 39.5

4-25 41.3

--

$-$

$--$

$--$

$-$

$-$

$\overline{--}$

$--$

$5-1 \quad 1.5$

5-2 2.0

5.41

5.47

3.24

3.98

4.01

4.51

4.93

4.51

4.68

4.53

4.82

4.24

4.42

5.48

5.59

4.79

7.00

8.02

9.64

5.57

4.41

3.66

4.08

3.86
(Water Content - dry wto)

\begin{tabular}{|c|c|c|}
\hline 0.1 Bars & -1.0 Bars & -15.0 Bars \\
\hline 4.78 & 3.70 & 3.62 \\
\hline 4.41 & 3.66 & 3.51 \\
\hline 4.28 & 3.78 & 3.69 \\
\hline 5.58 & 4.24 & 3.51 \\
\hline 6.31 & 3.79 & 3.19 \\
\hline 10.00 & 5.55 & 3.40 \\
\hline 8.43 & 4.62 & 3.11 \\
\hline 5.78 & 3.42 & 2.50 \\
\hline 7.41 & 4.17 & 2.38 \\
\hline 6.47 & 3.70 & 2.86 \\
\hline 15.71 & 8.82 & 4.42 \\
\hline 14.09 & 8.05 & 4.20 \\
\hline 12.00 & 8.54 & 3.56 \\
\hline 14.29 & 8.21 & 3.80 \\
\hline 16.28 & 7.88 & 3.60 \\
\hline 19.32 & 8.20 & 3.81 \\
\hline 18.49 & 9.68 & 3.99 \\
\hline 11.17 & 4.34 & 2.06 \\
\hline 17.67 & 8.85 & 3.31 \\
\hline
\end{tabular}

6.89

5.01

3.56

7.38

3.93

2.99

7.48

4.26

3.22

6.26

3.92

3.04

8.45

3.56

3.02

4.92

3.21

2.93

4.51

3.75

3.20

4.06

3.23

2.95

5.12

4.17

3.19

7.33

6.33

4.87

5.00

4.02

3.07

3.92

3.20

2.48 
TABLE 1. (contd)

\begin{tabular}{|c|c|c|c|c|c|}
\hline $\begin{array}{l}\text { Sample } \\
\text { Number } \\
\end{array}$ & $\begin{array}{c}\text { Depth, } \\
\text { (m) }\end{array}$ & $\begin{array}{l}\text { Field Moisture } \\
\text { (dry wto }\end{array}$ & \multicolumn{3}{|c|}{$\begin{array}{l}\text { Water Retention } \\
\text { (Water Content - dry wto) }\end{array}$} \\
\hline $5-25$ & 18.0 & 3.70 & 3.62 & 2.94 & 2.28 \\
\hline $5-26$ & 18.7 & 3.54 & & & \\
\hline $5-27$ & 19.2 & 3.29 & 3.08 & 2.56 & 2.04 \\
\hline $5-28$ & 20.0 & 3.37 & & & \\
\hline $5-29$ & 20.7 & 3.86 & 3.29 & 2.27 & 1.91 \\
\hline $5-30$ & 21.3 & 3.42 & & & \\
\hline $5-31$ & 21.8 & 3.96 & 3.00 & 2.26 & 2.23 \\
\hline $5-32$ & 22.5 & 3.86 & & & \\
\hline $\begin{array}{l}5-33 \\
5-34\end{array}$ & $\begin{array}{l}23.1 \\
24.0\end{array}$ & $\begin{array}{l}4.11 \\
3.76\end{array}$ & 3.26 & 2.12 & 1.91 \\
\hline & $\begin{array}{l}24.6 \\
25.3\end{array}$ & & 2.90 & 1.75 & 1.70 \\
\hline $\begin{array}{l}5-37 \\
5-38\end{array}$ & $\begin{array}{l}25.8 \\
26.2\end{array}$ & $\begin{array}{l}3.08 \\
3.15\end{array}$ & 3.42 & 2.28 & 1.85 \\
\hline $5-39$ & 26.9 & 2.87 & 3.40 & 2.12 & 1.48 \\
\hline $5-40$ & 27.4 & 2.97 & & & \\
\hline $\begin{array}{l}5-41 \\
5-42\end{array}$ & $\begin{array}{l}27.9 \\
28.5\end{array}$ & $\begin{array}{l}2.93 \\
2.59\end{array}$ & 3.37 & 1.98 & 1.49 \\
\hline $\begin{array}{l}5-43 \\
5-44\end{array}$ & $\begin{array}{l}29.2 \\
29.7\end{array}$ & $\begin{array}{l}2.71 \\
2.54\end{array}$ & 4.31 & 2.21 & 1.61 \\
\hline $5-45$ & 30.2 & 2.30 & 6.89 & 3.21 & 2.13 \\
\hline $5-46$ & 30.7 & 3.48 & & & \\
\hline $5-47$ & $\begin{array}{l}31.2 \\
32.5\end{array}$ & $\begin{array}{c}3.93 \\
-=\end{array}$ & 8.91 & 4.63 & 2.85 \\
\hline $\begin{array}{l}5-48 \\
5-49\end{array}$ & $\begin{array}{l}32.5 \\
33.5\end{array}$ & $\begin{array}{l}-- \\
--\end{array}$ & 12.46 & 7.08 & 4.17 \\
\hline $5-50$ & 34.3 & -- & & & \\
\hline $5-51$ & 35.4 & -- & 9.55 & 5.75 & 4.00 \\
\hline $5-52$ & 36.4 & -- & & & \\
\hline $5-53$ & 37.1 & - & 10.72 & 5.97 & 4.99 \\
\hline $5-54$ & 38.1 & - & & & \\
\hline 55 & 38.9 & -- & 9.62 & 4.95 & 3.34 \\
\hline & 39.7 & - & & & \\
\hline
\end{tabular}


TABLE 2. Mechanical Analysis for Core Samples from Five Wells near the Hanford Wye Barricade

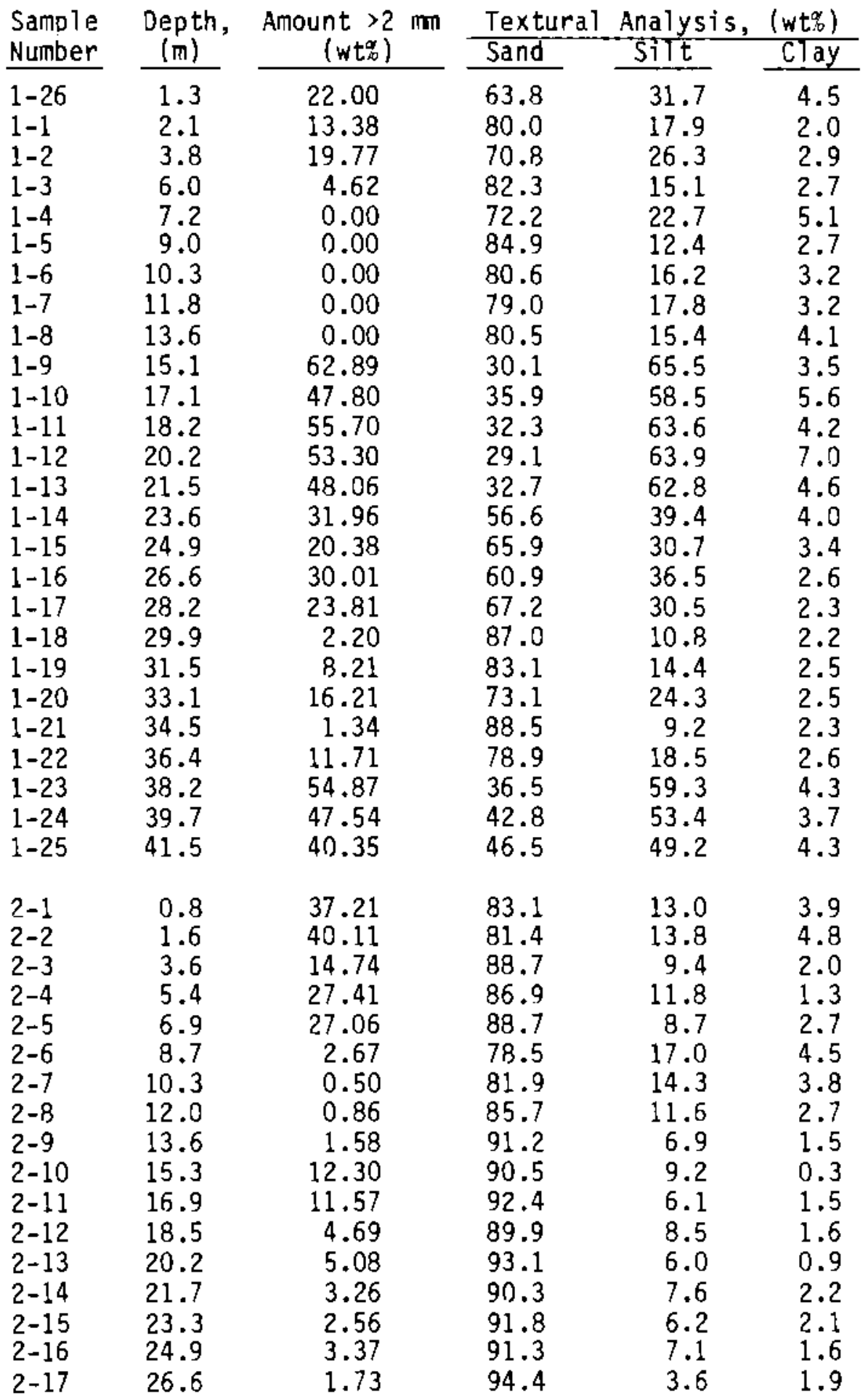


TABLE 2. (contd)

\begin{tabular}{|c|c|c|c|c|c|}
\hline $\begin{array}{l}\text { Sample } \\
\text { Number }\end{array}$ & $\begin{array}{c}\text { Depth, } \\
\text { (m) }\end{array}$ & $\begin{array}{c}\text { Anount }>2 \mathrm{~mm} \\
\left(\mathrm{wt}^{\alpha}\right)\end{array}$ & $\begin{array}{l}\text { Textural } \\
\text { Sand }\end{array}$ & $\frac{\text { Analysis, }}{\text { SiTt }}$ & $\begin{array}{r}\left(w t^{\alpha}\right) \\
\text { Clay } \\
\end{array}$ \\
\hline $\begin{array}{l}2-18 \\
2-19 \\
2-20 \\
2-21 \\
2-22 \\
2-23 \\
2-24 \\
2-25 \\
2-26 \\
2-27\end{array}$ & $\begin{array}{l}28.2 \\
30.0 \\
31.3 \\
33.5 \\
34.8 \\
36.4 \\
38.2 \\
39.7 \\
41.3 \\
42.7\end{array}$ & $\begin{array}{r}1.36 \\
55.81 \\
45.59 \\
36.68 \\
24.76 \\
15.19 \\
26.55 \\
13.53 \\
0.45 \\
14.45\end{array}$ & $\begin{array}{l}93.8 \\
68.0 \\
66.2 \\
69.7 \\
60.6 \\
69.8 \\
66.5 \\
66.8 \\
32.4 \\
90.7\end{array}$ & $\begin{array}{r}4.8 \\
28.0 \\
28.7 \\
23.0 \\
29.0 \\
22.3 \\
24.6 \\
24.7 \\
50.1 \\
5.5\end{array}$ & $\begin{array}{r}1.4 \\
4.0 \\
5.1 \\
7.3 \\
10.5 \\
8.0 \\
8.9 \\
8.5 \\
17.5 \\
3.8\end{array}$ \\
\hline $\begin{array}{l}3-1 \\
3-2 \\
3-3 \\
3-4 \\
3-5 \\
3-6 \\
3-7 \\
3-8 \\
3-9 \\
3-10 \\
3-11 \\
3-12 \\
3-13 \\
3-14 \\
3-15 \\
3-16 \\
3-17 \\
3-18 \\
3-19 \\
3-20 \\
3-21 \\
3-22 \\
3-23 \\
3-24 \\
3-25 \\
3-26\end{array}$ & $\begin{array}{l}1.6 \\
3.6 \\
5.2 \\
5.9 \\
8.5 \\
10.2 \\
11.6 \\
13.5 \\
15.1 \\
16.6 \\
18.4 \\
20.0 \\
21.7 \\
23.3 \\
24.8 \\
26.7 \\
28.2 \\
30.2 \\
31.5 \\
33.1 \\
34.8 \\
36.4 \\
38.1 \\
39.7 \\
41.3 \\
43.0\end{array}$ & $\begin{array}{r}0.10 \\
0.00 \\
0.00 \\
4.00 \\
9.11 \\
14.37 \\
8.36 \\
1.98 \\
6.96 \\
13.41 \\
4.09 \\
11.22 \\
0.07 \\
0.39 \\
4.89 \\
5.50 \\
39.53 \\
30.11 \\
21.59 \\
25.51 \\
30.11 \\
27.76 \\
40.14 \\
33.81 \\
37.25 \\
18.66\end{array}$ & $\begin{array}{l}88.6 \\
84.8 \\
87.0 \\
86.9 \\
88.4 \\
88.2 \\
89.0 \\
88.3 \\
90.6 \\
91.6 \\
89.8 \\
91.4 \\
86.7 \\
88.6 \\
90.6 \\
89.6 \\
88.2 \\
69.2 \\
69.6 \\
66.9 \\
88.4 \\
74.2 \\
52.4 \\
62.9 \\
67.7 \\
70.6\end{array}$ & $\begin{array}{r}9.5 \\
12.7 \\
10.4 \\
10.8 \\
8.5 \\
8.3 \\
7.9 \\
9.7 \\
7.1 \\
6.1 \\
7.7 \\
6.4 \\
10.5 \\
8.1 \\
6.6 \\
7.8 \\
8.7 \\
24.5 \\
22.5 \\
26.7 \\
6.3 \\
19.3 \\
41.2 \\
30.9 \\
24.9 \\
23.5\end{array}$ & $\begin{array}{l}1.9 \\
2.5 \\
2.6 \\
2.2 \\
3.1 \\
3.5 \\
3.1 \\
2.1 \\
2.3 \\
2.3 \\
2.5 \\
2.3 \\
2.9 \\
3.3 \\
2.8 \\
2.6 \\
3.1 \\
6.4 \\
7.9 \\
6.4 \\
5.3 \\
6.5 \\
6.4 \\
6.2 \\
7.4 \\
5.9\end{array}$ \\
\hline $\begin{array}{l}4-1 \\
4-2 \\
4-3 \\
4-4 \\
4-5 \\
4-6\end{array}$ & $\begin{array}{r}1.6 \\
3.8 \\
5.1 \\
7.2 \\
8.9 \\
10.2\end{array}$ & $\begin{array}{r}0.61 \\
9.73 \\
39.27 \\
0.00 \\
1.36 \\
5.90\end{array}$ & $\begin{array}{l}95.4 \\
90.0 \\
85.1 \\
81.0 \\
92.8 \\
89.1\end{array}$ & $\begin{array}{r}2.3 \\
7.3 \\
11.6 \\
14.2 \\
5.1 \\
10.1\end{array}$ & $\begin{array}{l}2.3 \\
2.7 \\
3.3 \\
4.8 \\
2.1 \\
0.7\end{array}$ \\
\hline
\end{tabular}


TABLE_2. (contd)

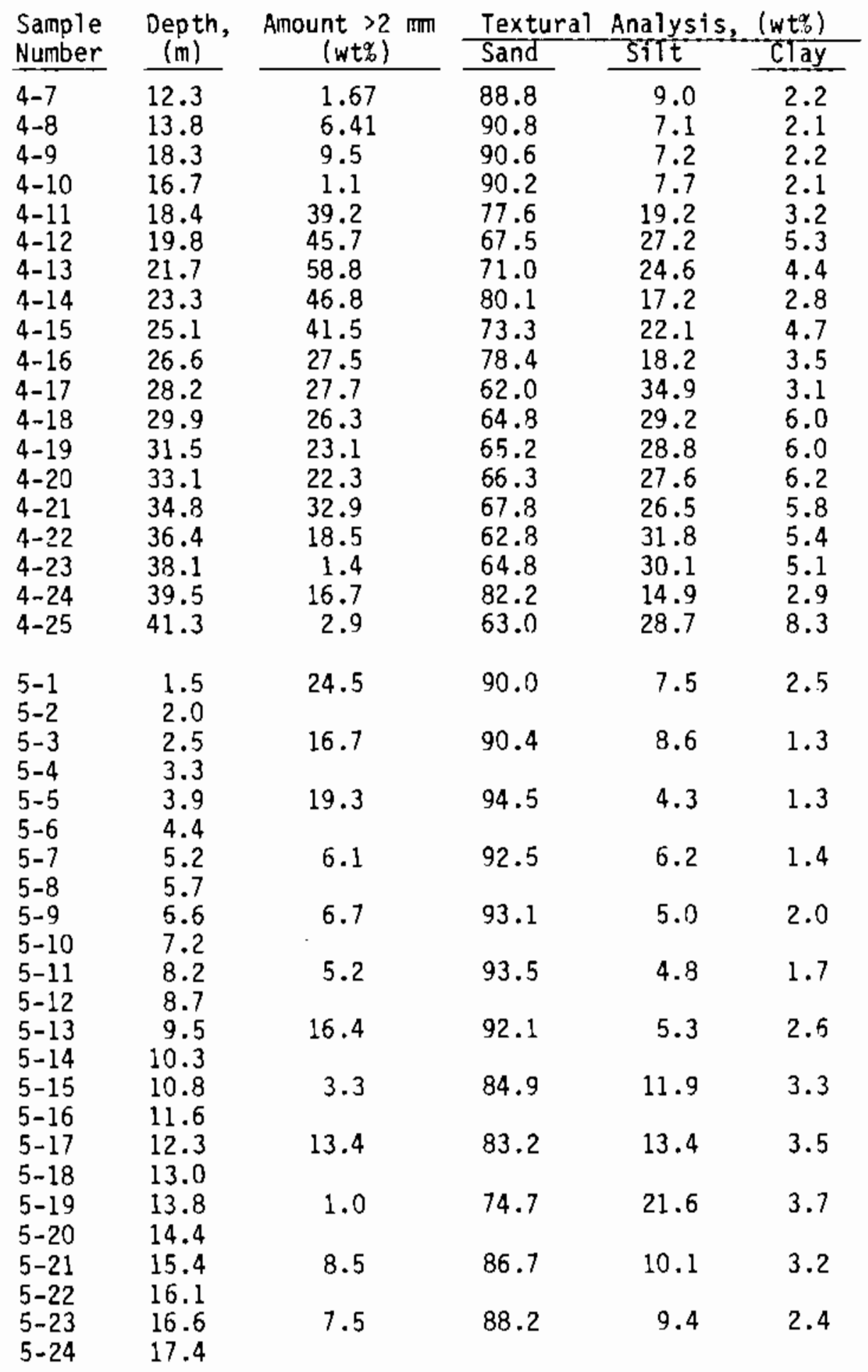


TABLE 2. (contd)

\begin{tabular}{|c|c|c|c|c|c|}
\hline $\begin{array}{l}\text { Sample } \\
\text { Number }\end{array}$ & $\begin{array}{l}\text { Depth, } \\
\text { (m) }\end{array}$ & $\begin{array}{c}\text { Amount }>2 \mathrm{~mm} \\
(\mathrm{wt} \%)\end{array}$ & $\begin{array}{l}\text { Textura1 } \\
\text { Sand }\end{array}$ & $\frac{\text { Analysis }}{\text { Siltt }}$ & $\frac{\left(w t_{0}^{\alpha}\right)}{\text { Clay }}$ \\
\hline $5-25$ & 18.0 & 8.2 & 86.6 & 10.2 & 3.2 \\
\hline $\begin{array}{l}5-26 \\
5-27\end{array}$ & $\begin{array}{l}18.7 \\
19.2\end{array}$ & 10.0 & 90.4 & 7.2 & 2.4 \\
\hline $5-28$ & 20.0 & & & & \\
\hline $\begin{array}{l}5-29 \\
5-30\end{array}$ & 20.7 & 11.1 & 92.1 & 5.8 & 2.1 \\
\hline $\begin{array}{l}5-31 \\
5-32\end{array}$ & $\begin{array}{l}21.8 \\
22.5\end{array}$ & 6.2 & 91.8 & 5.5 & 2.7 \\
\hline $\begin{array}{l}5-33 \\
5-34\end{array}$ & $\begin{array}{l}23.1 \\
24.0\end{array}$ & 0.6 & 89.9 & 6.9 & 3.2 \\
\hline $\begin{array}{l}5-35 \\
5-36\end{array}$ & $\begin{array}{l}24.6 \\
25.3\end{array}$ & 5.0 & 92.0 & 5.3 & 2.7 \\
\hline & & 18.0 & 90.6 & 6.4 & 3.0 \\
\hline $\begin{array}{l}5-39 \\
5-40\end{array}$ & $\begin{array}{l}26.9 \\
27.4\end{array}$ & 22.2 & 91.7 & 5.9 & 2.5 \\
\hline $\begin{array}{l}5-41 \\
5-42\end{array}$ & $\begin{array}{l}27.9 \\
28.5\end{array}$ & 5.0 & 91.0 & 6.6 & 2.4 \\
\hline $\begin{array}{l}5-43 \\
5-44\end{array}$ & $\begin{array}{l}29.2 \\
29.7\end{array}$ & 6.8 & 89.6 & 8.0 & 2.5 \\
\hline $\begin{array}{l}5-45 \\
5-46\end{array}$ & $\begin{array}{l}30.2 \\
30.7\end{array}$ & 32.7 & 83.2 & 13.8 & 3.0 \\
\hline $\begin{array}{l}5-47 \\
5-48\end{array}$ & $\begin{array}{l}31.2 \\
32.5\end{array}$ & 35.8 & 87.0 & 9.9 & 3.2 \\
\hline $\begin{array}{l}5-49 \\
5-50\end{array}$ & $\begin{array}{l}33.6 \\
34.3\end{array}$ & 23.5 & 65.1 & 27.8 & 7.1 \\
\hline $\begin{array}{l}5-51 \\
5-52\end{array}$ & $\begin{array}{l}35.4 \\
36.4\end{array}$ & 20.7 & 66.4 & 27.0 & 6.7 \\
\hline $\begin{array}{l}5-53 \\
5-54\end{array}$ & $\begin{array}{l}37.1 \\
38.1\end{array}$ & 19.4 & 64.3 & 27.9 & 7.9 \\
\hline $\begin{array}{l}5-55 \\
5-56\end{array}$ & $\begin{array}{l}38.9 \\
39.7\end{array}$ & 25.9 & 69.4 & 23.7 & 6.8 \\
\hline
\end{tabular}

consistently associated with fine-textured sediments (i.e., samples with higher silt and clay contents). Based on the measured water-retention values, the bulk of the data indicate water content values that are consistent with moisture contents associated with a draining profile $(0$ to -1.0 bar capiliary pressurel, particularly in the region from 5 to $20 \mathrm{~m}$ deep. Borehole $\# 3$, being the most uniform in texture, yielded the most uniformly wet profile, indicating that moisture redistribution and drainage had extended to at least a depth of $25 \mathrm{~m}$. (The moisture data at depths below 25 to $30 \mathrm{~m}$ are unavailable in all but 
borehole \#l because of difficulties in obtaining core material from the very coarse gravel/soil layers at this location.)

In cases where water contents appear drier than those measured at -1.0 bar on the pressure plate, the data are consistently associated with coarse samples that contain large portions of materials larger than $2 \mathrm{~mm}$ in size. Because the water retention values were run on materials $<2 \mathrm{~mm}$ in size, a correction of either the field water contents or the pressure plate water contents is necessary. The following relationship relates the field water content corrected for gravel (>2 mm-size material) to the laboratory water retention data (for material $<2$ man in size).

$$
W_{C}=\left(W_{U}-W_{G} f_{G}\right) /\left(1-f_{G}\right)
$$

where

$W_{c}=$ corrected field water content

$W_{U}=$ uncorrected field water content

$w_{G}=$ water content of gravel (>2 mm material)

$f_{G}=$ dry weight fraction of gravel in sample.

When this correction is applied to the field water contents (using Table 2 data and assuming $\left.f_{G} \sim 0.01\right)$ virtually all the data below a $5-m$ depth from all five boreholes can be shown to have water contents that fall within the range of those measured on the pressure $p l a t e$ between 0.1 and 1.0 bar. Field moistures consistently wetter than the measured -1.0 bar capillary pressure suggest that drainage is occurring and that evaporation is likely not occurring at great depths.

\section{Water Potential}

Samples were measured for water potential only in boreholes \#3, 4, and 5. In boreholes $\$ 3$ and \#5 the measured total water potential was found to be wetter than -1.0 bar for all samples. These data confirm that, in genera1, the soit remained wet at depth. For 5 samples in borehole \#4, the measured water potential was drier than -1.0 bars (ranging from -1.5 to -5.0 bars at depths from 17 to $24 \mathrm{~m}$ ). All other samples (11) were measured to be wetter than -1.0 bar. Sample desiccation or measurement error are possible explanations 
for the observed drier water potential at depth in test borehole \#4. Careful and detailed measurement of 17 samples from borehole $\# 3$ and 47 samples from borehole \#5 indicated that no samples to depths of $29 \mathrm{~m}$ had water potentials drier than -1.0 bars. The resolution of the water potential sensing unit is \pm 1.0 bar. However, we also detemined from pressure plate tests that, in general, samples with total water potentials wetter than -1.0 bar also had matric potentials wetter than -1.0 bar. These data support the concept of a draining profile at this site.

Hydraulic Conductivity

AT1 measurements were made on disturbed samples. The coarse sediments made it impossible to sample without noticeable segregation of material. Table 3 reports hydraulic conductivity values for the <2-mm-size fraction for eight samples from borehole \#3. Also included in Table 3 are measured hydraulic conductivity values on five bulk samples, which contained $>2-m m-s i z e$ materials. Note that for these samples, the $>2-m$ size ranged up to about $20 \mathrm{~mm}$. Coarser material was not sampled. The coarse fraction in each sample is documented in Table 2. The measured conductivities vary from $10^{-2}$ to $10^{-5} \mathrm{~cm} / \mathrm{s}$ and reflect moderate-to-high permeabilities indicative of coarse materials with a wide range of particle sizes. The reported values are considered representative of vertical permeabilities of the sediments. Because of the disturbed nature of the samples, no attempt was made to measure differences between vertical and horizontal permeabilities for these materials. Chemical Properties

Table 4 lists the chemical properties of selected samples from each borehole. No unusual chemical properties were noted in these sediments. They are alkaline with low cation exchange capacities and generally low carbonates. These findings are very similar to those reported by Routson and Fecht (1979) for 200 East Area sediments.

\section{Travel Time Estimates}

Travel time in the vadose zone can be defined as the time necessary for water to move from the soil surface to the water table. Travel time is a key 
TABLE 3. Hydraulic Conductivities of Eight Core Samples from Borehole \#3

\begin{tabular}{|c|c|c|c|}
\hline $\begin{array}{l}\text { Sample } \\
\text { Number }\end{array}$ & $\begin{array}{c}\text { Depth, } \\
\mathrm{m}\end{array}$ & Bulk Sample, $\mathrm{cm} / \mathrm{s}$ & $\measuredangle 2 \mathrm{~mm}, \mathrm{~cm} / \mathrm{s}$ \\
\hline $3-1$ & 1.6 & $1.2 \mathrm{E}-03$ & $1.2 \mathrm{E}-03$ \\
\hline $3-3$ & 5.2 & $1.0 \mathrm{E}-03$ & $1.0 \mathrm{E}-03$ \\
\hline $3-6$ & 10.2 & $1.1 \mathrm{E}-02$ & $2.5 \mathrm{E}-02$ \\
\hline $3-12$ & 20.0 & $6.8 \mathrm{E}-03$ & $1.4 \mathrm{E}-02$ \\
\hline $3-14$ & 23.3 & $3.7 \mathrm{E}-03$ & $3.7 \mathrm{E}-03$ \\
\hline $3-17$ & 28.2 & $4.0 \mathrm{E}-03$ & $6.0 \mathrm{E}-03$ \\
\hline $3-21$ & 34.8 & $1.2 \mathrm{E}-04$ & $1.6 \mathrm{E}-05$ \\
\hline $3-25$ & 41.3 & $3.4 E-04$ & $4.2 \mathrm{E}-05$ \\
\hline
\end{tabular}

parameter needed to estimate consequences for siting facilities where radioactive waste might be leached to ground water. For radioactive species (e.g., tritium, ruthenium, iodine, or organically complexed species that are sorbed little on soil or sediments), the major mode of concentration reduction is through decay; hence, long travel times are desirable. Travel times can be estimated using the hydrologic properties on the unsaturated sediments. Appendix 0 details the mathematical expressions needed to calculate the trave times. For unsaturated flow considerations, the major uncertainty is the annual seepage (recharge) rate that occurs at depth, below the zone of evaporation (top 2 to $3 \mathrm{~m}$ ). Much uncertainty still exists as to the actual recharge rate but, for our calculations, we made travel time estimates assuning 0.5 and $5.0 \mathrm{~cm} / \mathrm{yr}$ as steady-state recharge values. Table 0.2 (see Appendix D) shows that for borehole \#3, the measured water contents agree reasonably well with those predicted using exponential relationships of unsaturated conductivity and water retention, and assuming the recharge rates 1 ie between 0.5 and $5.0 \mathrm{~cm} / \mathrm{yr}$.

Travel times were analyzed in two ways. The first method assumed that the soil properties could be averaged over the entire depth $(43 \mathrm{~m})$. The second method separated the sediments into three zones, based on textural differences, and computed the travel times by summing the travel time in the individual zones. Table 5 tabulates the estimated travel times based on the properties reported for borehole \#3, using annual recharge rates of 0.5 and $5.0 \mathrm{~cm} / \mathrm{yr}$. 
TABLE 4. Chemical Analysis for Core Samples from Five Boreholes near the Hanford Wye Barricade

\begin{tabular}{|c|c|c|c|c|c|}
\hline $\begin{array}{l}\text { Sample } \\
\text { Number }\end{array}$ & $\underset{\mathrm{m}}{\text { Oepth, }}$ & $\begin{array}{l}C E C, \\
m e q / L\end{array}$ & $\underset{\mathrm{wtO}_{3}}{\mathrm{CaCO}_{3}}$, & $\begin{array}{c}\mathrm{pH}, \\
\text { units }\end{array}$ & $\begin{array}{c}\text { EC, } \\
\text { mmhos/cm }\end{array}$ \\
\hline $\begin{array}{l}1-26 \\
1-2 \\
1-8 \\
1-12 \\
1-16 \\
1-19 \\
1-22 \\
1-24\end{array}$ & $\begin{array}{r}1.3 \\
3.8 \\
13.6 \\
20.2 \\
26.6 \\
31.5 \\
36.4 \\
39.7\end{array}$ & $\begin{array}{r}8.0 \\
9.7 \\
13.9 \\
8.0 \\
6.0 \\
4.1 \\
4.2 \\
5.3\end{array}$ & $\begin{array}{l}0.20 \\
1.37 \\
1.04 \\
1.30 \\
0.86 \\
0.91 \\
0.96 \\
0.98\end{array}$ & $\begin{array}{l}8.2 \\
8.2 \\
8.2 \\
8.2 \\
8.3 \\
8.2 \\
8.3 \\
8.2\end{array}$ & $\begin{array}{l}0.10 \\
0.19 \\
0.16 \\
0.18 \\
0.16 \\
0.15 \\
0.15 \\
0.17\end{array}$ \\
\hline $\begin{array}{l}2-1 \\
2-4 \\
2-6 \\
2-10 \\
2-16 \\
2-19 \\
2-22 \\
2-25\end{array}$ & $\begin{array}{r}0.8 \\
5.4 \\
8.7 \\
15.3 \\
24.9 \\
30.0 \\
34.8 \\
39.7\end{array}$ & $\begin{array}{r}11.7 \\
9.5 \\
12.0 \\
6.2 \\
3.4 \\
6.4 \\
5.0 \\
3.1\end{array}$ & $\begin{array}{l}0.84 \\
1.09 \\
1.26 \\
1.27 \\
1.17 \\
0.67 \\
0.29 \\
1.38\end{array}$ & $\begin{array}{l}8.3 \\
8.4 \\
8.2 \\
8.3 \\
8.3 \\
8.3 \\
8.2 \\
8.2\end{array}$ & $\begin{array}{l}0.17 \\
0.14 \\
0.16 \\
0.13 \\
0.15 \\
0.19 \\
0.22 \\
0.22\end{array}$ \\
\hline $\begin{array}{l}3-1 \\
3-3 \\
3-6 \\
3-12 \\
3-14 \\
3-17 \\
3-21 \\
3-25\end{array}$ & $\begin{array}{r}1.6 \\
5.2 \\
10.2 \\
20.0 \\
23.3 \\
28.2 \\
34.8 \\
41.3\end{array}$ & $\begin{array}{l}4.4 \\
8.7 \\
8.2 \\
7.1 \\
3.7 \\
4.9 \\
4.8 \\
4.6\end{array}$ & $\begin{array}{l}0.38 \\
1.54 \\
0.76 \\
0.71 \\
1.15 \\
1.21 \\
0.46 \\
0.58\end{array}$ & $\begin{array}{l}8.0 \\
8.3 \\
8.2 \\
8.2 \\
8.3 \\
8.2 \\
8.1 \\
8.3\end{array}$ & $\begin{array}{l}0.16 \\
0.15 \\
0.15 \\
0.14 \\
0.15 \\
0.14 \\
0.23 \\
0.22\end{array}$ \\
\hline $\begin{array}{l}4-1 \\
4-3 \\
4-4 \\
4-8 \\
4-13 \\
4-19 \\
4-23 \\
4-25\end{array}$ & $\begin{array}{r}1.6 \\
5.1 \\
7.2 \\
13.8 \\
21.7 \\
31.5 \\
38.1 \\
41.3\end{array}$ & $\begin{array}{r}4.1 \\
21.0 \\
15.0 \\
7.2 \\
7.1 \\
5.4 \\
4.1 \\
10.0\end{array}$ & $\begin{array}{l}1.30 \\
1.35 \\
1.54 \\
0.69 \\
0.60 \\
0.45 \\
0.57 \\
0.26\end{array}$ & $\begin{array}{l}8.4 \\
8.2 \\
8.3 \\
8.2 \\
8.2 \\
8.4 \\
8.3 \\
8.1\end{array}$ & $\begin{array}{l}0.14 \\
0.15 \\
0.17 \\
0.17 \\
0.15 \\
0.15 \\
0.22 \\
0.21\end{array}$ \\
\hline $\begin{array}{l}5-1 \\
5-15 \\
5-17 \\
5-23 \\
5-33 \\
5-45 \\
5-51 \\
5-55\end{array}$ & $\begin{array}{r}1.5 \\
10.8 \\
12.3 \\
16.6 \\
23.1 \\
30.2 \\
35.4 \\
38.9\end{array}$ & $\begin{array}{l}7.2 \\
7.5 \\
7.9 \\
7.0 \\
3.5 \\
3.4 \\
4.1 \\
3.1\end{array}$ & $\begin{array}{l}1.28 \\
0.54 \\
0.68 \\
1.38 \\
1.29 \\
1.07 \\
0.29 \\
0.41\end{array}$ & $\begin{array}{l}8.2 \\
8.2 \\
8.1 \\
8.1 \\
8.4 \\
8.2 \\
8.3 \\
8.3\end{array}$ & $\begin{array}{l}0.16 \\
0.18 \\
0.15 \\
0.12 \\
0.15 \\
0.15 \\
0.21 \\
0.22\end{array}$ \\
\hline
\end{tabular}


TABLE 5. Estimated Travel Times for Water Movement from Soit Surface to a 43-m-Deep Water Table Using Borehole \#3 Soil Characteristics at Two Recharge Rates

$\frac{\text { Method }}{1 \text { - Averaged Soil Values }}$

2 - Three-Layer System

\begin{tabular}{|c|c|}
\hline$\frac{\text { Travel }}{0.5 \mathrm{~cm} / \mathrm{yr}}$ & $\begin{array}{l}\text { ime, } y r \\
5.0 \mathrm{~cm} / \mathrm{yr}\end{array}$ \\
\hline 710 & 93 \\
\hline 886 & 111 \\
\hline
\end{tabular}

The results presented in Table 5 show that travel times depend on both the estimated recharge rates and the method of calculation. Using the layer data, the travel times were found to be 20 to $25 \%$ longer than when averaged soit characteristics were used, demonstrating the importance of including individual soil layer characteristics in the calculations. In addition to the uncertainty in the recharge rate, the nonuniformity (spatial variability) present at this site makes it impossible to estimate a single travel time for water flow to the water table. A complete analysis of travel times in the vadose zone awaits more definite measurements of recharge rates and a detailed uncertainty analysis of the hydrologic properties of the layered unsaturated sediments. It is anticipated that over the next few years, ongoing research at the Hanford site will provide detailed measurements and analysis that will complement this initial characterization study. 


\section{CONCLUSIONS}

Based on the field and lab data, the following conclusions can be made:

- The sediment profiles at this field site are extremely heterogeneous but, in general, the soils are coarse-textured and drain rapidly.

- The sediment profiles were wet to extended depth $(>25 \mathrm{~m})$, suggesting that drainage is occurring at this site. Rates of drainage were estimated to 1 ie between 0.5 and $5.0 \mathrm{~cm} / \mathrm{yr}$ based on a simplified analysis using exponential relationships for both unsaturated conductivity and water retention characteristics (see Appendix D).

- Estimated travel times for water to move through the unsaturated zone to the water table at this site range from less than 100 years to over 300 years for annual water influx rates of 5.0 to $0.5 \mathrm{~cm} / \mathrm{yr}$, respectively.

- The soil properties determined here will be useful in modeling the transport of water and chemicals (e.g., radionuclides) to the ground water at this site. 


\section{REFERENCES}

Allison, L. E., and C. D. Moodie. 1965. "Carbonate." In Methods of Soil Analysis, Part 2, ed. C. A. Black, Pp. 1389-1392. American Society of Agronomy, Madison, Hisconsin.

ASTM. 1972. "Particle Size Analysis of Soils." Annual Book of ASTM Standards, Part 19, ASTM D 422, American Standard Testing Materials, Phitadelphia, Pennsylvania.

ASTM. 1980. "Laboratory Detemination of Water (Moisture) Content of Soil, Rock, and Soi1-Aggregate Mixtures." Annual Book of ASTM Standards, Part 19, ASTM D 2216, American Standard Testing Materials, Philadelphia, Pennsylvania.

Benson, D. W., J. L. Nel son and G. J. Alkine. 1963. Chemical and Physical Properties of 100 Area Soils. General Electric Co., Richland, Washington.

Bower, C. A., and L. V. Wilcox 1965. "Soluble Salts." In Methods of Soil Aralysis, Part 2, ed. C. A. Black, pp. 935-940. American Society of Agronomy, Madison, Wisconsin.

Brownel1, L. E., J. G. Backer, R. E. Isaacson and D. J. Brown. 1975. Soil Moisture Transport in Arid Site Vadose Zones. ARH-ST-123, Atlantic Ríchfield Hanford, Richland, Washington.

Campbe11, G. S. 1977. An Introduction to Environmental Biophysics. SpringerVerlag, New York, New York.

Chapman, H. D. 1965. "Cation Exchange Capacity." In Methods of Soil Analysis, Part 2. ed. C. A. B1ack, pp. 891-900. American Society of Agronomy, Madison, Wisconsin.

Enfield, C. G., J. J. C. Hsieh and A. W. Warrick. 1973. "Evaluation of Water Flux Above a Deep Water Table Using Thermocouple Psychrometers." Soil Sci. Soc. An. Proc. 37:968-970.

Galley, J. E. 1966. Report of the Committee on Geologic Aspects of Radioactive Waste DisposaT. National Academy of Sciences, National Research CounciT, Washington, D.C.

Isaacson, R. E., and D. J. Brown. 1978. Environmental Assessment Related to Hanford Radioactive Waste Buria1. RHO-SA-35, RockwelT Hanford Operations, Richtand, Washington.

Jones, T. L. 1978. Sediment Moisture Relations: Lysimeter Project 1976-1977 Water Year. RHO-ST-15, Rockwell Hanford Operations, Richland, Washington.

Jones, T. L., and G. W. Gee. 1984. Assessment of Unsaturated Zone Transport for Shallow Land Burial of Radioactive Waste. PNL-4747, Pacific Northwest Laboratory, Richland, Washington. 
Kirkham, R. R., and G. W. Gee. 1984. "Measurement of Unsaturated Fl ow Below the Root-Zone at an Arid Site." Paper presented at the National Water Well Association Conference on Characterization and Monitoring of the Vadose Zone, December 8-10, 1983, National Water Well Association, Las Vegas, Nevada.

K1ute, A. 1965. "Laboratory Measurement of Hydraulic Conductivity of Saturated Soil." In Methods of Soil Analysis, Part 1, ed. C. A. Black, pp. 210222. American Society of Agronomy, Madison, Wisconsin.

McHenry, J. R. 1957. Properties of Soils of the Hanford Project. HW-53218, General Electric Company, Richland, Washington.

National Academy of Sciences. 1957. The Disposal of Radioactive Waste on Land. National Research Council, washington, D.C.

National Academy of Sciences. 1976. The Shallow Land Burial of Low-Level Radioactively Contaminated Solid Waste. National Research Council, Washington, D.C.

National Academy of Sciences. 1978. Radioactive Wastes at the Hanford Reservation: A Technical Review. Committee on Radioactive Waste Management, National Research Council, washington, D.C.

Newcomb, R. C., J. R. Strand and F. J. Frank. 1972. "Geology and Groundwater Characteristics of the Hanford Reservation of the U.S. Atomic Energy Commission." Professional Paper 717, U.S. Geological Survey, Washington, D.C.

Reisenauer, A. E. 1963. "Methods of Solving Problems of Multidimensional Partially Saturated Steady Flow in Soils." J. Geophys. Res, 68(20):57255733.

Richards, L. A. 1965. Physical Condition of Water in Soil. In Methods of Soil Analysis, Part 1, ed. C. A. Black, pp. 128-137. American Society of Agronomy, Madison, Wisconsin.

Routson, R. C., and K. R. Fecht. 1979. Soil (Sediment) Properties of Twelve Hanford Wells with Geologic Interpretation. RH0-CD-82, Rockwell Hanford Operations, Richland, Washington. 
APPENDIX A

DRILLING LOGS 
Wel N Number 1

Driller: Marvin Bultena

Geologist: TL Lijkala

\begin{tabular}{|c|c|c|c|c|}
\hline & $\begin{array}{l}\text { Depth, } \\
\mathrm{m}\end{array}$ & $\begin{array}{c}\text { Sample } \\
\text { Interval, } \\
\text { m }\end{array}$ & $\begin{array}{l}\text { Sample } \\
\text { Number }\end{array}$ & Lithology \\
\hline & 2.1 & $1.3-2.1$ & $1-1$ & $\begin{array}{l}\text { Sand. Brown sand, few small pebbles, } 5 \% \\
\text { granules, } 60 \% \text { very coarse sand, } 30 \% \text { coarse } \\
\text { sand, } 5 \% \text { medium sand, } 1 \text { ow moisture content. }\end{array}$ \\
\hline & 3.8 & $3.1-3.8$ & $1-2$ & $\begin{array}{l}\text { Coarse sand. Brown sand, } 5 \% \text { small pebbles, } \\
20 \% \text { granules, } 50 \% \text { very coarse sand, } 20 \% \\
\text { coarse sand, } 5 \% \text { mediuin sand, low moisture } \\
\text { content. }\end{array}$ \\
\hline & 6.0 & $4.9-6.0$ & $1-3$ & $\begin{array}{l}\text { Fine sand. Change in lithology, contact at } \\
4.6 \mathrm{~m} \text {, dark brown fine sand, } 40 \% \text { medium } \\
\text { sand, } 50 \% \text { fine sand, } 10 \% \text { very fine sand, low } \\
\text { moisture content. }\end{array}$ \\
\hline & 7.2 & $6.6-7.2$ & $1-4$ & $\begin{array}{l}\text { Fine sand, Light brown fine sand, } 20 \% \\
\text { medium sand, } 50 \% \text { fine sand, } 30 \% \text { very fine } \\
\text { sand, tightly compacted, low moisture } \\
\text { content. }\end{array}$ \\
\hline & 9.0 & $8.0-9.0$ & $1-5$ & $\begin{array}{l}\text { Fine sand. Light brown fine sand as above, } \\
\text { thin } 1-2 \text { mm silt lenses, low moisture } \\
\text { content. }\end{array}$ \\
\hline & 10.3 & $9.5-10.3$ & $1-6$ & $\begin{array}{l}\text { Fine sand. Light brown fine sand, } 5 \% \text { medium } \\
\text { sand, } 60 \% \text { fine sand, } 35 \% \text { very fine sand, low } \\
\text { moisture content. }\end{array}$ \\
\hline . & 11.8 & $11.2-11.8$ & $1-7$ & Fine sand. Same as above. \\
\hline & 13.6 & $13.0-13.6$ & $1-8$ & $\begin{array}{l}\text { Fine sand. Brown, slightly coarser than } \\
\text { above, } 50 \% \text { medium sand, } 40 \% \text { fine sand, } 10 \% \\
\text { very fine sand, low moisture content. }\end{array}$ \\
\hline & 15.1 & $13.8-15.1$ & $1-9$ & $\begin{array}{l}\text { Gravel. Brown, sandy, } 5 \% \text { small cobbles, } 20 \% \\
\text { pebbles, } 30 \% \text { granules, } 20 \% \text { very coarse sand, } \\
20 \% \text { coarse sand, } 5 \% \text { medium sand. }\end{array}$ \\
\hline & 17.1 & $16.1-17.1$ & $1-10$ & $\begin{array}{l}\text { Gravel. Light brown sandy, } 5 \% \text { cobbles, } 15 \% \\
\text { pebbles, } 30 \% \text { granules, } 20 \% \text { very coarse sand, } \\
20 \% \text { coarse sand, } 10 \% \text { medium sand, low } \\
\text { moisture content. }\end{array}$ \\
\hline
\end{tabular}


(We)] Number 1 cont)

\begin{tabular}{|c|c|c|c|}
\hline $\begin{array}{l}\text { Depth, } \\
\mathrm{m} \\
\end{array}$ & $\begin{array}{c}\text { Sample } \\
\text { Interval, } \\
\quad\end{array}$ & $\begin{array}{l}\text { Sample } \\
\text { Number } \\
\end{array}$ & Lithology \\
\hline 18.2 & $17.7-18.2$ & $1-11$ & $\begin{array}{l}\text { Gravel. Brown sandy, } 5 \% \text { cobbles, } 15 \% \\
\text { pebbles, } 30 \% \text { granules, } 30 \% \text { very coarse sand, } \\
20 \% \text { coarse sand, low moisture content. }\end{array}$ \\
\hline 20.2 & $19.4-20.2$ & $1-12$ & Gravel. Same as above. \\
\hline 21.5 & $20.8-21.5$ & $1-13$ & $\begin{array}{l}\text { Gravel. Brown sandy, } 10 \% \text { cobbles, } 25 \% \\
\text { pebbles, } 35 \% \text { granules, } 20 \% \text { very coarse sand, } \\
10 \% \text { coarse sand, low moisture content. }\end{array}$ \\
\hline 23.6 & $22.6-23.6$ & $1-14$ & $\begin{array}{l}\text { Gravel. Slight change in lithology, less } \\
\text { coarse material, lack of cobbles, } 5 \% \text { small } \\
\text { pebbles, } 60 \% \text { granules, } 30 \% \text { very coarse sand, } \\
5 \% \text { coarse sand. Some additional water } \\
\text { because of rain down borehole. }\end{array}$ \\
\hline 24.9 & $24.3-24.9$ & $1-15$ & $\begin{array}{l}\text { Coarse sand. Brown, gravelly, } 5 \% \text { granules, } \\
70 \% \text { very coarse sand, } 20 \% \text { coarse sand, } 5 \% \\
\text { medium sand, low moisture content. }\end{array}$ \\
\hline 26.6 & $25.9-26.5$ & $1-16$ & $\begin{array}{l}\text { Coarse sand. Brown, gravelly, } 10 \% \text { granules, } \\
60 \% \text { very coarse sand, } 20 \% \text { coarse sand, } 10 \% \\
\text { medium sand, low moisture content. }\end{array}$ \\
\hline 28.2 & $27.6-28.2$ & $1-17$ & Coarse sand. Sarne as above. \\
\hline 29.9 & $29.2-29.9$ & $1-18$ & $\begin{array}{l}\text { Coarse sand. Slight change in } 1 \text { ithology, } 5 \% \\
\text { granules, } 75 \% \text { very coarse sand, } 15 \% \text { coarse } \\
\text { sand, } 5 \% \text { medium sand, very consistent grain } \\
\text { size, low moisture content. }\end{array}$ \\
\hline 31.5 & $30.8-31.5$ & $1-19$ & $\begin{array}{l}\text { Coarse sand. Pepper-colored sand, very } \\
\text { consistent grain size, } 80 \% \text { very coarse sand, } \\
15 \% \text { coarse sand, } 5 \% \text { medium sand, low } \\
\text { moisture content. }\end{array}$ \\
\hline 33.1 & $32.5-33.1$ & $1-20$ & $\begin{array}{l}\text { Coarse sand. Same as above, with }<1 \% \\
\text { granules. }\end{array}$ \\
\hline 34.9 & $34.1-34.9$ & $1-21$ & Coarse sand. Same as above. \\
\hline
\end{tabular}


(We1? Number 1 cont)

\begin{tabular}{|c|c|c|c|}
\hline $\begin{array}{c}\text { Depth, } \\
\text { in } \\
\end{array}$ & $\begin{array}{l}\text { Sample } \\
\text { Interval, } \\
\mathbf{m}\end{array}$ & $\begin{array}{l}\text { Sample } \\
\text { Number }\end{array}$ & Lithology \\
\hline 36.4 & $35.8-36.4$ & $1-22$ & Coarse sand. Same as above. \\
\hline 38.2 & $37.4-38.2$ & $1-23$ & $\begin{array}{l}\text { Sand and gravel. Change in lithology, brown } \\
\text { sandy gravel, fine brown sand mixed with } \\
\text { granules, } 5 \% \text { small pebbles, } 40 \% \text { granules, } 5 \% \\
\text { very coarse sand, } 10 \% \text { coarse sand, } 10 \% \\
\text { medium sand, } 30 \% \text { fine sand, low moisture } \\
\text { content, contact at } 37.4 \mathrm{~m} \text {. }\end{array}$ \\
\hline 39.7 & $12.8-39.7$ & $1-24$ & $\begin{array}{l}\text { Sand and gravel. Light brown sandy gravel, } \\
5 \% \text { small pebbles, } 40 \% \text { granules, } 20 \% \text { very } \\
\text { coarse sand, } 10 \% \text { coarse sand, } 20 \% \text { medium } \\
\text { sand, } 10 \% \text { fine sand. }\end{array}$ \\
\hline 41.5 & $40.7-41.5$ & $1-25$ & $\begin{array}{l}\text { Sand and gravel. Slight increase in grain } \\
\text { size, broken cobbles up to } 150 \mathrm{~mm}, 5 \% \text { small } \\
\text { cobbles, } 10 \% \text { pebbles, } 40 \% \text { granules, } 10 \% \text { very } \\
\text { coarse sand, } 10 \% \text { coarse sand, } 25 \% \text { medium } \\
\text { sand. }\end{array}$ \\
\hline 41.7 & & & $\begin{array}{l}\text { Core barrel will not advance because of } \\
\text { heavy gravel layer. Hole terminated. }\end{array}$ \\
\hline
\end{tabular}


Well Number 2

Driller: Marvin Bultena

Geologist: TL Liikala, K Oster

\begin{tabular}{|c|c|c|}
\hline $\begin{array}{c}\text { Depth, } \\
\mathrm{m}\end{array}$ & $\begin{array}{c}\text { Sample } \\
\text { Interva?, } \\
\mathbf{m}\end{array}$ & $\begin{array}{l}\text { Sample } \\
\text { Number }\end{array}$ \\
\hline 0.8 & $0.0-0.8$ & $2-1$ \\
\hline
\end{tabular}

$1.6 \quad 0.8-1.6 \quad 2-2$

$3.6 \quad 1.6-3.6 \quad 2-3$

$5.4 \quad 4.6-5.4 \quad 2-4$

$6.9 \quad 6.2-6.9 \quad 2-5$

$8.7 \quad 8.0-8.7 \quad 2-6$

$10.3 \quad 9.7-10.3 \quad 2-7$

$12.0 \quad 11.2-12.0 \quad 2-8$
DRILLING LOG

Date Start $11 / 21 / 83$

Date Finish $12 / 2 / 83$

\section{Lithology}

Soil and gravel. $30 \mathrm{~cm}$ top 5011 , brown sandy grave1, scattered ( $<1 \%$ ) small cobbles, $5 \%$ pebbles, $40 \%$ granules, $20 \%$ coarse sand, $15 \%$ medium sand, contact at $30 \mathrm{~cm}$.

Gravel. Definite increase in grain size, $10 \%$ small cobbles (up to $100 \mathrm{~mm}$ ), $15 \%$ pebbles, $40 \%$ granules, $30 \%$ very coarse sand, $5 \%$ coarse sand, low moisture content.

Fine gravel. Black basaltic sand, few small cobbles, $5 \%$ small pebbles, $20 \%$ granules, $50 \%$ very coarse sand, $25 \%$ coarse sand, slightly moist.

Fine gravel. Same as above, with scattered basalt and quartz cobbles, slightly moist sample.

Coarse sand. Black and brown, slight decrease in overall grain size, $20 \%$ granules, $60 \%$ very coarse sand, $20 \%$ coarse sand, slightly moist.

Sand. Change in lithology at $8.5 \mathrm{~m}$, fine brown sand, very consistent yrain size, $10 \%$ coarse sand, $70 \%$ medium sand, $10 \%$ fine sand, $10 \%$ very fine sand.

Sand. Brown, consistent grain size, $80 \%$ medium sand, $10 \%$ fine sand, $5 \%$ very fine sand, 5\% silt, low moisture content.

Sand. Slight increase in overall grain size, few basalt cobbles present, $5 \%$ granules, $30 \%$ very coarse sand, $40 \%$ coarse sand, $20 \%$ medium sand, $5 \%$ silt, silt lenses (up to $10 \mathrm{~mm}$ thick) low moisture content. 
(Well Number 2 cont)

\begin{tabular}{|c|c|c|c|}
\hline $\begin{array}{c}\text { Depth, } \\
\text { m }\end{array}$ & $\begin{array}{l}\text { Sample } \\
\text { Interval, } \\
\mathrm{m}\end{array}$ & $\begin{array}{l}\text { Sample } \\
\text { Number }\end{array}$ & Lithology \\
\hline 13.6 & $12.8-13.6$ & $2-9$ & $\begin{array}{l}\text { Sand. Brown, consistent grain size, } 30 \% \\
\text { very coarse sand, } 60 \% \text { coarse sand, } 10 \% \\
\text { medium sand, low moisture content. }\end{array}$ \\
\hline 15.3 & $14.4-15.3$ & $2-10$ & $\begin{array}{l}\text { Sand. Brown, contact at } 14.8 \mathrm{~m}, 50 \% \text { very } \\
\text { coarse sand, } 40 \% \text { coarse sand, } 10 \% \text { medium } \\
\text { sand, bits and pieces of broken cobbles, } 10 \mathrm{w} \\
\text { moisture content. }\end{array}$ \\
\hline 16.9 & $16.1-16.9$ & $2-11$ & $\begin{array}{l}\text { Sand. Brown and white, } 5 \% \text { broken cobbles, } \\
5 \% \text { granules, } 60 \% \text { very coarse sand, } 30 \% \\
\text { coarse sand, 10w moisture content. }\end{array}$ \\
\hline 18.5 & $17.7-18.5$ & $2-12$ & $\begin{array}{l}\text { Sand, Brown and white, }<1 \% \text { pebbles, } 10 \% \\
\text { granules, } 60 \% \text { very coarse sand, } 20 \% \text { coarse } \\
\text { sand, } 10 \% \text { medium sand, low moisture content. }\end{array}$ \\
\hline 20.2 & $19.4-20.2$ & $2-13$ & Sand. Same as above. \\
\hline 21.7 & $21.0-21.7$ & $2-14$ & $\begin{array}{l}\text { Sand. Slight decrease in overall grain } \\
\text { size, brown and white, } 5 \% \text { broken pebbles, } 5 \% \\
\text { granules, } 20 \% \text { very coarse sand, } 40 \text { coarse } \\
\text { sand, } 30 \% \text { medium sand, low moisture content. }\end{array}$ \\
\hline 23.3 & $22.6-23.3$ & $2-15$ & Sand. Same as above. \\
\hline 24.9 & $24.3-24.9$ & $2-16$ & Sand. Same as above. \\
\hline 26.6 & $25.9-26.6$ & $2-17$ & $\begin{array}{l}\text { Sand. Brown and white, } 5 \% \text { broken pebbles, } \\
5 \% \text { granules, } 40 \% \text { very coarse sand, } 40 \% \\
\text { coarse sand, } 10 \% \text { medium sand. }\end{array}$ \\
\hline 28.2 & $27.6-28.2$ & $2-18$ & Sand. Same as above. \\
\hline 30.0 & $29.2-30.0$ & $2-19$ & $\begin{array}{l}\text { Gravel. Change in lithology at } 28.5 \mathrm{~m} \text {, } \\
\text { brown fine sand mixed with gravel, } 5 \% \text { broken } \\
\text { cobbles, } 10 \% \text { pebbles, } 40 \% \text { granules, } 5 \% \text { very } \\
\text { coarse sand, } 5 \% \text { coarse sand, } 5 \% \text { med. sand, } \\
30 \% \text { fine sand, low moisture content. }\end{array}$ \\
\hline
\end{tabular}


(Well Number 2 cont)

\begin{tabular}{|c|c|c|c|}
\hline $\begin{array}{c}\text { Depth, } \\
\text { m }\end{array}$ & $\begin{array}{l}\text { Sample } \\
\text { Interval, } \\
\text { m }\end{array}$ & $\begin{array}{l}\text { Sample } \\
\text { Number }\end{array}$ & Lithology \\
\hline 31.3 & $31.0-31.3$ & $2-20$ & $\begin{array}{l}\text { Sand and gravel. Brown sand and gravel, } 5 \% \\
\text { broken cobbles, } 30 \% \text { granules, } 5 \% \text { very coarse } \\
\text { sand, } 5 \% \text { coarse sand } 5 \% \text { med. sand, } 40 \% \text { fine } \\
\text { sand, low moisture content. }\end{array}$ \\
\hline 31.8 & & & Hard gravel, switched over to hard tools. \\
\hline 33.5 & $32.5-33.5$ & $2-21$ & Gravel. \\
\hline 34.8 & $34.0-34.8$ & $2-22$ & Gravel. \\
\hline 36.4 & $35.8-36.4$ & $2-23$ & Gravel. \\
\hline 38.2 & $37.6-38.2$ & $2-24$ & Gravel. \\
\hline 39.7 & $38.5-39.7$ & $2-25$ & Gravel. \\
\hline 41.3 & $40.7-41.3$ & $2-26$ & Gravel. Sone silt. \\
\hline 42.7 & $42.2-42.7$ & $2-27$ & Sand and gravel. Water table at $42.7 \mathrm{~m}$. \\
\hline
\end{tabular}


Wel f Number 3

Driller: Marvin Bultena

Geologist: TL Liikala

\begin{tabular}{|c|c|c|c|c|}
\hline 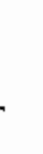 & $\begin{array}{l}\text { Depth, } \\
\text {. }\end{array}$ & $\begin{array}{c}\text { Sample } \\
\text { Interval, } \\
\text { m }\end{array}$ & $\begin{array}{l}\text { Sample } \\
\text { Number }\end{array}$ & Lithology \\
\hline & 1.6 & $0.0-1.6$ & $3-1$ & $\begin{array}{l}\text { Sand. Brown, medium very consistent size, } \\
100 \% \text { medium sand, low moisture content. }\end{array}$ \\
\hline & 3.6 & $3.0-3.6$ & $3-2$ & $\begin{array}{l}\text { Sand. Change in lithology, brown sand mixed } \\
\text { with biack basaltic sand, } 20 \% \text { coarse sand, } \\
80 \% \text { medium sand, low moisture content, } \\
\text { contact at } 3.6 \mathrm{~m} \text {. }\end{array}$ \\
\hline & 5.2 & $4.6-5.2$ & $3-3$ & Sand. Same as above. \\
\hline & 6.9 & $6.2-6.9$ & $3-4$ & $\begin{array}{l}\text { Sand. Black, basaltic, very consistent } \\
\text { grain size, } 90 \% \text { coarse sand, } 10 \% \text { medium } \\
\text { sand, low moisture content. }\end{array}$ \\
\hline & 8.5 & $7.9-8.5$ & $3-5$ & $\begin{array}{l}\text { Sand. Same as above, contains a few } \\
\text { granules. }\end{array}$ \\
\hline & 10.2 & $9.5-10.2$ & $3-6$ & $\begin{array}{l}\text { Sand. Black, basaltic, small pebbles }<1 \% \text {, } \\
5 \% \text { granules, } 30 \% \text { very coarse sand, } 65 \% \\
\text { coarse sand, low moisture content. }\end{array}$ \\
\hline & 11.6 & $11.2-11.6$ & $3-7$ & $\begin{array}{l}\text { Sand. S1ight increase in grain size, black, } \\
\text { basaitic, <1\% pebbles, } 5 \% \text { granules, } 30 \% \text { very } \\
\text { coarse sand, } 65 \% \text { coarse sand, low moisture } \\
\text { content. }\end{array}$ \\
\hline & 13.5 & $12.8-13.5$ & $3-8$ & Sand. Same as above. \\
\hline & 15.1 & $14.4-15.1$ & $3-9$ & Sand. Same as above. \\
\hline : & 16.6 & $16.1-16.6$ & $3-10$ & $\begin{array}{l}\text { Sand. Black basaltic, 5\% granules, } 45 \% \text { very } \\
\text { coarse sand, } 50 \% \text { coarse sand, few silt } \\
\text { lenses, } 1-3 \mathrm{~mm} \text { thick, low moisture content. }\end{array}$ \\
\hline & 18.4 & $17.7-18.4$ & $3-11$ & Sand. Same as above. \\
\hline 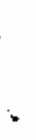 & 20.0 & $19.4-20.0$ & $3-12$ & $\begin{array}{l}\text { Sand. Black basaltic, very consistent grain } \\
\text { size, 50\% very coarse sand, } 50 \% \text { coarse sand, } \\
\text { low moisture content. }\end{array}$ \\
\hline
\end{tabular}

Date Start $12 / 5 / 83$

Date Finish 12/9/83
DRILLING LOG 
(Weil Number 3 cont)

\begin{tabular}{|c|c|c|c|}
\hline $\begin{array}{c}\text { Depth, } \\
\mathrm{m}\end{array}$ & $\begin{array}{c}\text { Sample } \\
\text { Interval, } \\
\quad\end{array}$ & $\begin{array}{l}\text { Sample } \\
\text { Number }\end{array}$ & Lithology \\
\hline 21.7 & $21.0-21.7$ & $3-13$ & $\begin{array}{l}\text { Sand, Change in lithology at } 6.6 \mathrm{~m} \text {, brown, } \\
\text { consistent grain size, } 80 \% \text { coarse sand, } 20 \% \\
\text { medium sand, low moisture content. }\end{array}$ \\
\hline 23.3 & $22.6-23.3$ & $3-14$ & Sand. Same as above. \\
\hline 24.9 & $24.3-24.9$ & $3-15$ & Sand. Same as above. \\
\hline 26.7 & $25.9-26.7$ & $3-16$ & Sand. Same as above. \\
\hline 28.2 & $27.0-28.2$ & $3-17$ & $\begin{array}{l}\text { Sandy gravel. Change in } 1 \text { ithology at } \\
27.7 \mathrm{~m}, 20 \% \text { pebbles, } 30 \% \text { granules, } 40 \% \\
\text { coarse sand, } 10 \% \text { medium sand, low moisture } \\
\text { content. }\end{array}$ \\
\hline 28.9 & & & $\begin{array}{l}\text { Change to hard tools, heavy gravel, no } \\
\text { sample returns in drive barrel. }\end{array}$ \\
\hline 30.2 & $28.0-30.2$ & $3-18$ & Gravel. \\
\hline 31.5 & $30.0-31.5$ & $3-19$ & Gravel. \\
\hline 33.1 & $32.0-33.1$ & $3-20$ & Gravel. \\
\hline 34.8 & $102.0-34.8$ & $3-21$ & Gravel. \\
\hline 36.4 & $35.4-36.4$ & $3-22$ & Gravel. \\
\hline 38.1 & $37.1-38.1$ & $3-23$ & Gravel. \\
\hline 39.7 & $12.8-39.7$ & $3-24$ & Gravel. \\
\hline 41.3 & $40.4-41.3$ & $3-25$ & Gravel. \\
\hline 43. & $42.0-43.0$ & $3-26$ & Gravel. Water table at $42.7 \mathrm{~m}$. \\
\hline
\end{tabular}


Well Number 4

DRILLING LOG

Driller: Marvin Bultena

Geologist: TL Liikala, KR Oster, EJ Jensen

Date Start $12 / 12 / 83$

Date Finish $12 / 16 / 83$

\begin{tabular}{|c|c|c|c|}
\hline $\begin{array}{l}\text { Depth, } \\
\mathrm{m}\end{array}$ & $\begin{array}{c}\text { Sample } \\
\text { Interval, } \\
\mathrm{m}\end{array}$ & $\begin{array}{l}\text { Sample } \\
\text { Number }\end{array}$ & Lithology \\
\hline 1.6 & $0.0-1.6$ & $4-1$ & $\begin{array}{l}\text { Sand. Brown, } 100 \% \text { medium sand, low moisture } \\
\text { content. }\end{array}$ \\
\hline 2.0 & & & Silt. Lenses to $5 \mathrm{~cm}$ thick for $30 \mathrm{~cm}$. \\
\hline 2.6 & & & $\begin{array}{l}\text { Sand. Change in lithology at } 2.6 \mathrm{~m} \text {, black, } \\
80 \% \text { very coarse sand, } 20 \% \text { coarse sand. }\end{array}$ \\
\hline 3.8 & $3.0-3.8$ & $4-2$ & $\begin{array}{l}\text { Sand and gravel. Contact at } 3 \mathrm{~m}, 5 \% \text { small } \\
\text { pebbles, } 15 \% \text { granules, } 50 \% \text { very coarse sand, } \\
30 \% \text { coarse sand, low moisture content. }\end{array}$ \\
\hline 5.1 & $4.4-5.1$ & $4-3$ & $\begin{array}{l}\text { Sand and gravel. Black, } 10 \% \text { small pebbles, } \\
25 \% \text { granules, } 45 \% \text { very coarse sand, } 20 \% \\
\text { coarse sand, silt lenses (up to } 5 \mathrm{~cm}) \text {, low } \\
\text { moisture content. }\end{array}$ \\
\hline 7.2 & $6.2-7.2$ & $4-4$ & $\begin{array}{l}\text { Fine sand. Brown, consistent grain size, } \\
\text { silt lenses, } 70 \% \text { fine sand, } 20 \% \text { very fine } \\
\text { sand, } 10 \% \text { silt, low moisture content. }\end{array}$ \\
\hline 8.9 & $7.9-8.9$ & $4-5$ & $\begin{array}{l}\text { Coarse sand. Black, basaltic, } 70 \% \text { very } \\
\text { coarse sand, } 30 \% \text { coarse sand, low moisture } \\
\text { content. }\end{array}$ \\
\hline 10.2 & $9.2-10.2$ & $4-6$ & Coarse sand. Same as above. \\
\hline 12.3 & $11.2-12.3$ & $4-7$ & Coarse sand. Same as above. \\
\hline 13.8 & $12.8-13.8$ & $4-8$ & $\begin{array}{l}\text { Coarse sand. Slight change in lithology at } \\
13.8 \mathrm{~m},<1 \% \text { small pebbles, } 30 \% \text { very coarse } \\
\text { sand, } 20 \% \text { coarse sand, } 40 \% \text { mediulm sand, } 10 \% \\
\text { fine sand, low moisture content. }\end{array}$ \\
\hline 15.3 & $14.4-15.3$ & $4-9$ & $\begin{array}{l}\text { Coarse sand. Black, basaltic, with some } \\
\text { brown, few small pebbles, } 40 \% \text { very coarse } \\
\text { sand, } 20 \% \text { coarse sand, } 40 \% \text { medium sand, low } \\
\text { moisture content. }\end{array}$ \\
\hline
\end{tabular}


(Wel] Number 4 cont)

\begin{tabular}{|c|c|c|c|c|}
\hline $\begin{array}{c}\text { Depth, } \\
\text { In } \\
\end{array}$ & $\begin{array}{r}\text { Samp } \\
\text { Inter } \\
\end{array}$ & $\begin{array}{l}\text { iple } \\
\text { rval } \\
\end{array}$ & $\begin{array}{l}\text { Sample } \\
\text { Number }\end{array}$ & Lithology \\
\hline 16.7 & $15.9-$ & -16.7 & $4-10$ & Coarse sand. Same as above. \\
\hline 18.4 & 17.7 & -18.4 & $4-11$ & $\begin{array}{l}\text { Sand and Gravel. Brown and black, change in } \\
\text { lithology at } 18 \mathrm{~m} \text {, brown sand and gravel, } 5 \% \\
\text { small pebbles, } 35 \% \text { granules, } 30 \% \text { very coarse } \\
\text { sand, } 20 \% \text { coarse sand, } 10 \% \text { medium sand, low } \\
\text { moisture content. }\end{array}$ \\
\hline 19.8 & 19.4 & -19.8 & $4-12$ & $\begin{array}{l}\text { Sand and gravel. Brown, } 20 \% \text { small pebbles, } \\
20 \% \text { granules, } 10 \% \text { very coarse sand, } 10 \% \\
\text { coarse sand, } 40 \% \text { fine sand, low moisture } \\
\text { content. }\end{array}$ \\
\hline 21.7 & 21.0 & -21.7 & $4-1$ & $\begin{array}{l}\text { Sand and gravel. Brown, } 15 \% \text { medium pebbles, } \\
20 \% \text { granules, } 15 \% \text { very coarse sand, } 10 \% \\
\text { coarse sand, } 40 \% \text { fine sand, low moisture } \\
\text { content. }\end{array}$ \\
\hline 23.3 & $22.6-$ & -23.3 & $4-14$ & $\begin{array}{l}\text { Sand and gravel. Brown, } 10 \% \text { small pebbles, } \\
20 \% \text { granules, } 20 \% \text { very coarse sand, } 15 \% \\
\text { coarse sand, } 35 \% \text { fine sand, } 1 \text { ow moisture } \\
\text { content. }\end{array}$ \\
\hline 25.1 & 24.3 & -25.1 & $4-15$ & Sand and gravel. Same as above. \\
\hline 26.6 & 25.9 & -26.6 & $4-16$ & Sand and gravel. Same as above. \\
\hline 26.6 & & & & $\begin{array}{l}\text { Drive Barrel caught on casing, lost } 5.6 \mathrm{~m} \text { of } \\
\text { hole when casing pulled back. Changed over } \\
\text { to hard tools to recover hole. }\end{array}$ \\
\hline 28.2 & 27.2 & -28.2 & $4-17$ & $\begin{array}{l}\text { Sand and gravel. Further description not } \\
\text { possible because of hard tool use. }\end{array}$ \\
\hline 29.9 & 28.5 & -29.9 & $4-18$ & Sand and gravel. \\
\hline 31.5 & 30.5 & -31.5 & $4-19$ & Sand and gravel. \\
\hline 33.1 & 32.2 & -33.1 & $4-20$ & Sand and gravel. \\
\hline 34.8 & 33.8 & -34.8 & $4-21$ & Sand and gravel. \\
\hline 36.4 & 35.4 & -36.4 & $4-22$ & Sand and gravel. \\
\hline
\end{tabular}




\begin{tabular}{|c|c|c|c|}
\hline $\begin{array}{l}\text { Depth, } \\
\text { m } \\
\end{array}$ & $\begin{array}{c}\text { Sample } \\
\text { Interval, } \\
\text { m }\end{array}$ & $\begin{array}{l}\text { Sample } \\
\text { Number }\end{array}$ & Lithology \\
\hline 38.1 & $37.1-38.1$ & $4-23$ & Gravel. \\
\hline 39.5 & $38.9-39.5$ & $4-24$ & Gravel. \\
\hline 41.3 & $40.4-41.3$ & $4-25$ & Gravel. Water table at $38.4 \mathrm{~m}$. \\
\hline
\end{tabular}


Well Number 5

Oriller: Marvin Bultena

Geologist: TL. Liikala, EJ Jensen
Date Start 12/20/83

Date Finish 12/27/83

\begin{tabular}{|c|c|c|c|}
\hline $\begin{array}{c}\text { Depth, } \\
\mathrm{m}\end{array}$ & $\begin{array}{l}\text { Sample } \\
\text { Interval, } \\
\mathrm{m}\end{array}$ & $\begin{array}{l}\text { Sample } \\
\text { Number }\end{array}$ & Lithology \\
\hline 1.5 & $0.0-1.5$ & $5-1$ & $\begin{array}{l}\text { Top soil and coarse sand, Brown, }<1 \% \text { small } \\
\text { pebbles, } 30 \% \text { granules, } 55 \% \text { very coarse sand, } \\
5 \% \text { medium sand, low moisture content. }\end{array}$ \\
\hline 2.0 & $1.5-2.0$ & $5-2$ & $\begin{array}{l}\text { Very coarse sand. Brown, same as above, } \\
\text { with silt lenses to } 5 \mathrm{cln}, 1 \text { ow moisture } \\
\text { content. }\end{array}$ \\
\hline 2.5 & $2.5-3.3$ & $5-3$ & $\begin{array}{l}\text { Coarse sand. Slight change in lithology at } \\
2 \mathrm{~m} \text {, black and brown, <1\% pebbles, } 10 \% \\
\text { granules, } 40 \% \text { very coarse sand, } 50 \% \text { coarse } \\
\text { sand, low moisture content. }\end{array}$ \\
\hline 3.3 & $2.5-3.3$ & $5-4$ & Coarse sand. Same as above. \\
\hline 3.9 & $3.3-3.9$ & $5-5$ & Coarse sand. Same as above. \\
\hline 4.4 & $3.9-4.4$ & $5-6$ & $\begin{array}{l}\text { Coarse sand, Black, consistent grain size, } \\
5 \% \text { granules, } 45 \% \text { very coarse sand, } 45 \% \\
\text { coarse sand, } 5 \% \text { medium sand, low moisture } \\
\text { content. }\end{array}$ \\
\hline 5.2 & $4.4-5.2$ & $5-7$ & Coarse sand. Sarie as above. \\
\hline 5.7 & $5.2-5.7$ & $5-8$ & Coarse sand. Same as above. \\
\hline 6.6 & $5.7-6.6$ & $5-9$ & Coarse sand. Same as above. \\
\hline 7.2 & $6.6-7.2$ & $5-10$ & $\begin{array}{l}\text { Coarse sand. Slight decrease in grain size, } \\
\text { black, basaltic, } 30 \% \text { very coarse sand, } 70 \% \\
\text { coarse sand, low moisture content. }\end{array}$ \\
\hline 8.2 & $7.2-8.2$ & $5-11$ & Coarse sand. Same as above. \\
\hline 8.7 & $8.2-8.7$ & $5-12$ & $\begin{array}{l}\text { Coarse sand. Slight increase in grain size, } \\
<1 \% \text { small pebbles, } 10 \% \text { granules, } 40 \% \text { very } \\
\text { coarse sand, } 50 \% \text { coarse sand, 10w moisture } \\
\text { content. }\end{array}$ \\
\hline
\end{tabular}


(we11 Number 5 cont)

\begin{tabular}{|c|c|c|c|}
\hline $\begin{array}{c}\text { Depth, } \\
\mathrm{m} \\
\end{array}$ & $\begin{array}{l}\text { Sample } \\
\text { Interval, } \\
\text { m }\end{array}$ & $\begin{array}{l}\text { Sample } \\
\text { Number } \\
\end{array}$ & Lithology \\
\hline 9.5 & $8.7-9.5$ & $5-13$ & $\begin{array}{l}\text { Coarse sand. Black, basaltic, } 10 \% \text { small } \\
\text { pebbles, } 40 \% \text { very coarse sand, } 50 \% \text { coarse } \\
\text { sand, low moisture content. }\end{array}$ \\
\hline 10.3 & $9.5-10.3$ & $5-14$ & Coarse sand. Same as above. \\
\hline 10.8 & $10.3-10.8$ & $5-15$ & Coarse sand. Same as above. \\
\hline 11.6 & $10.8-11.6$ & $5-16$ & $\begin{array}{l}\text { Gravelly sand. Black, basaltic, } 5 \% \text { small } \\
\text { pebbles, } 30 \% \text { granules, } 35 \% \text { very coarse sand, } \\
30 \% \text { coarse sand, low moisture content. }\end{array}$ \\
\hline 12.3 & $11.6-12.3$ & $5-17$ & $\begin{array}{l}\text { Gravelly sand/fine sand. Same as above, } \\
\text { change in } 1 \text { ithology at } 12.1 \mathrm{~m} \text {. Brown, } \\
\text { consistent grain size, 100\% fine sand, low } \\
\text { moisture content. }\end{array}$ \\
\hline 13.0 & $12.3-13.0$ & $5-18$ & $\begin{array}{l}\text { Fine sand. Brown, } 100 \% \text { fine sand, low } \\
\text { moisture content. }\end{array}$ \\
\hline 13.8 & $13.0-13.8$ & $5-19$ & $\begin{array}{l}\text { Sand. Brown, } 50 \% \text { medium sand, } 50 \% \text { fine } \\
\text { sand, low moisture content. }\end{array}$ \\
\hline 14.4 & $13.8-14.4$ & $5-20$ & $\begin{array}{l}\text { Sand. Slight increase in grain size, } 5 \% \\
\text { granules, } 15 \% \text { very coarse sand, } 15 \% \text { coarse } \\
\text { sand, } 30 \% \text { medium sand, } 35 \% \text { fine sand. }\end{array}$ \\
\hline 15.4 & $14.4-15.4$ & $5-21$ & Sand. Same as above. \\
\hline 16.1 & $15.4-16.1$ & $5-22$ & Sand. Same as above. \\
\hline 16.6 & $16.1-16.6$ & $5-23$ & $\begin{array}{l}\text { Coarse sand. Change at } 16.4 \text { m. Black, } \\
\text { basaltic, } 5 \% \text { granules, } 70 \% \text { very coarse sand, } \\
25 \% \text { coarse sand, low moisture content. }\end{array}$ \\
\hline 17.4 & $16.6-17.4$ & $5-24$ & Coarse sand. Same as above. \\
\hline 18.0 & $17.4-18.0$ & $5-25$ & Coarse sand. Same as above. \\
\hline
\end{tabular}


(Well Number 5 cont)

\begin{tabular}{|c|c|c|c|c|}
\hline $\begin{array}{l}\text { Depth, } \\
\text { nn }\end{array}$ & Sam & $\begin{array}{l}\text { mple } \\
\text { erval, } \\
\text { in }\end{array}$ & $\begin{array}{l}\text { Sample } \\
\text { Number }\end{array}$ & Lithology \\
\hline 18.7 & 18.0 & -18.7 & $5-26$ & $\begin{array}{l}\text { Coarse sand. Black, basaltic, consistent } \\
\text { grain size, } 70 \% \text { very coarse sand, } 20 \% \text { coarse } \\
\text { sand, } 10 \% \text { medium sand, low moisture content. }\end{array}$ \\
\hline 19.2 & 18.7 & -19.2 & $5-27$ & Coarse sand. Same as above. \\
\hline 20.0 & 19.2 & -20.0 & $5-28$ & $\begin{array}{l}\text { Coarse sand. Slight increase in grain size, } \\
<1 \% \text { small pebbles, } 10 \% \text { granules, } 70 \% \text { very } \\
\text { coarse sand, } 20 \% \text { coarse sand, low moisture } \\
\text { content. }\end{array}$ \\
\hline 20.7 & 20.0 & -20.7 & $5-29$ & Coarse sand. Same as above. \\
\hline 21.3 & 20.7 & -21.3 & $5-30$ & Coarse sand. Same as above. \\
\hline 21.8 & 21.3 & -21.8 & $5-31$ & Coarse sand. Same as above. \\
\hline 22.5 & 21.8 & -22.5 & $5-32$ & $\begin{array}{l}\text { Coarse sand. Slight increase in grain size, } \\
55 \text { small pebbles, } 10 \% \text { granules, } 70 \% \text { very } \\
\text { coarse sand, } 15 \% \text { coarse sand, low moisture } \\
\text { content. }\end{array}$ \\
\hline 23.1 & 22.5 & -23.1 & $5-33$ & $\begin{array}{l}\text { Coarse sand. Black, basaltic, } 10 \% \text { granules, } \\
70 \% \text { very coarse sand, } 20 \% \text { coarse sand, low } \\
\text { moisture content. }\end{array}$ \\
\hline 24.0 & 23.1 & -24.0 & $5-34$ & Coarse sand. Same as above. \\
\hline 24.6 & 24.0 & -24.6 & $5-35$ & Coarse sand. Same as above. \\
\hline 25.3 & 24.6 & -25.3 & $5-36$ & Coarse sand. Same as above. \\
\hline 25.8 & 25.3 & -25.8 & $5-37$ & Coarse sand. Same as above. \\
\hline 26.2 & 25.8 & -26.2 & $5-38$ & $\begin{array}{l}\text { Coarse sand. S1ight increase in grain size, } \\
10 \% \text { pebbles, } 10 \% \text { granules, } 60 \% \text { very coarse } \\
\text { sand, } 20 \% \text { coarse sand, } 10 \text { moisture content. }\end{array}$ \\
\hline 26.9 & 26.2 & -26.9 & $5-39$ & $\begin{array}{l}\text { Coarse sand. Black and brown, } 5 \% \text { small } \\
\text { pebbles, } 10 \% \text { granules, } 60 \% \text { very coarse sand, } \\
25 \% \text { coarse sand, low moisture content. }\end{array}$ \\
\hline
\end{tabular}


(We) Number 5 cont)

\begin{tabular}{|c|c|c|c|}
\hline $\begin{array}{c}\text { Depth, } \\
\text { m }\end{array}$ & $\begin{array}{c}\text { Sample } \\
\text { Interval, } \\
\mathrm{m}\end{array}$ & $\begin{array}{l}\text { Sample } \\
\text { Number } \\
\end{array}$ & Lithology \\
\hline 27.4 & $26.9-27.4$ & $5-40$ & $\begin{array}{l}\text { Coarse sand, Brown and black, } 5 \% \text { small } \\
\text { pebbles, } 10 \% \text { granules, } 60 \% \text { very coarse sand, } \\
25 \% \text { coarse sand, low moisture content. }\end{array}$ \\
\hline 27.9 & $27.4-27.9$ & $5-41$ & Coarse sand. Same as above. \\
\hline 28.5 & $27.9-28.5$ & $5-42$ & Coarse sand. Same as above. \\
\hline 29.2 & $28.5-29.2$ & $5-43$ & $\begin{array}{l}\text { Coarse sand. Slight increase in grain size, } \\
10 \% \text { small pebbles, } 20 \% \text { granules, } 60 \% \text { very } \\
\text { coarse sand, } 10 \% \text { coarse sand, low moisture } \\
\text { content. }\end{array}$ \\
\hline 29.7 & $29.2-29.7$ & $5-44$ & $\begin{array}{l}\text { Sandy gravel. Change in lithology at } 29.2 \\
\text { m. Brown, } 40 \% \text { well-rounded small pebbles, } \\
20 \% \text { granules, } 40 \% \text { very coarse sand, low } \\
\text { moisture content. }\end{array}$ \\
\hline 30.2 & $29.7-30.2$ & $5-45$ & $\begin{array}{l}\text { Sandy gravel. Brown, } 30 \% \text { well-rounded } \\
\text { pebbles, 30\% granules, } 35 \% \text { very coarse sand, } \\
\text { low moisture content. }\end{array}$ \\
\hline 30.7 & $30.2-30.7$ & $5-46$ & $\begin{array}{l}\text { Sandy gravel. Brown, } 15 \% \text { pebbles, } 40 \% \\
\text { granules, } 35 \% \text { very coarse sand, } 10 \% \text { coarse } \\
\text { sand, low moisture content. }\end{array}$ \\
\hline 31.2 & $30.7-31.2$ & $5-47$ & $\begin{array}{l}\text { Sandy gravel. Same as above. Change to } \\
\text { hard tools, no sample return. }\end{array}$ \\
\hline 32.5 & $31.2-32.5$ & $5-48$ & Gravel. \\
\hline 33.6 & $32.5-33.6$ & $5-49$ & Gravel. \\
\hline 34.3 & $33.5-34.3$ & $5-50$ & Gravel. \\
\hline 35.4 & $34.3-35.4$ & $5-51$ & Gravel. \\
\hline 36.4 & $35.4-36.4$ & $5-52$ & Gravel. \\
\hline 37.1 & $36.4-37.1$ & $5-53$ & Gravel. \\
\hline 38.1 & $37.1-38.1$ & $5-54$ & Gravel. \\
\hline 38.9 & $38.1-38.9$ & $5-55$ & Gravel. \\
\hline
\end{tabular}


(well Number 5 cont)

\begin{tabular}{|c|c|c|c|}
\hline $\begin{array}{c}\text { Depth, } \\
\text { m }\end{array}$ & $\begin{array}{c}\text { Sample } \\
\text { Interval, } \\
m\end{array}$ & $\begin{array}{l}\text { Sample } \\
\text { Number }\end{array}$ & Lithology \\
\hline 39.7 & $38.9-39.7$ & $5-56$ & Gravel. \\
\hline 40.2 & & & Bottom of hole. \\
\hline
\end{tabular}


APPENDIX B

PARTICLE-SIZE OISTRIBUTION PLOTS FOR SELECTED CORE SAMPLES FROM FIVE WELLS NEAR THE HANFORD WYE BARRICADE

Note: Numbers at the top of the piots correspond to well numbers and depths as described in Appendix A. Ordinate of each curve is the percentage of the sample less than the particle diameter $x$. 


\section{SAMPLE $1-26$}

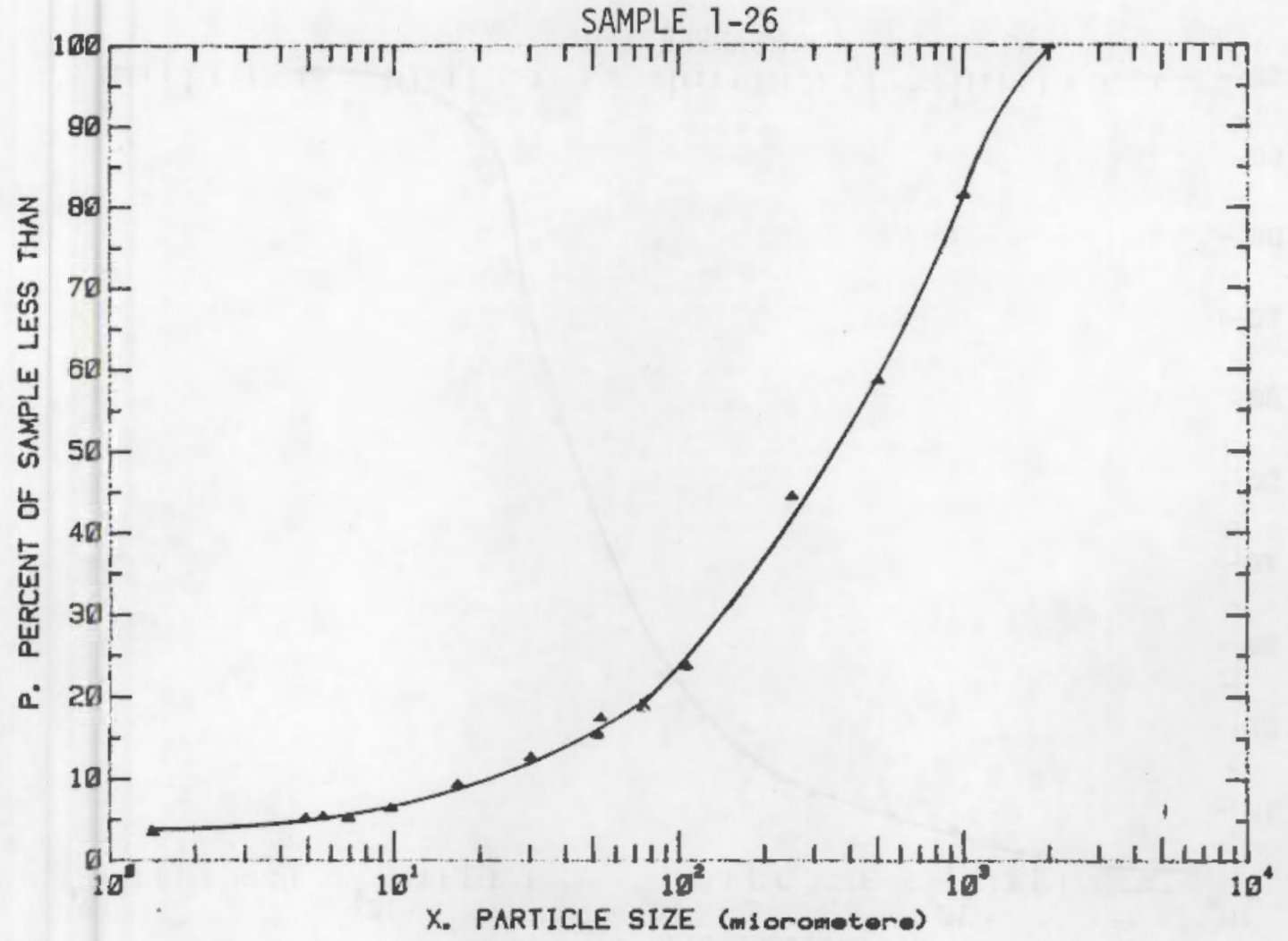

SAMPLE $7-2$

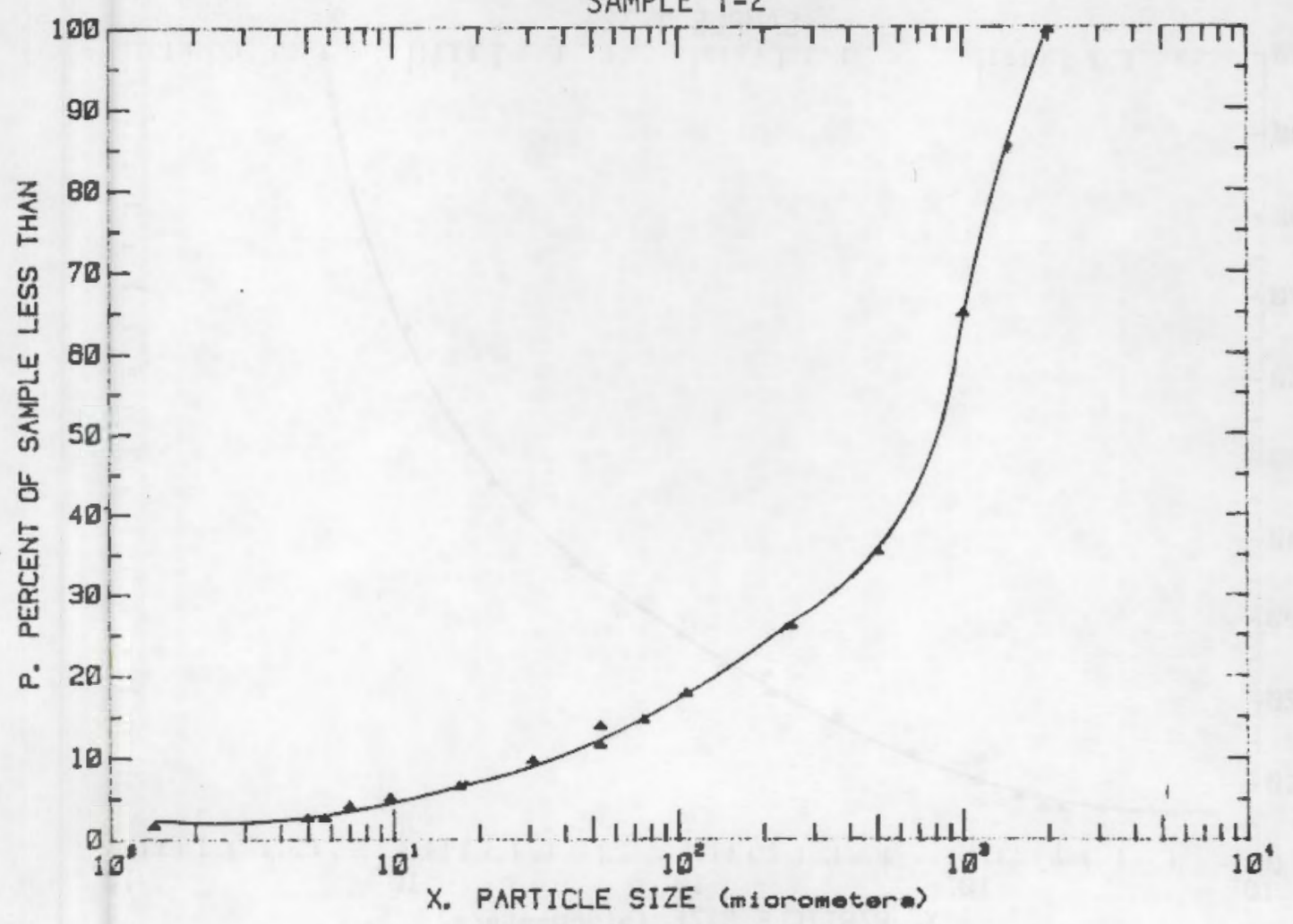

B. 1 
SAMPLE 1-8

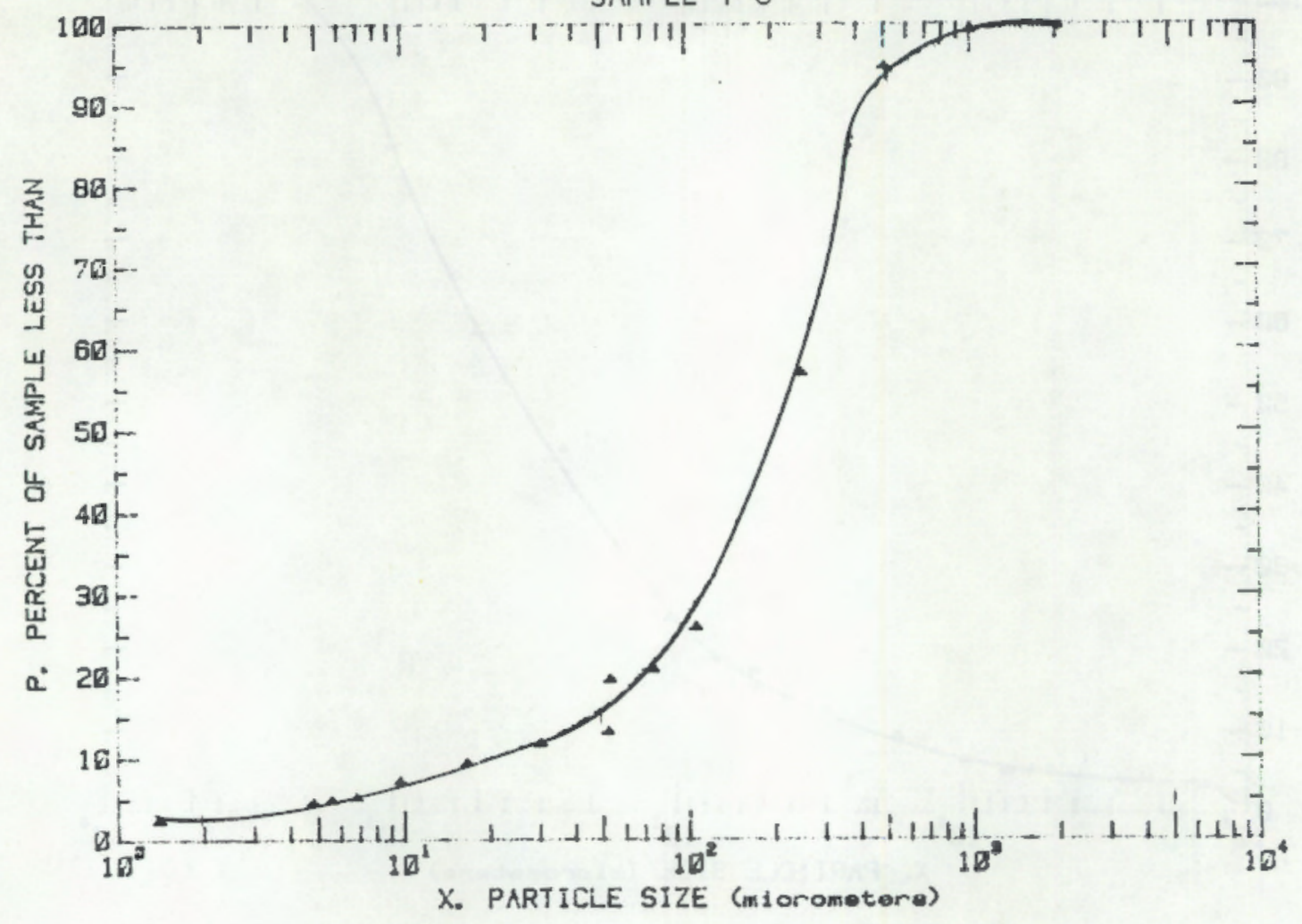

SAMPLE $1-12$

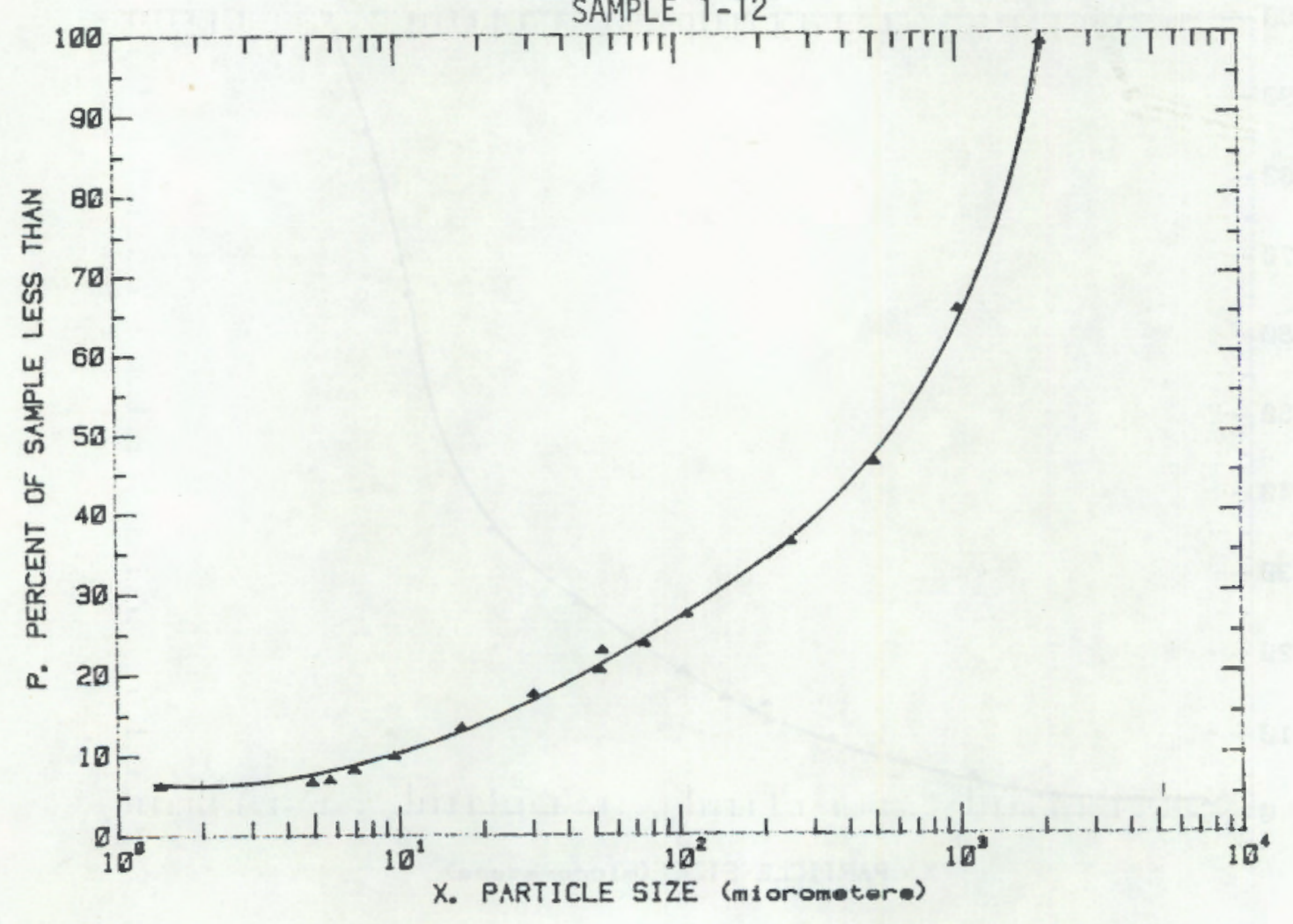


SAMPLE 1-16

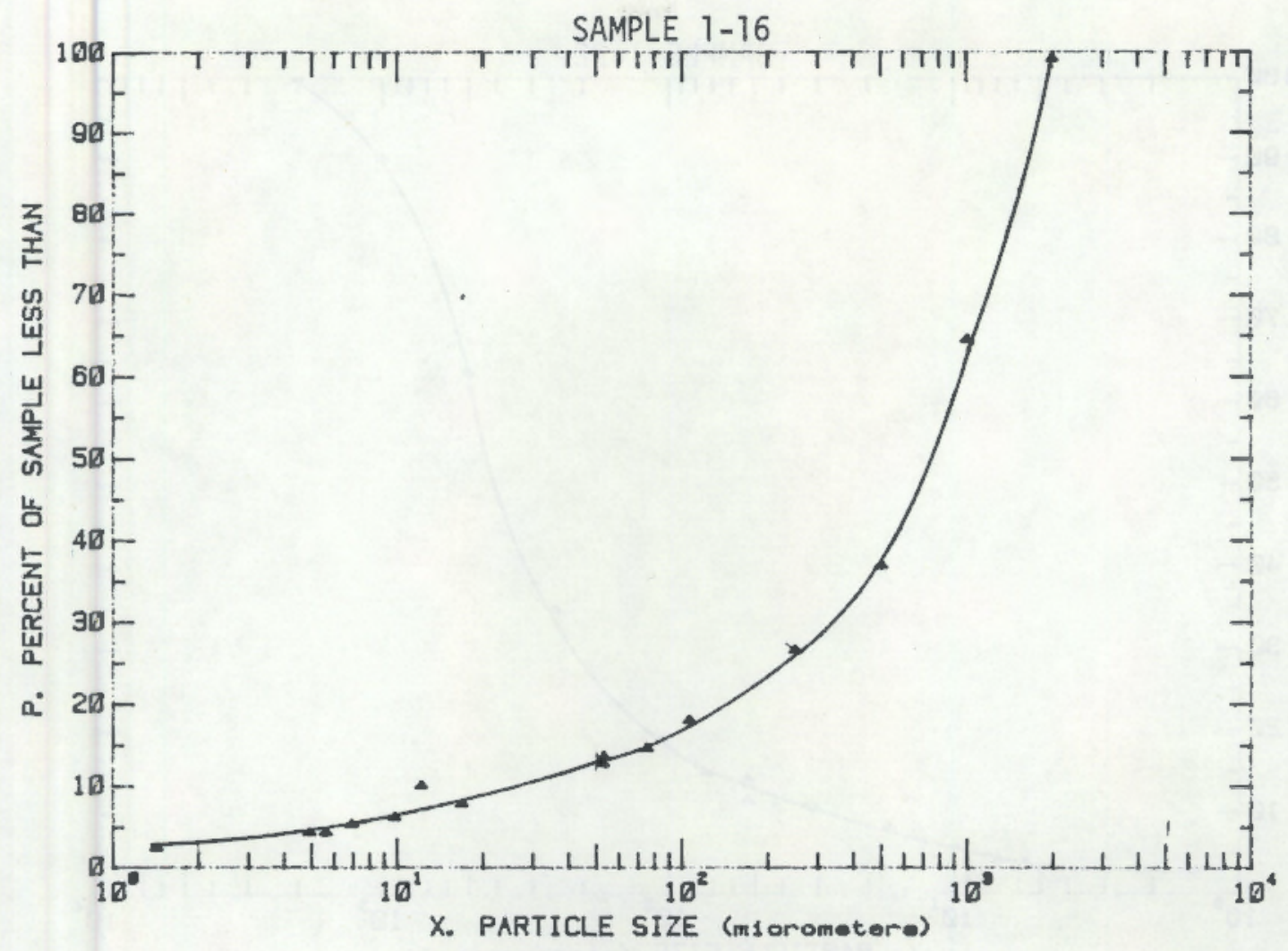

SAMPLE 1-19

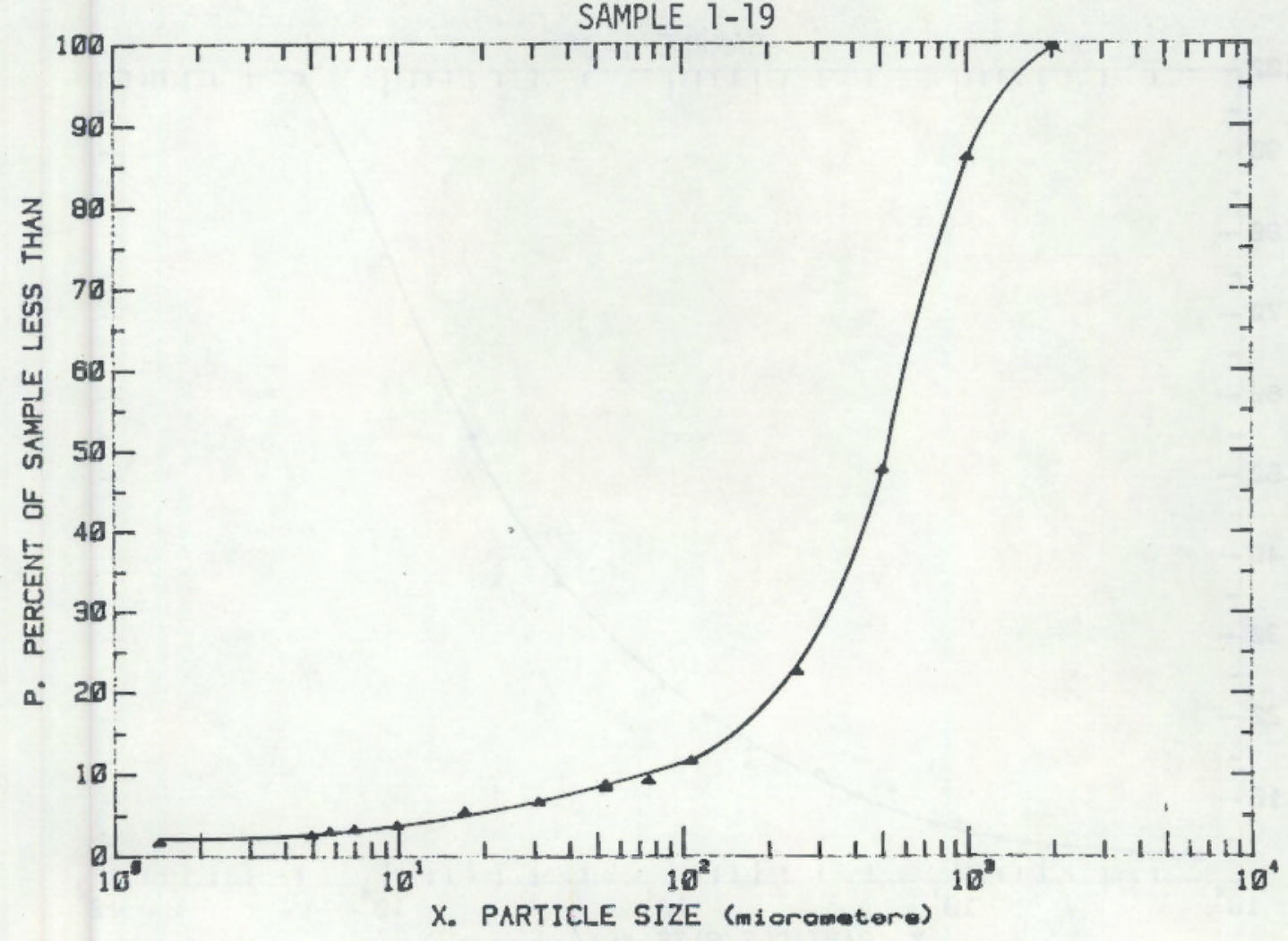

3. 3 

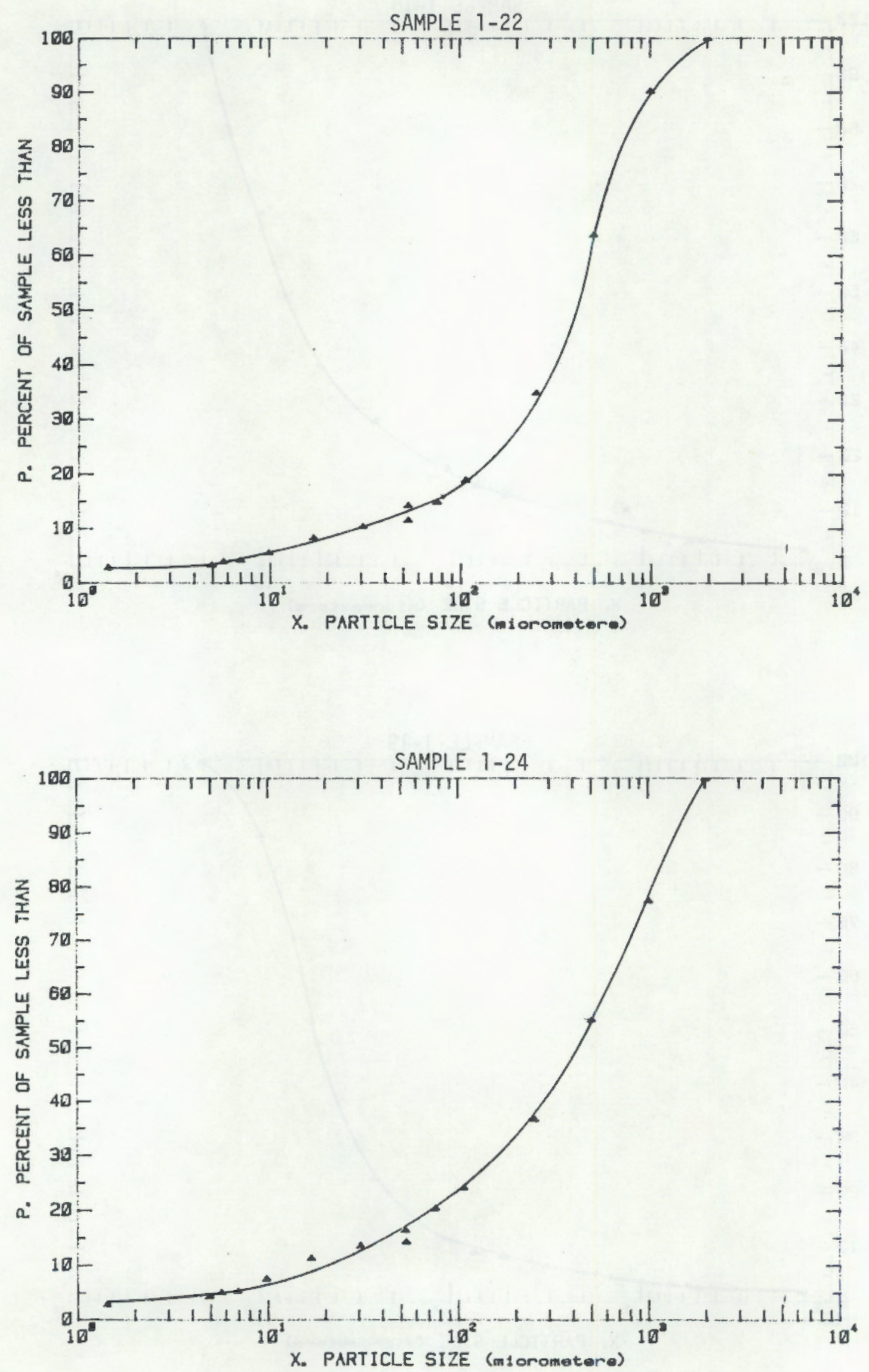

B. 4 
SAMPLE 2-1

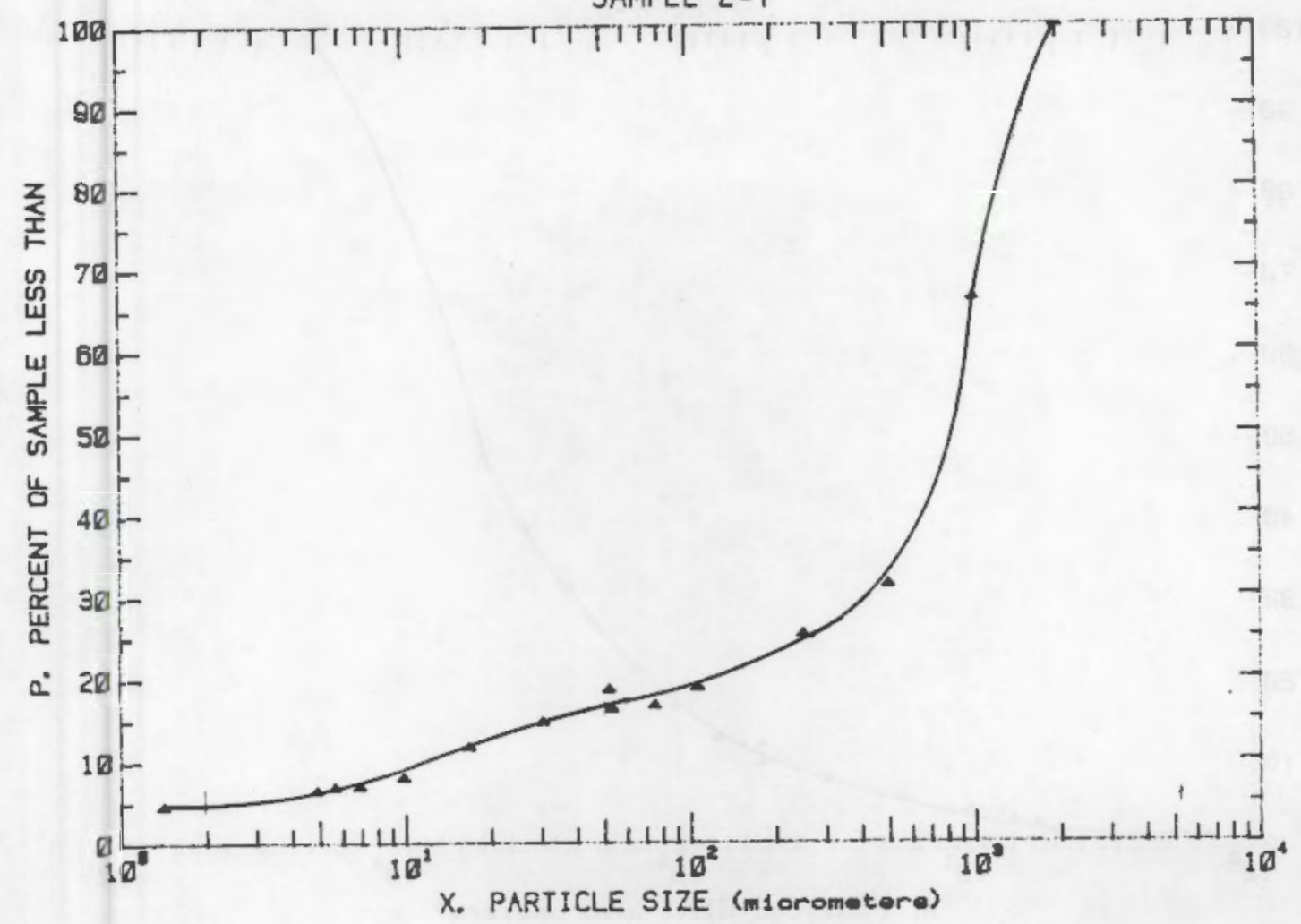

SAMPLE 2-4

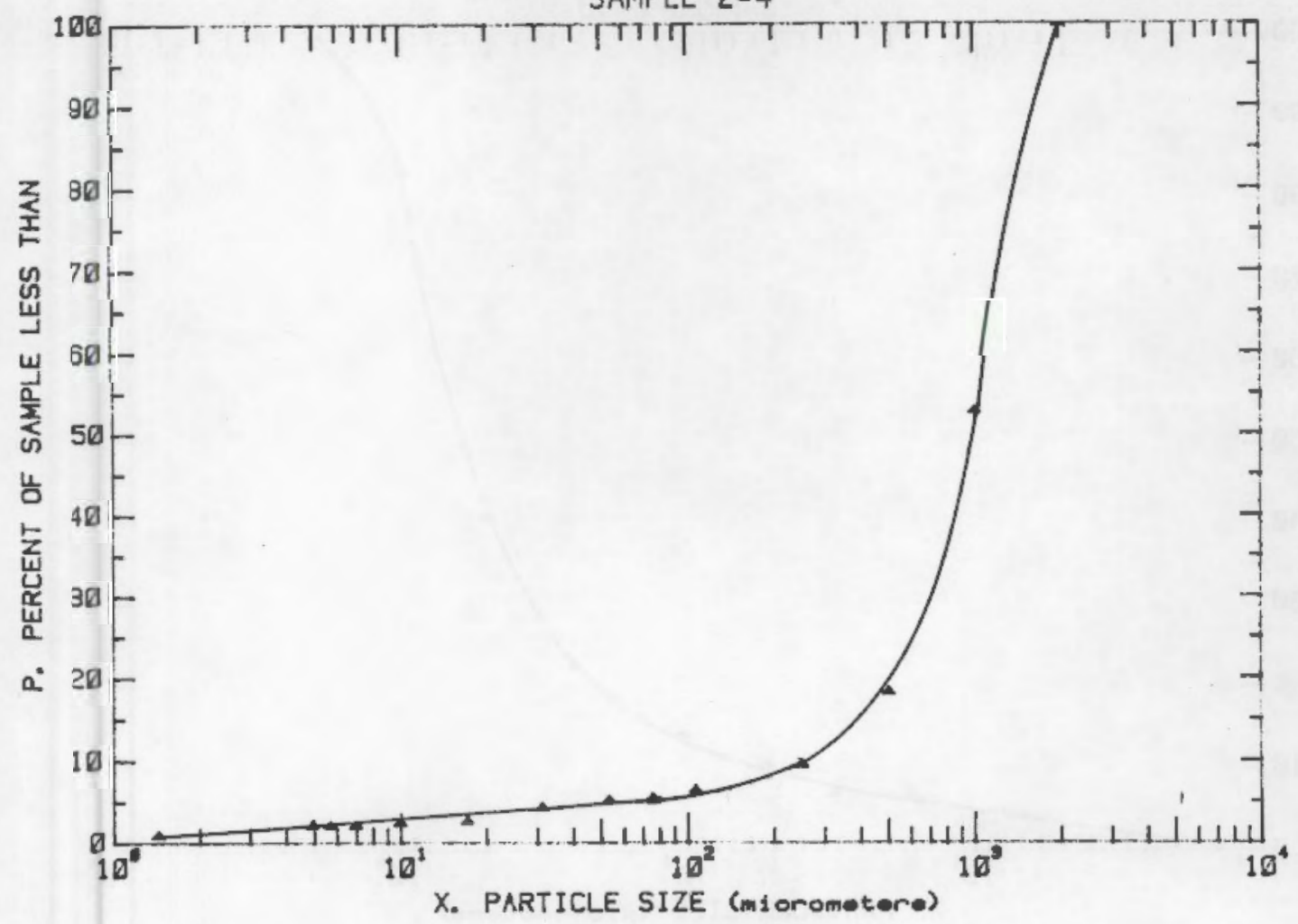

B. 5 
SAMPLE 2-6

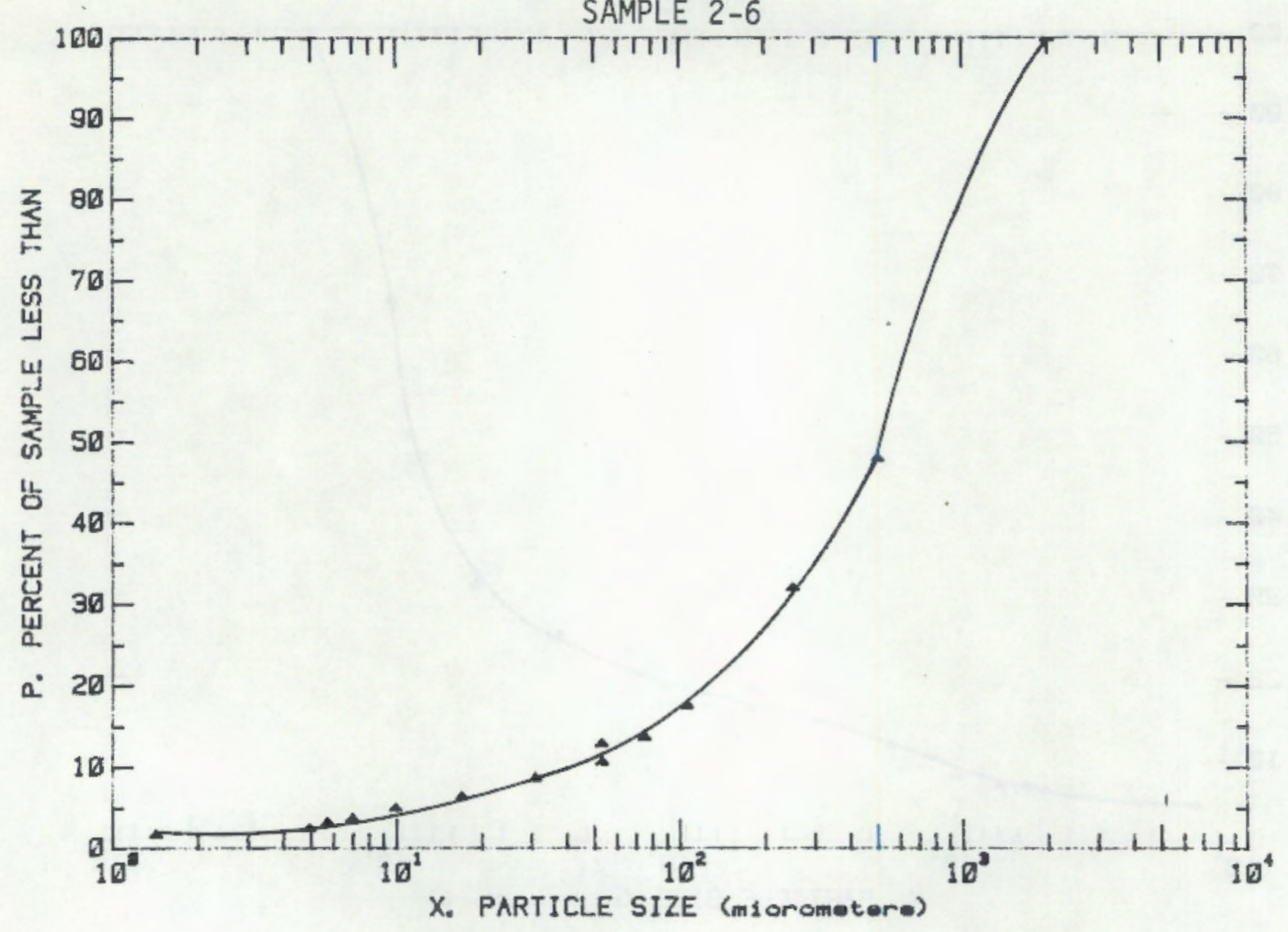

SAMPLE 2-10

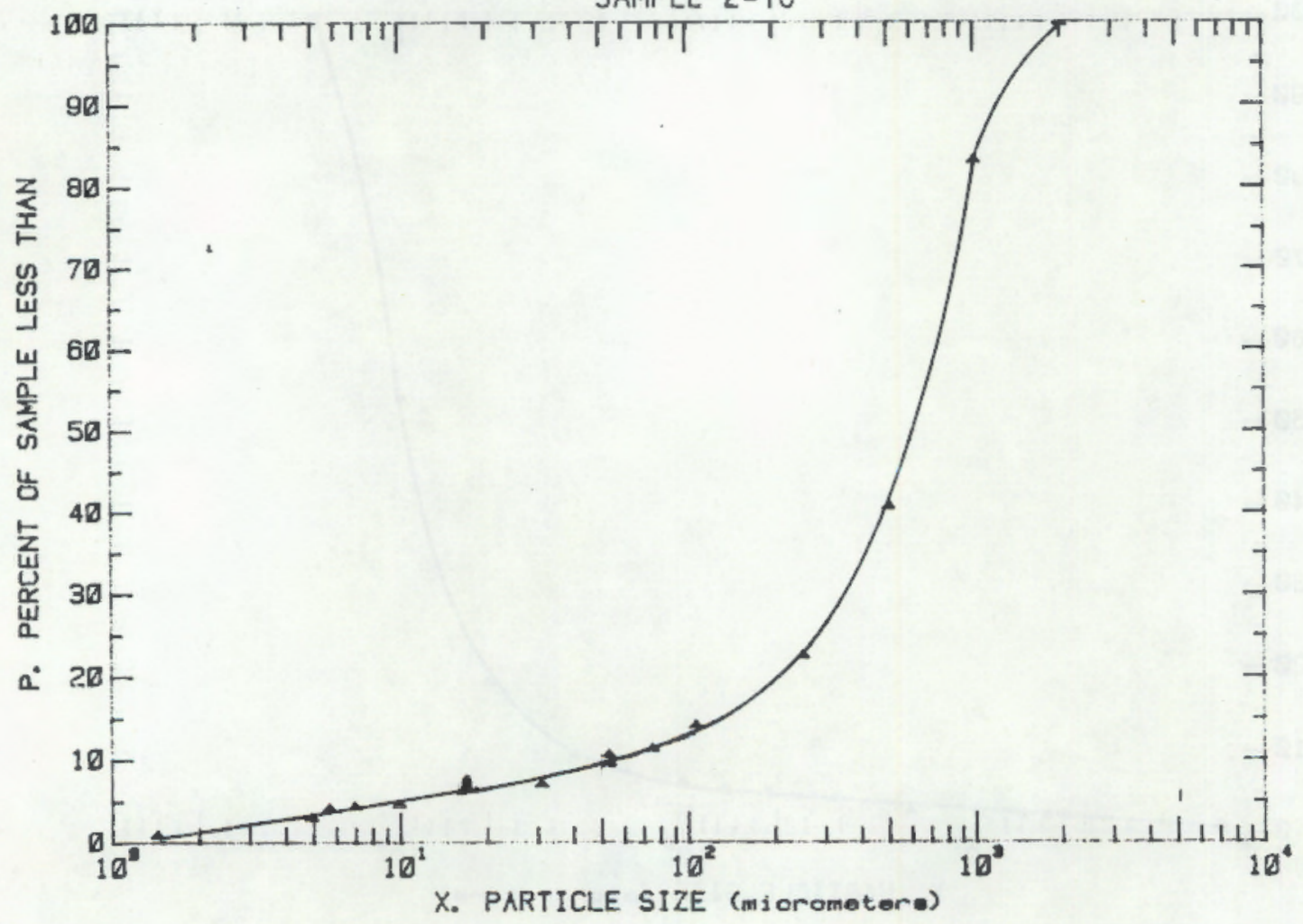

8.6 
SAMPLE 2-16

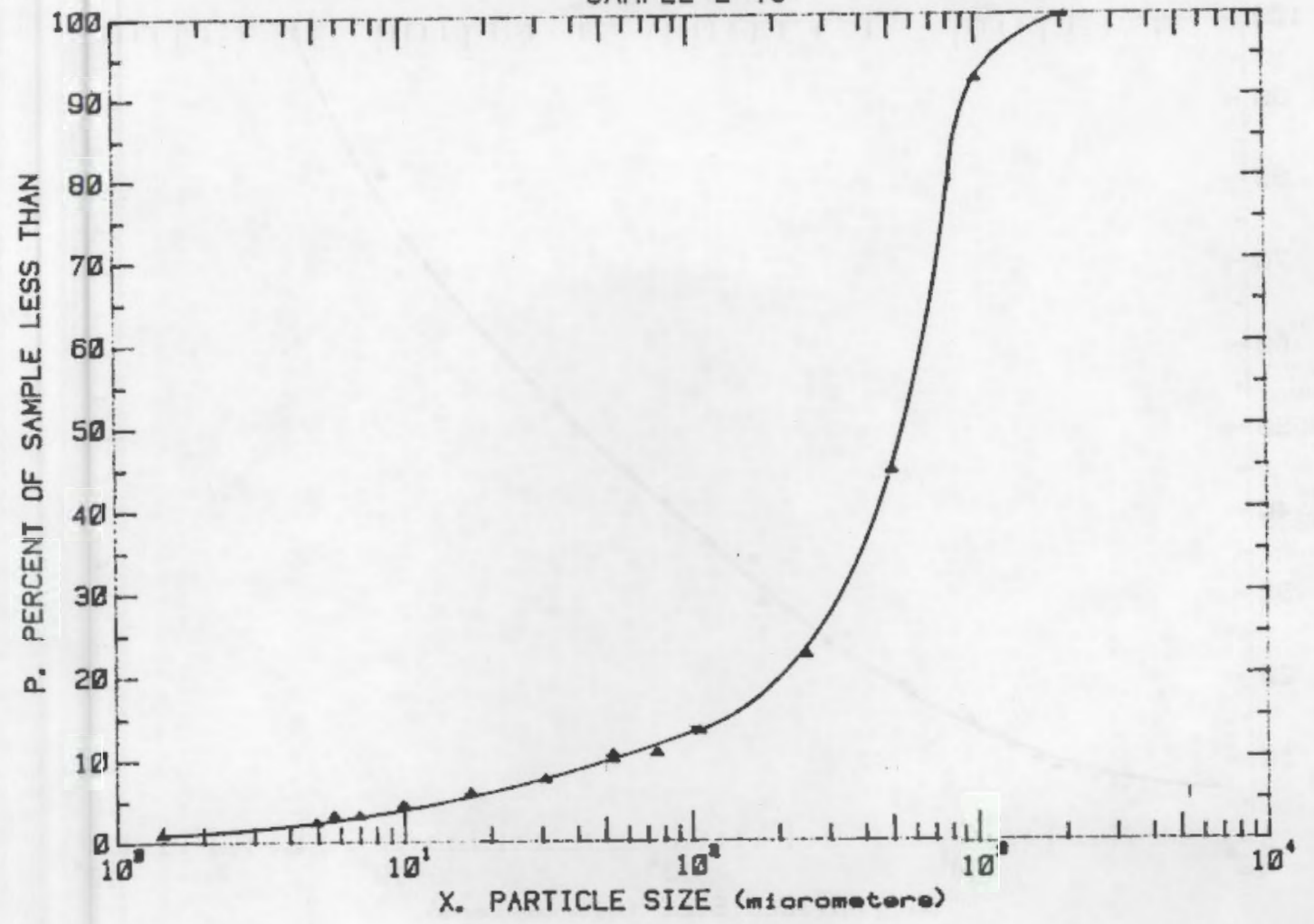

SAMPLE 2-19

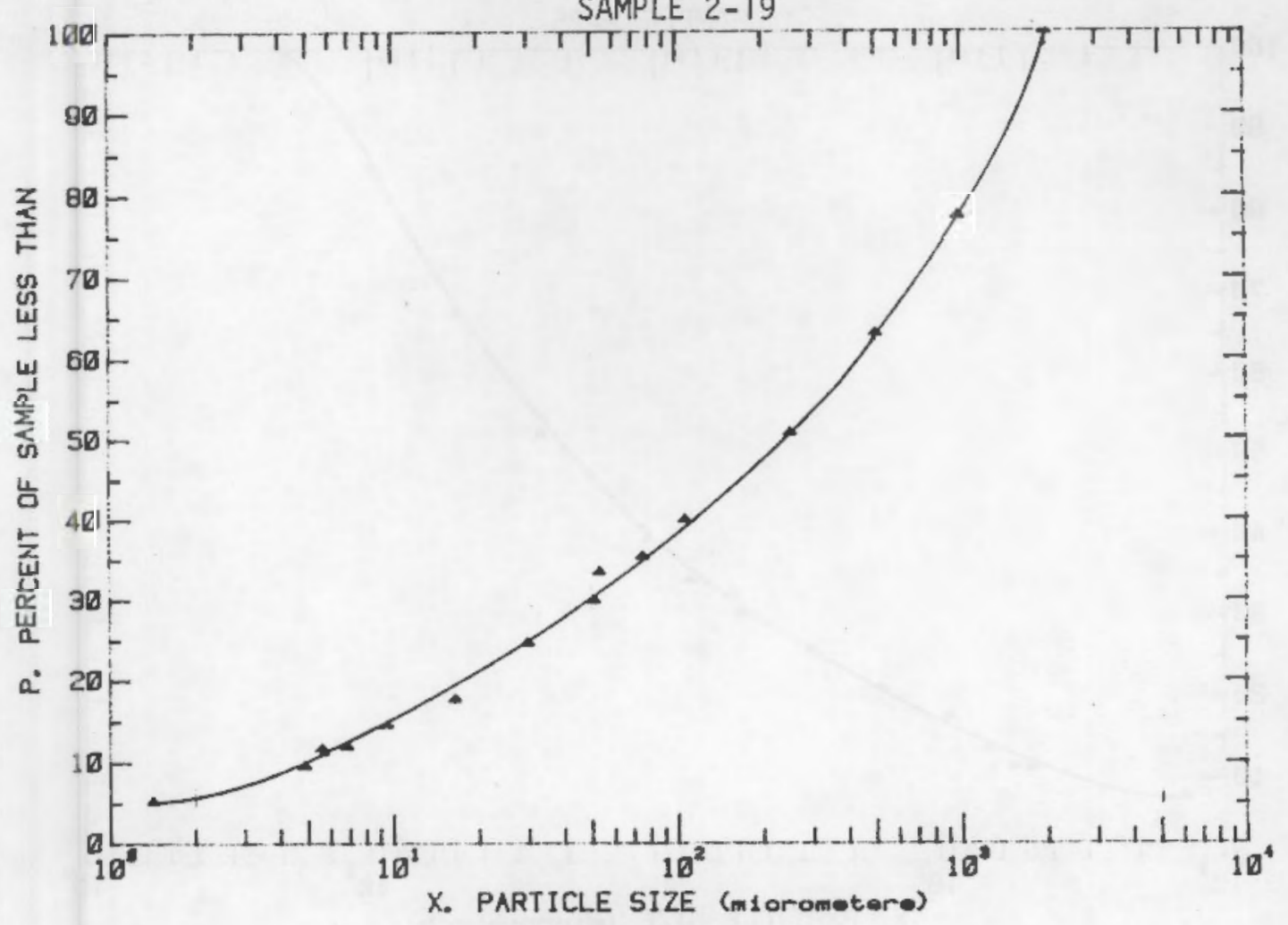


SAMPLE 2-22
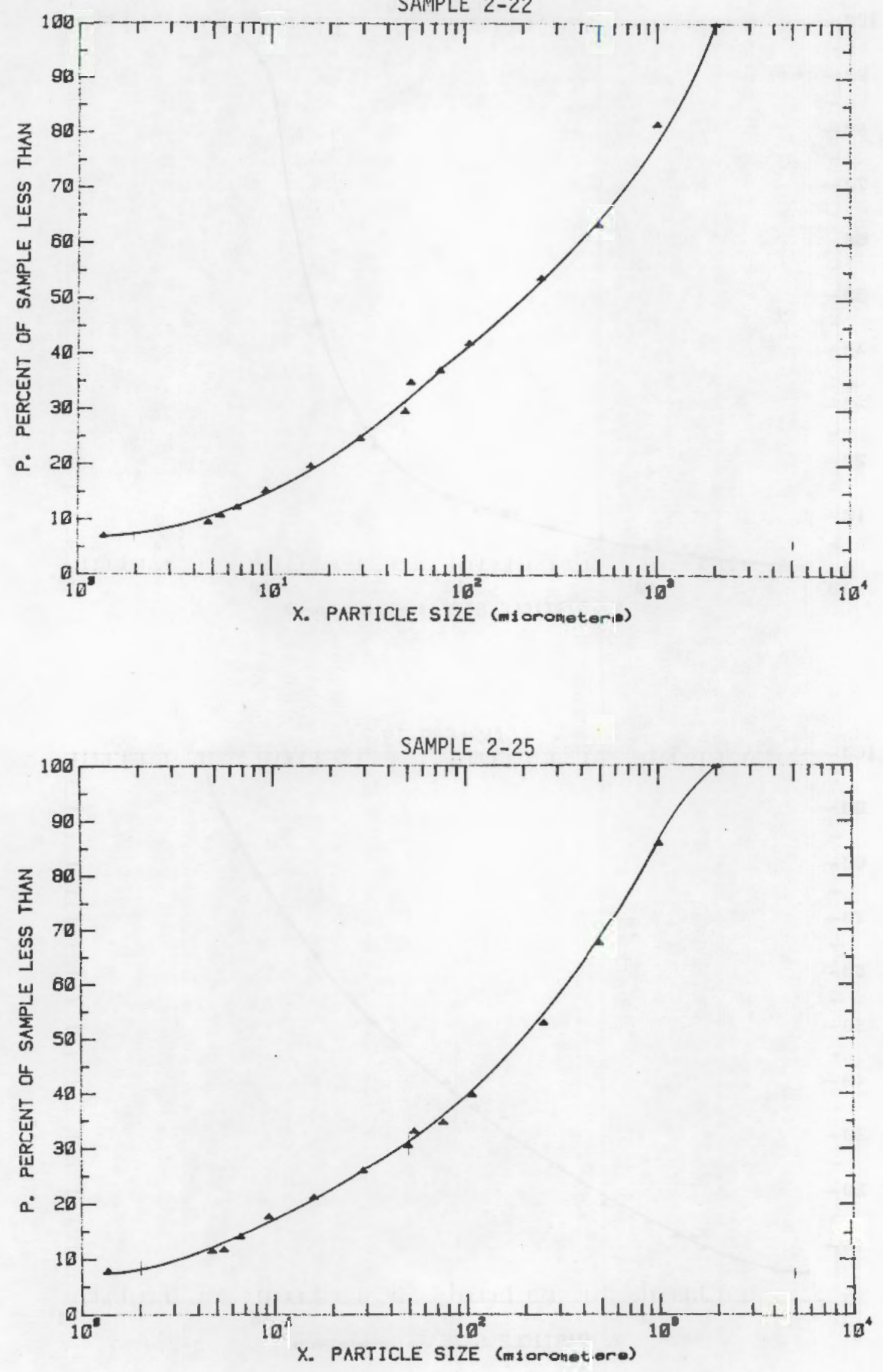

B. 8 
SAMPLE 3-1

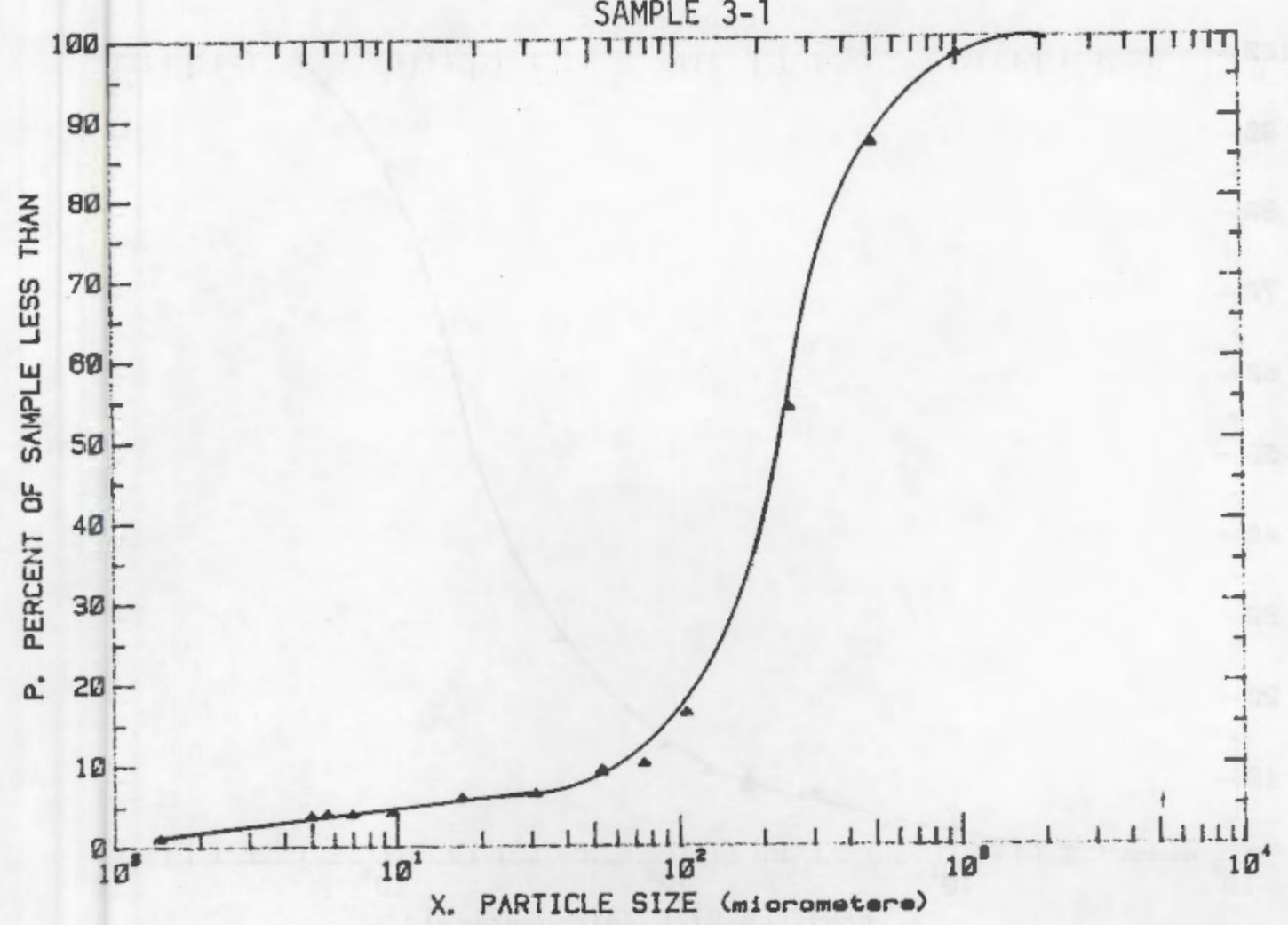

\section{SAMPLE 3-3}

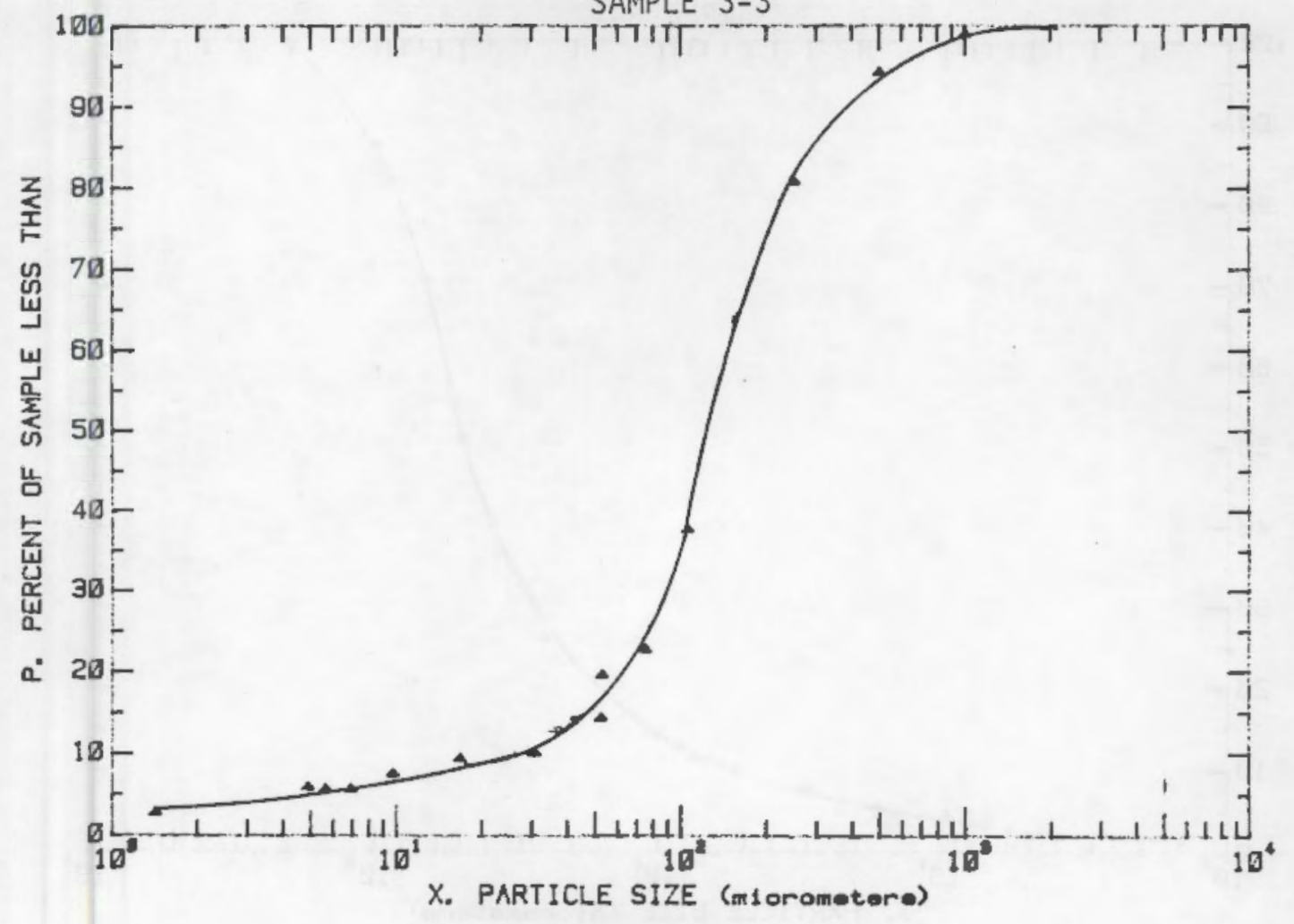

B. 9 
SAMPLE 3-6

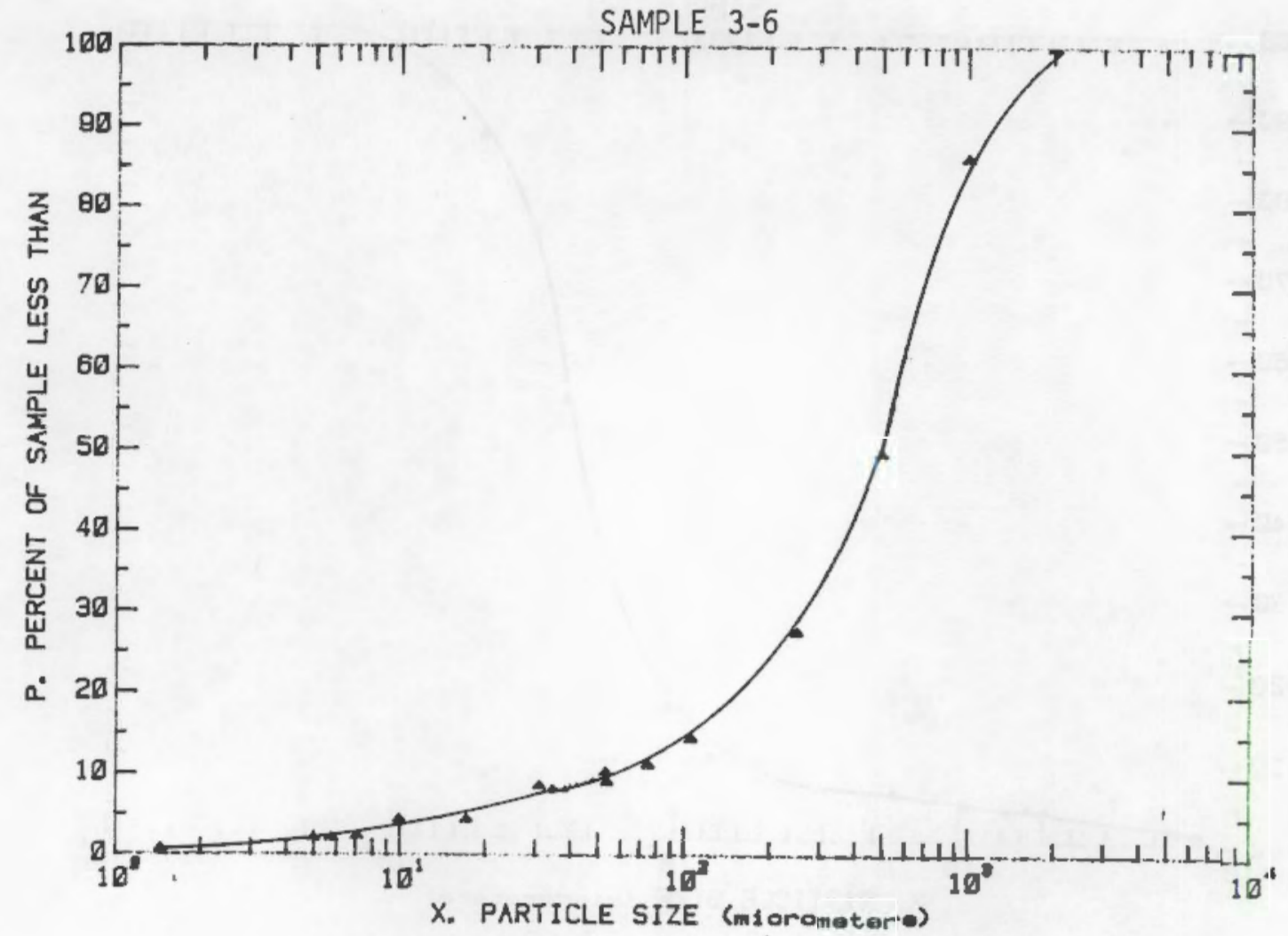

SAMPLE $3-12$

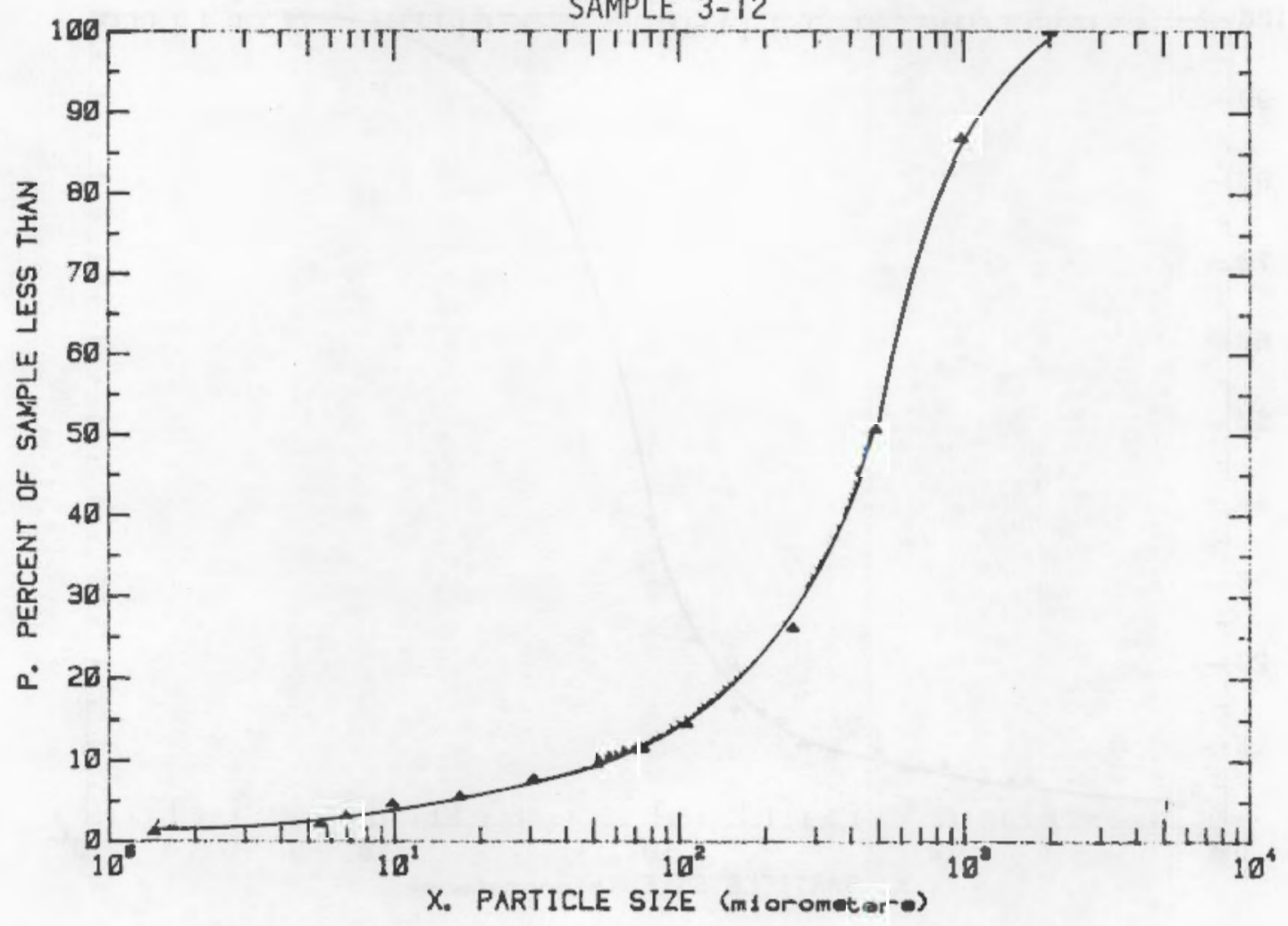

B. 10 

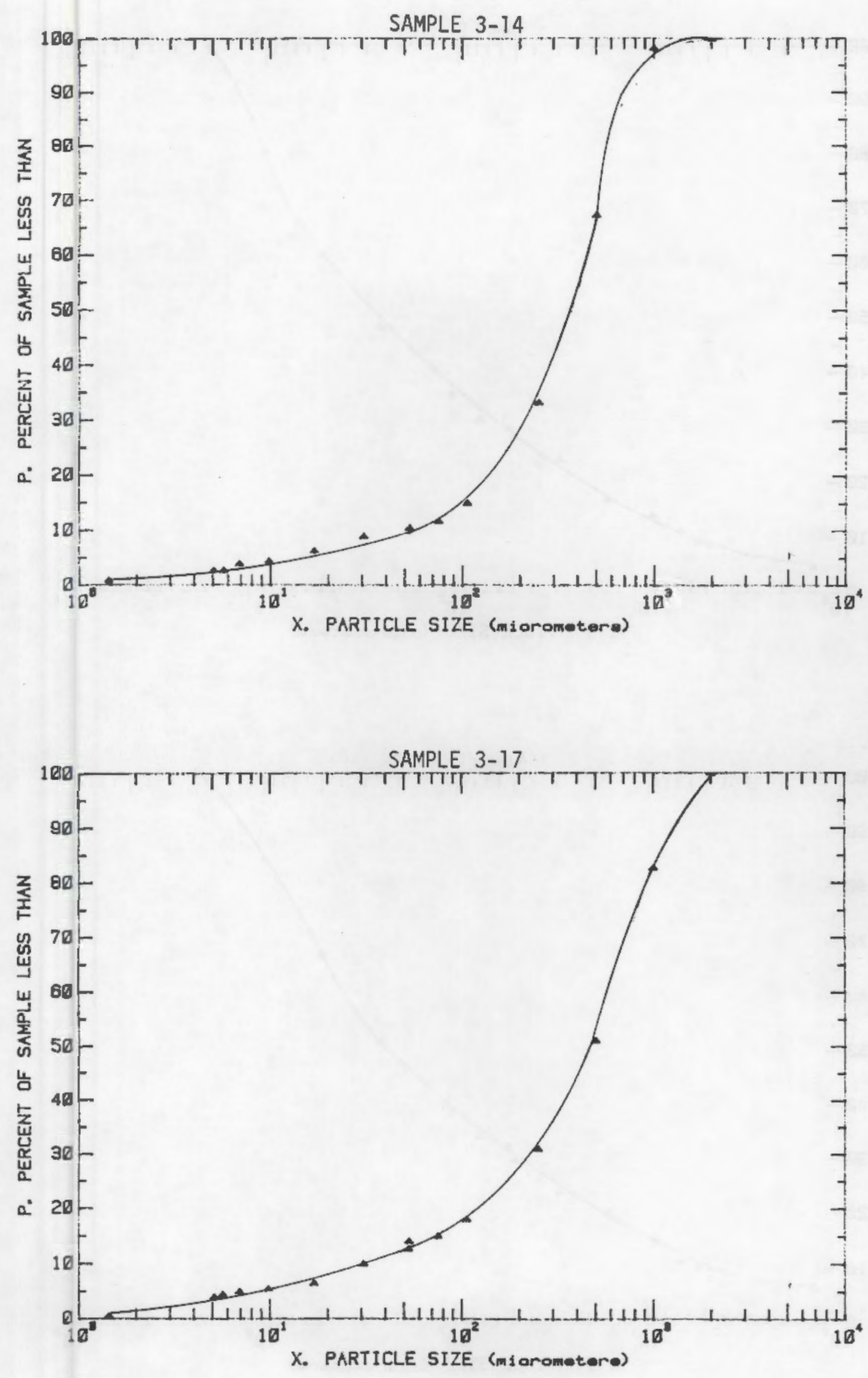

B. 11 
SAMPLE 3-21

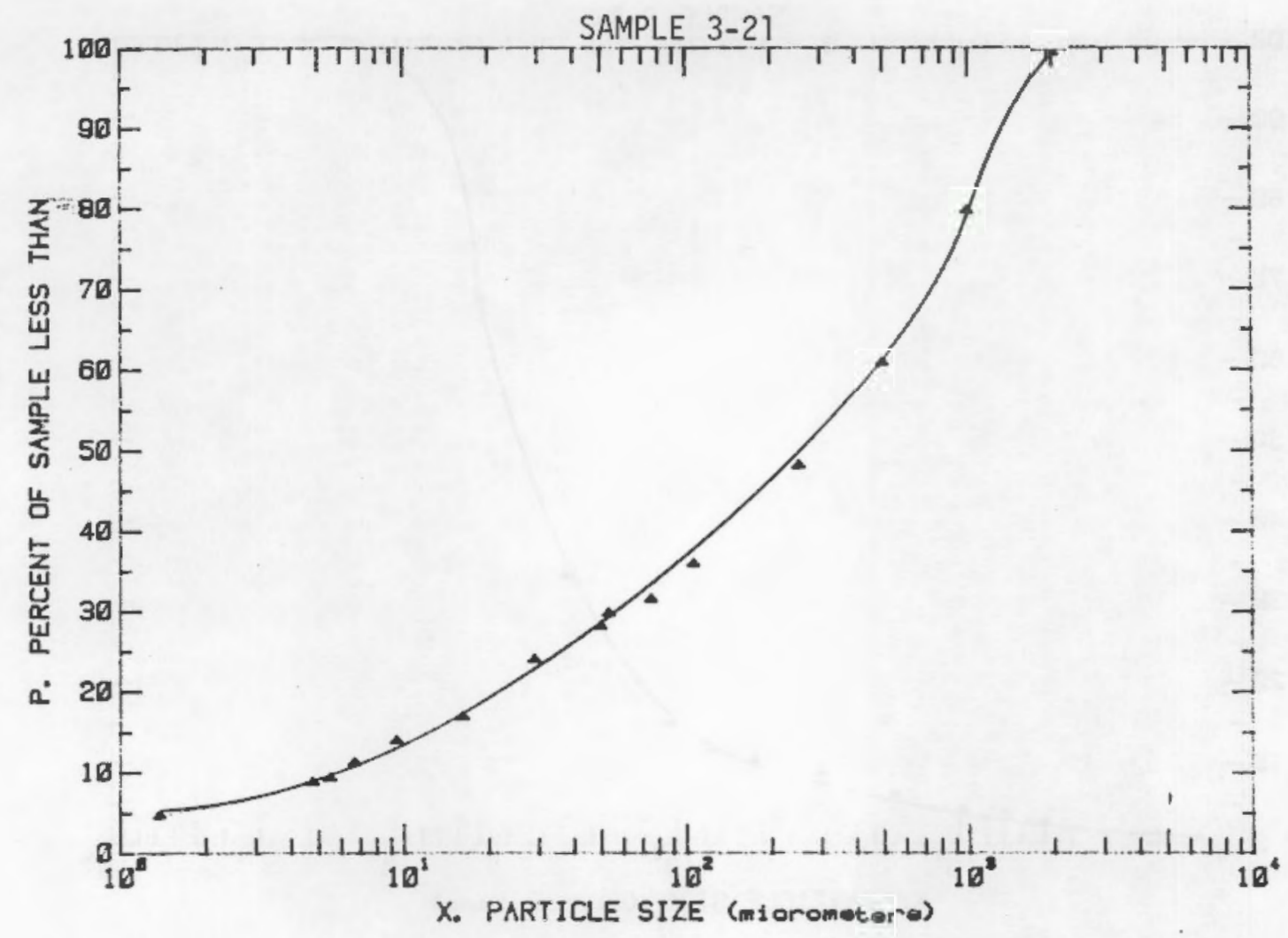

SAMPLE 3-25

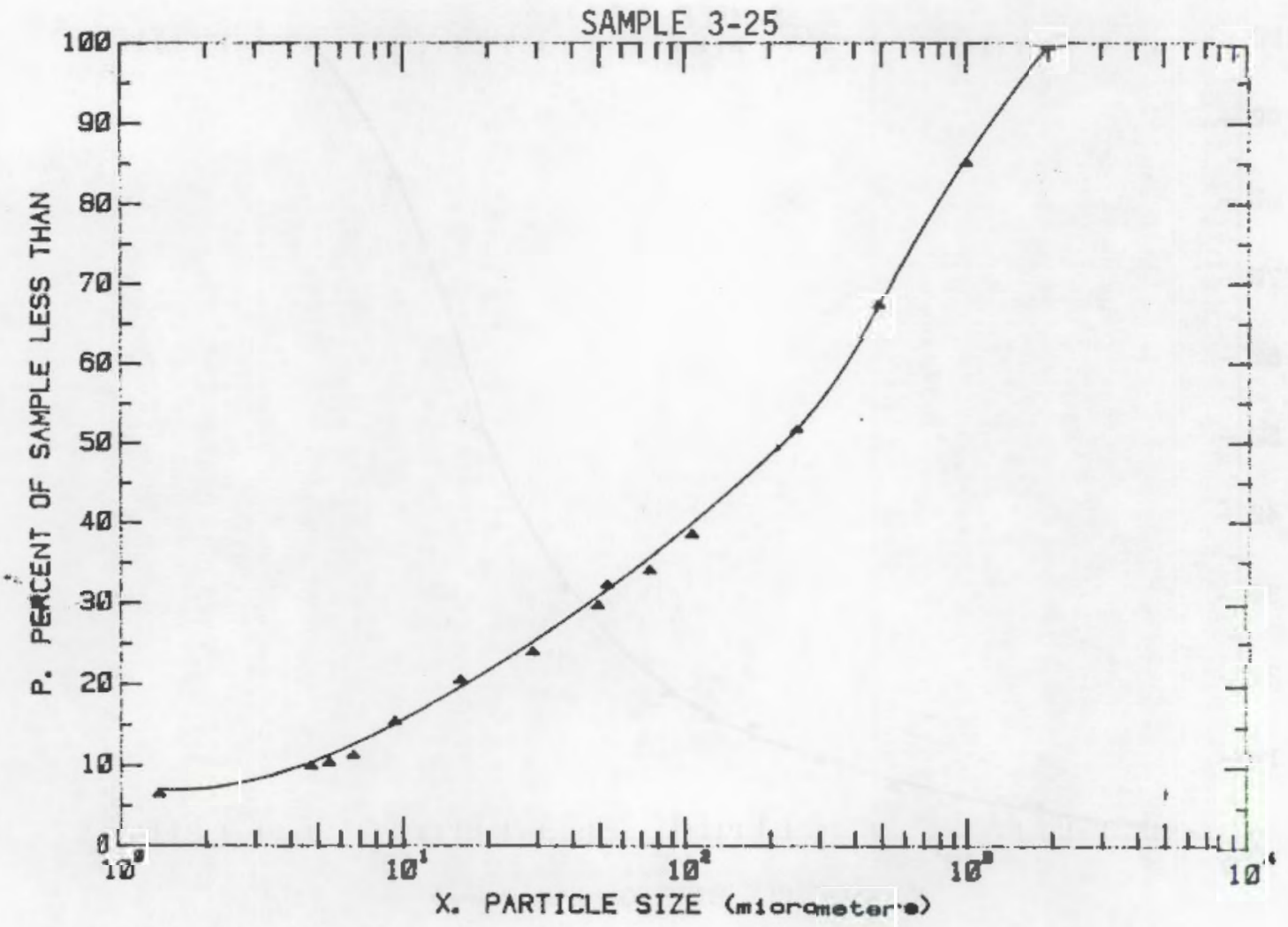

B. 12 

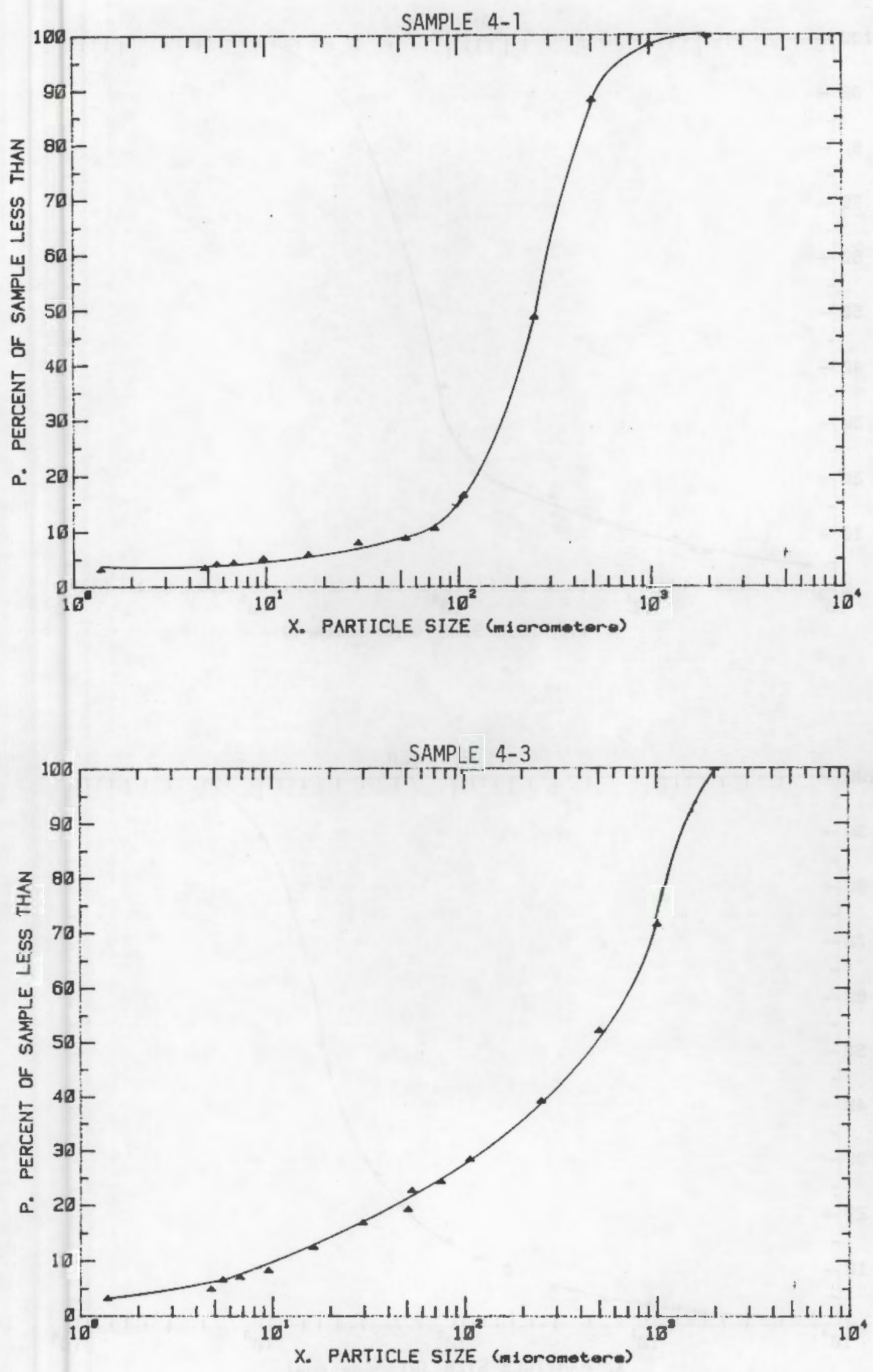

B. 13 


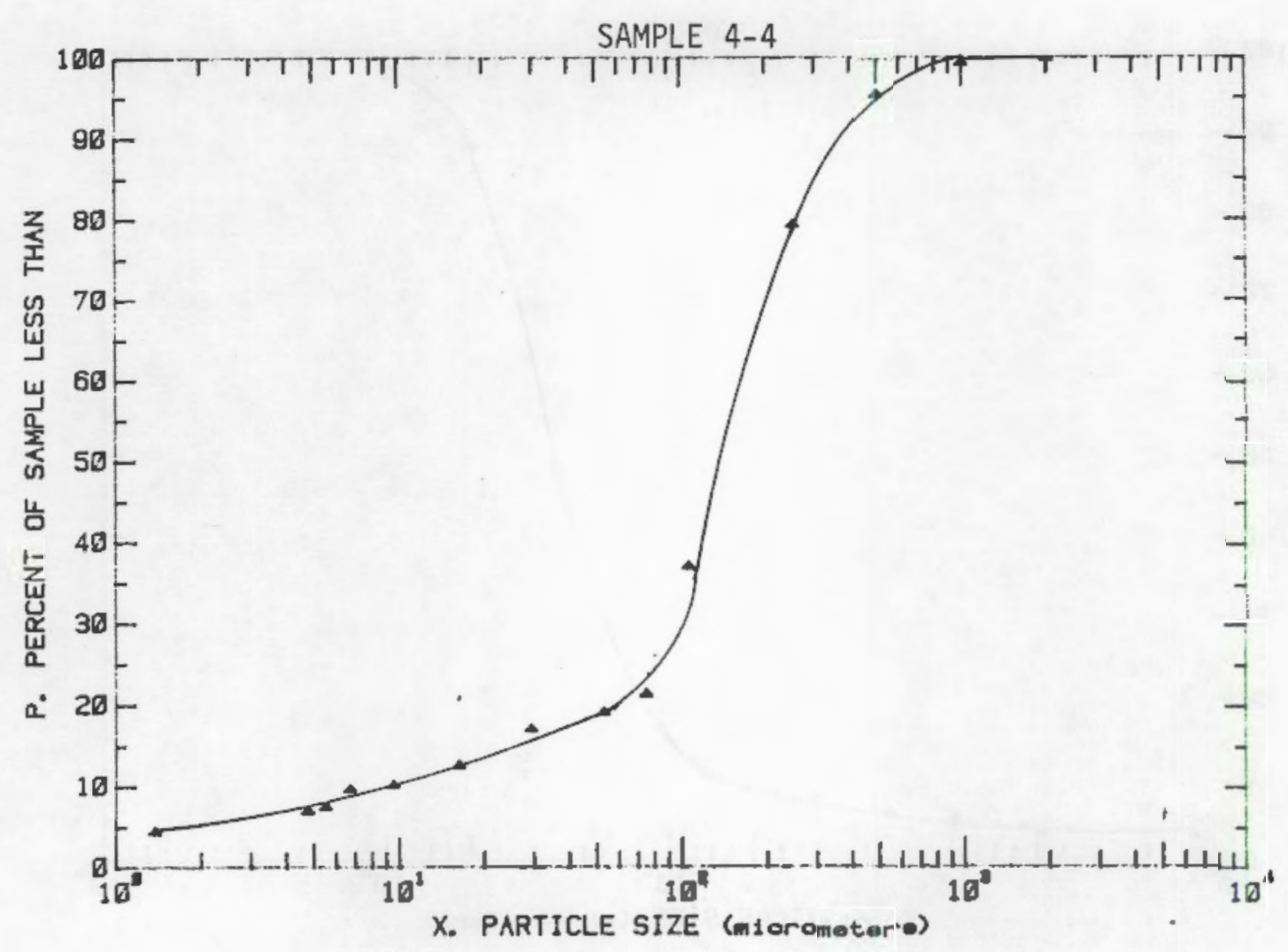

SAMPLE 4-8

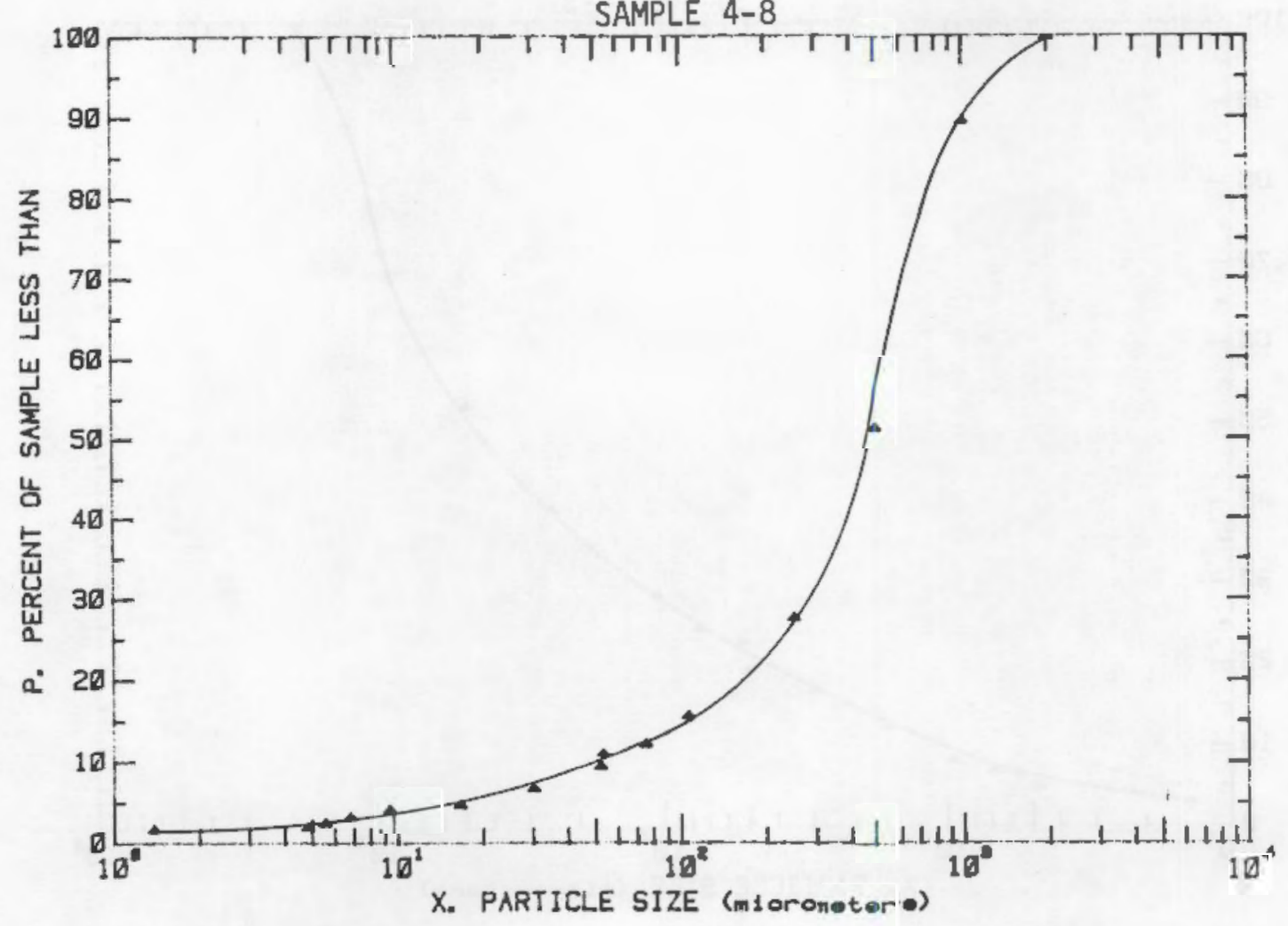

B. 14 

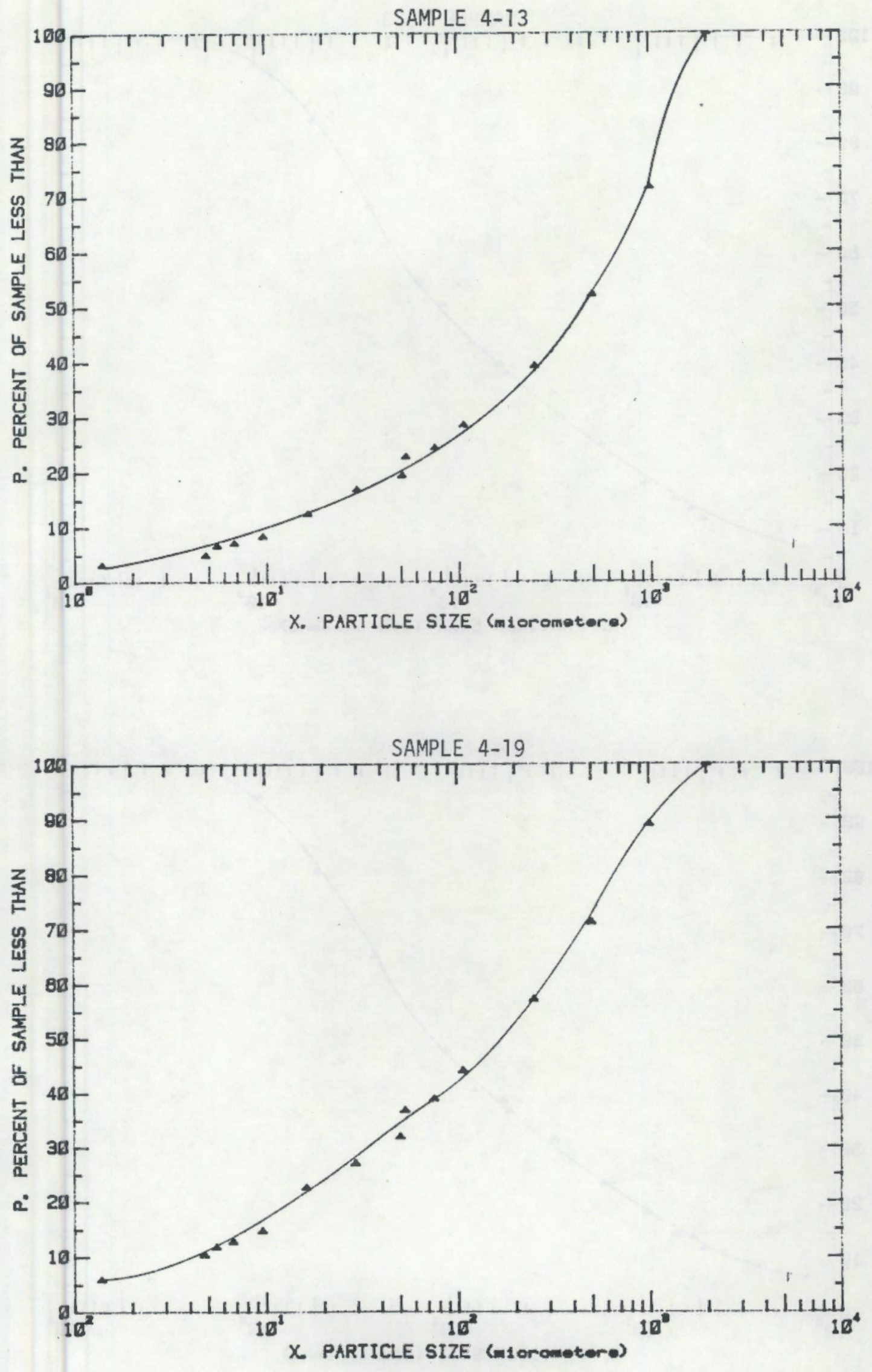

B. 15 
SAMPLE $\quad 4-23$

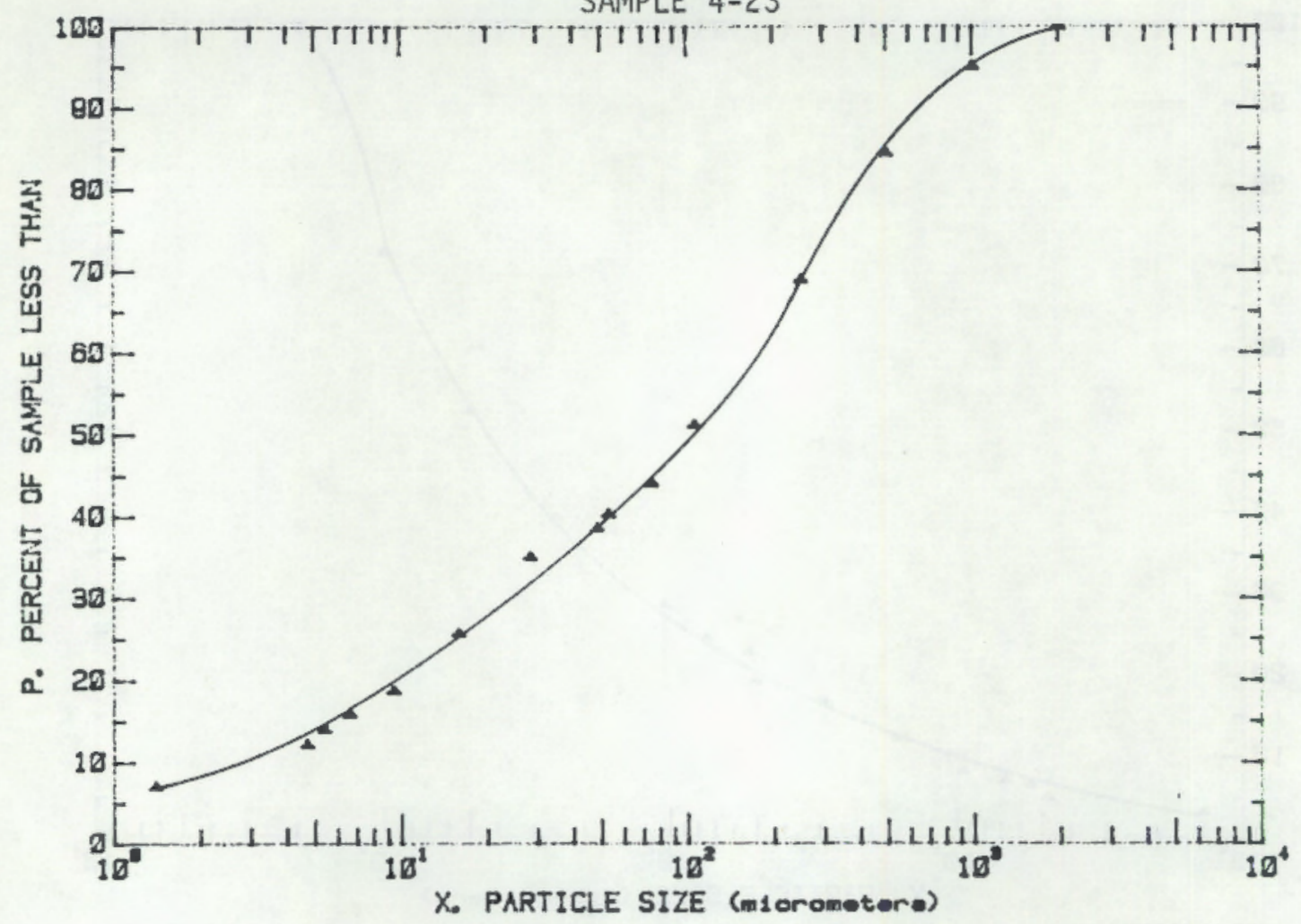

SAMPLE 4-25

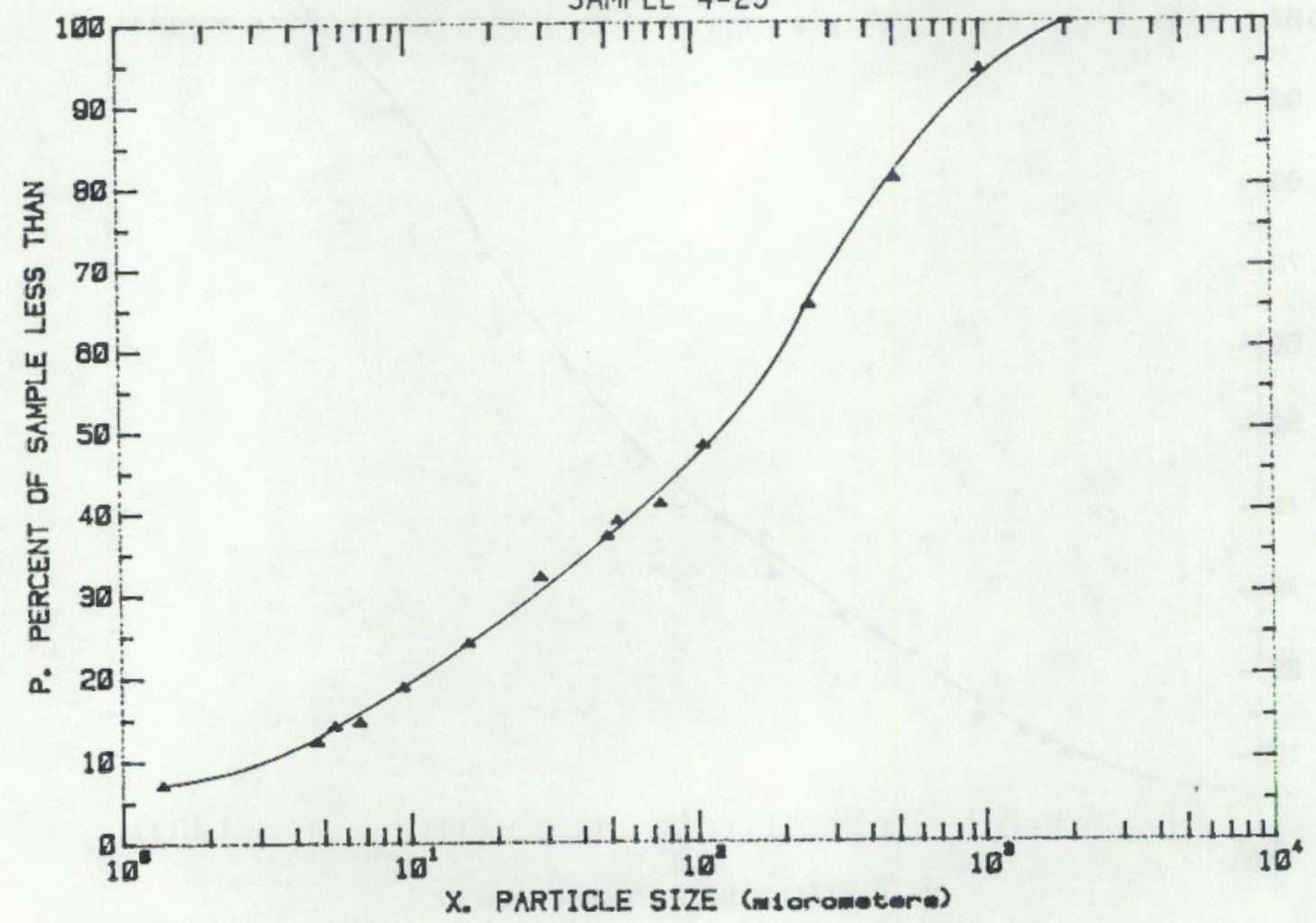

B. 16 
SAMPLE 5-1

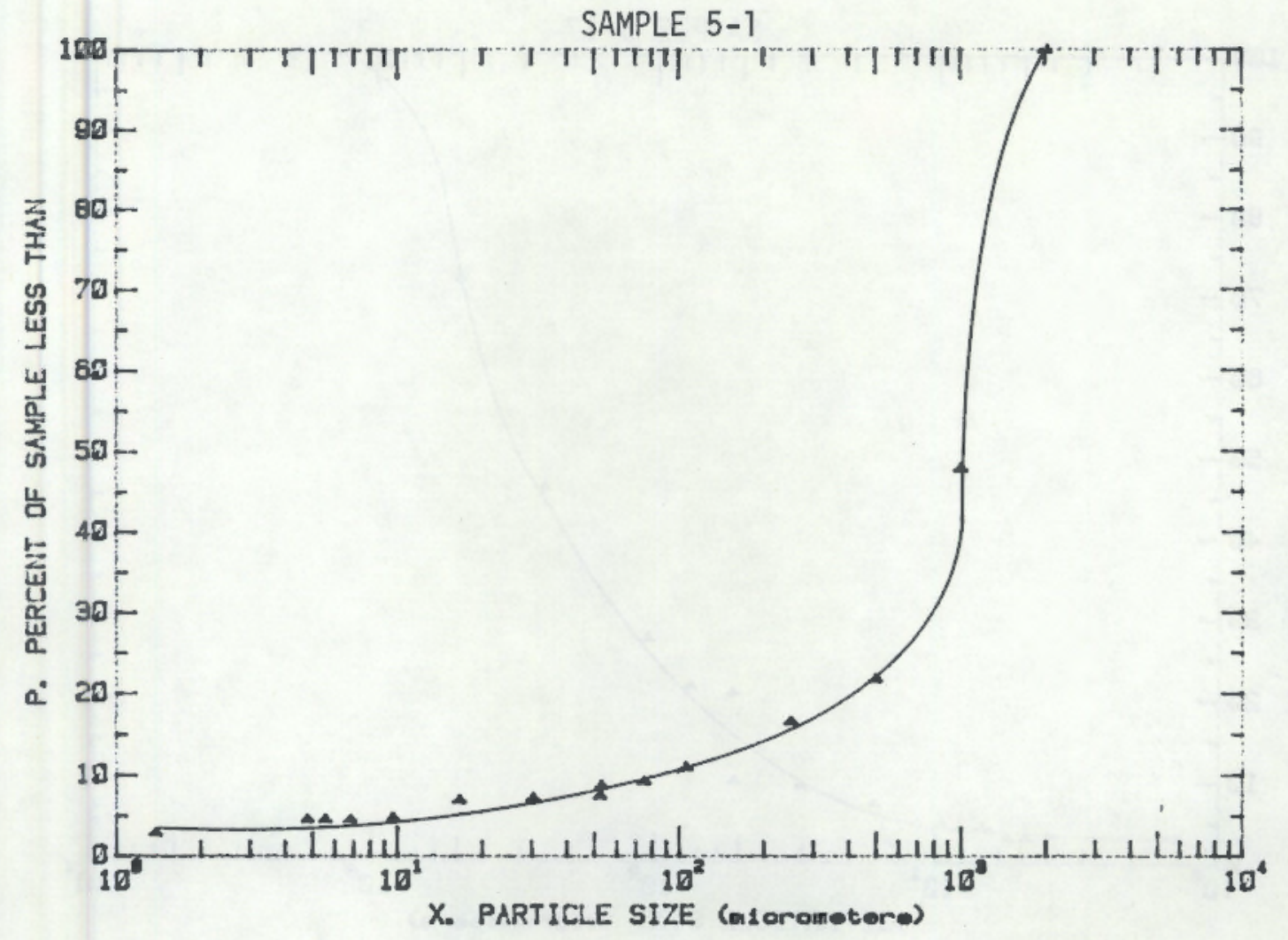

SAMPLE 5-15

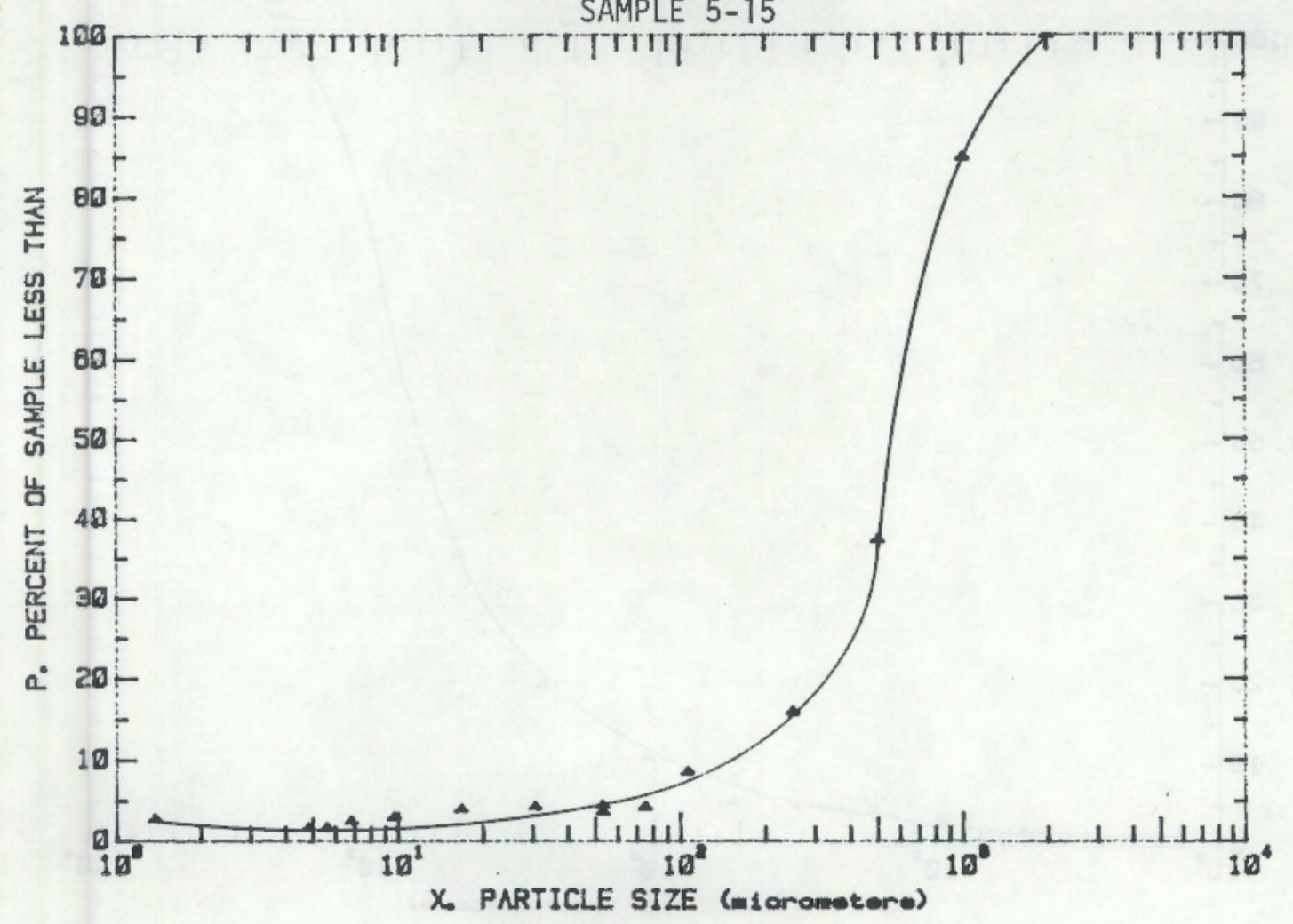

B. 17 


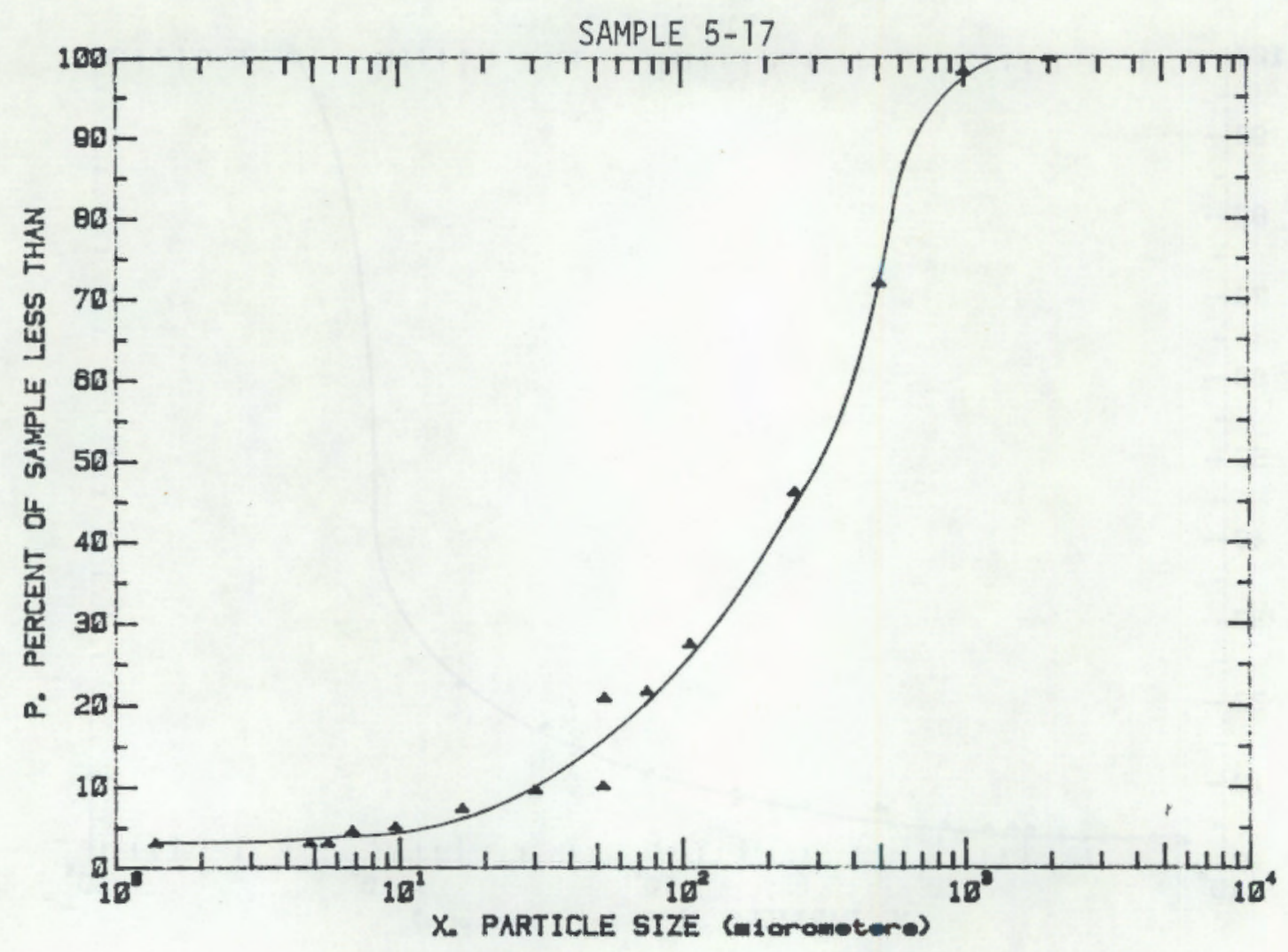

SAMPLE 5-23

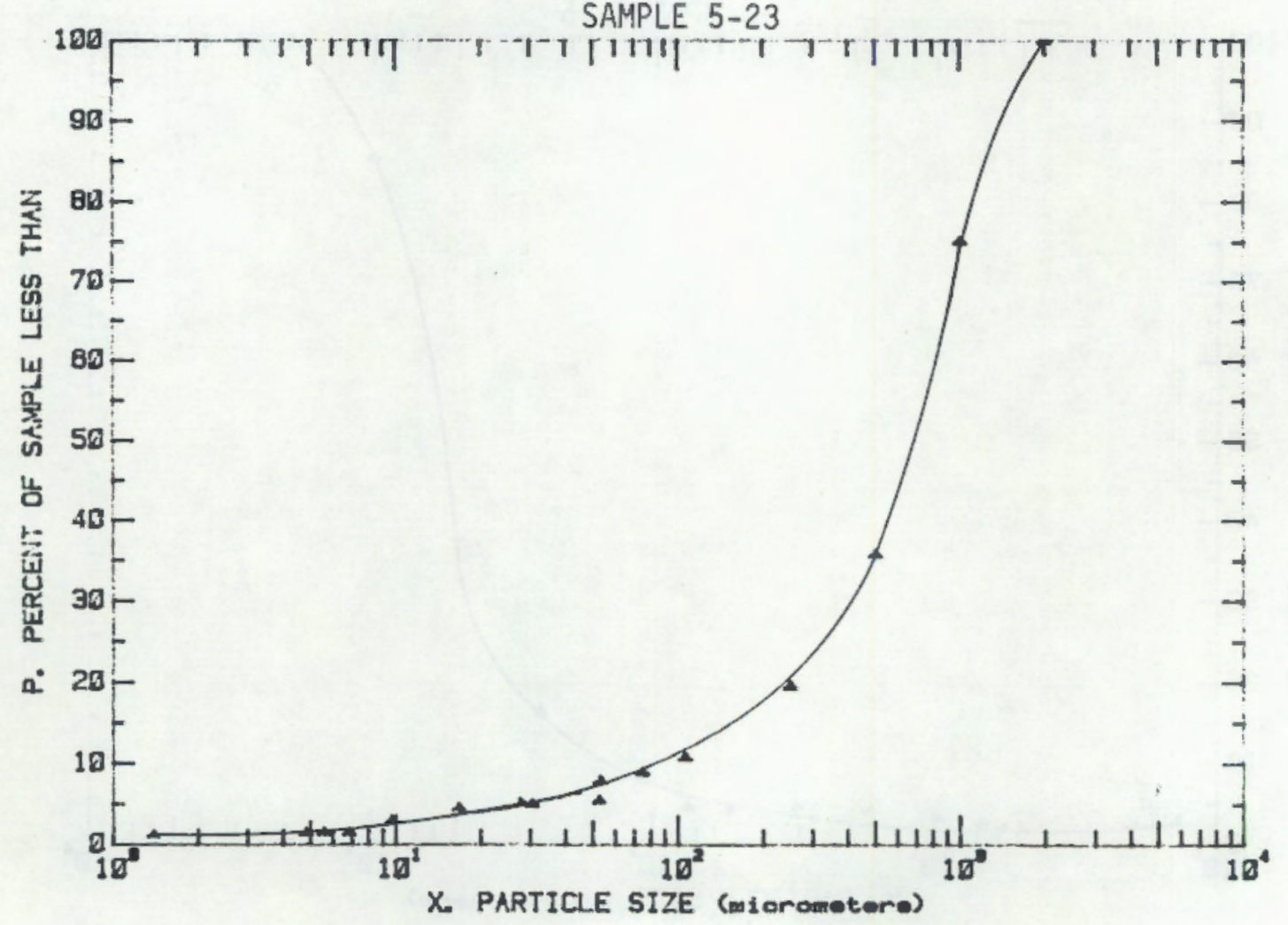

B. 18 
SAMPLE 5-33

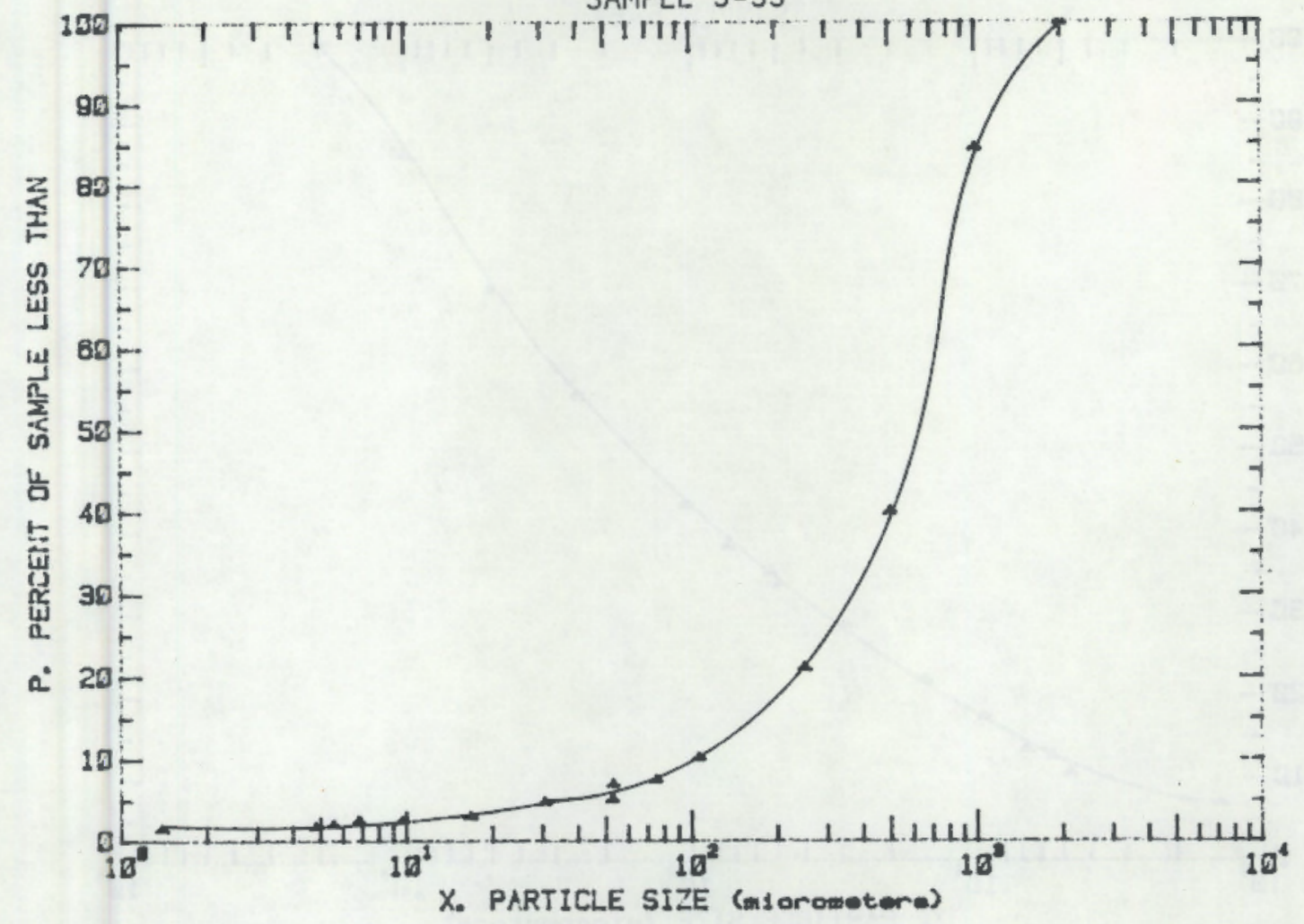

SAMPLE 5-45

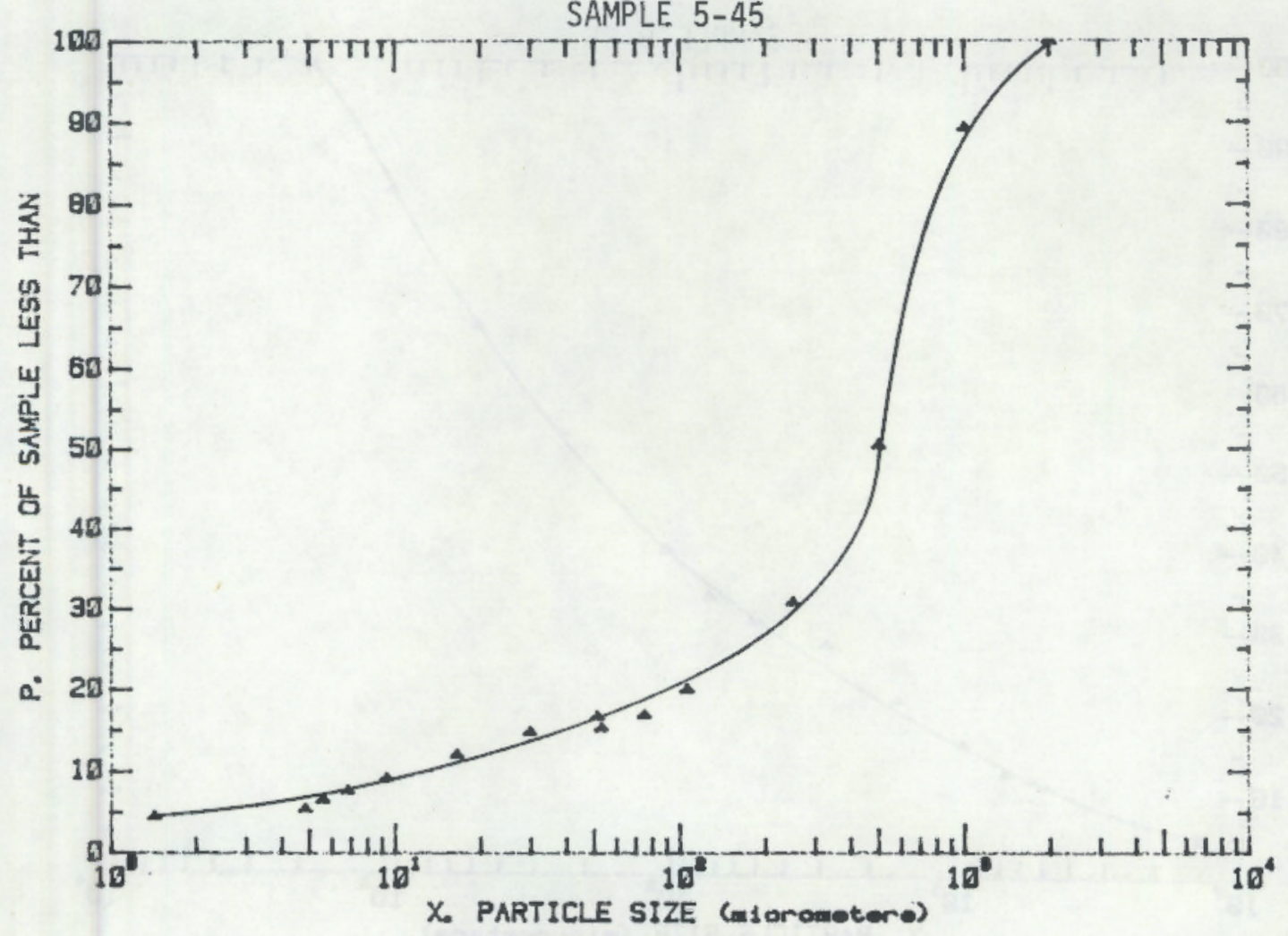

B. 19 
SAMPLE 5-5]

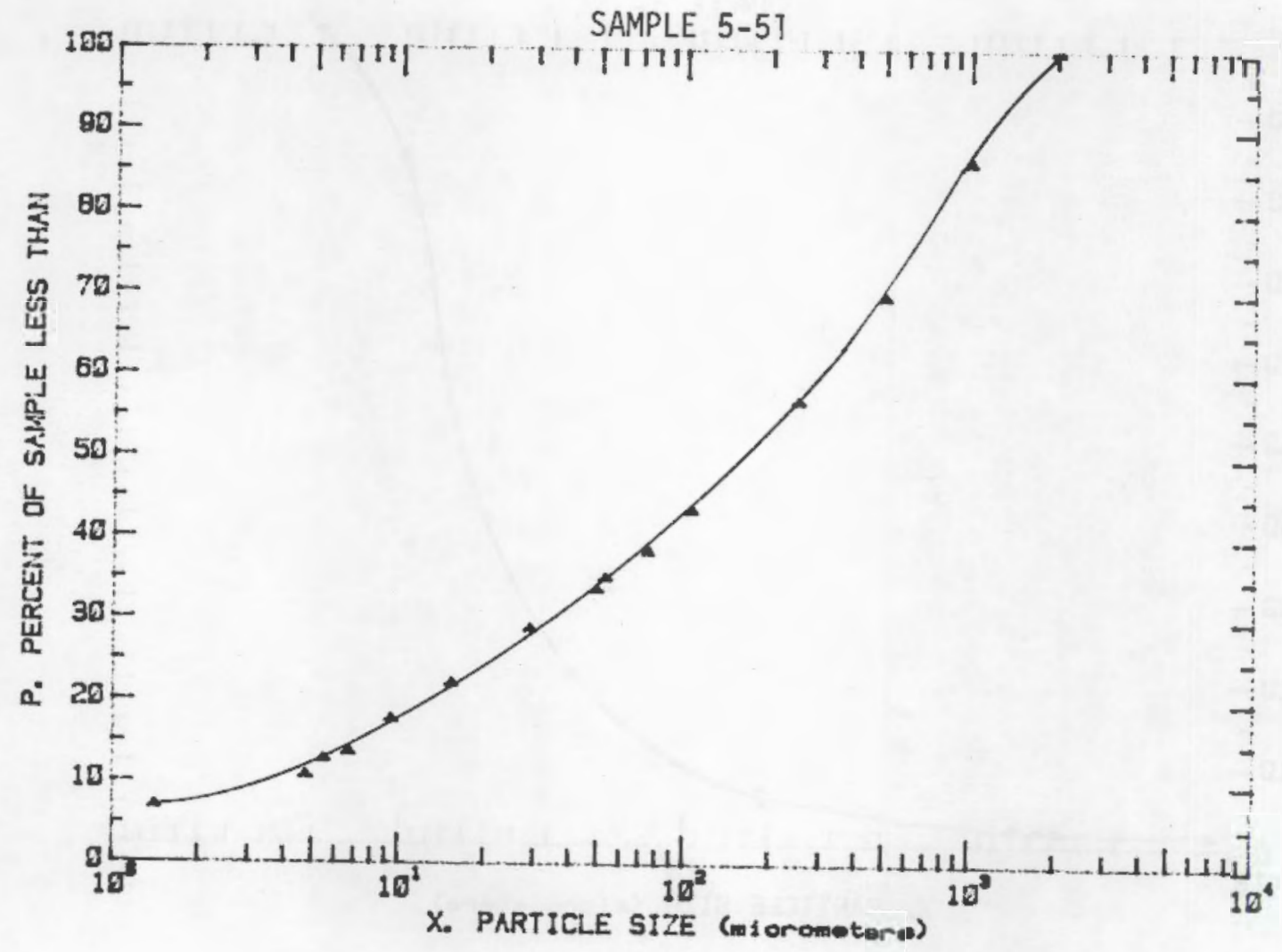

SAMPLE 5-55

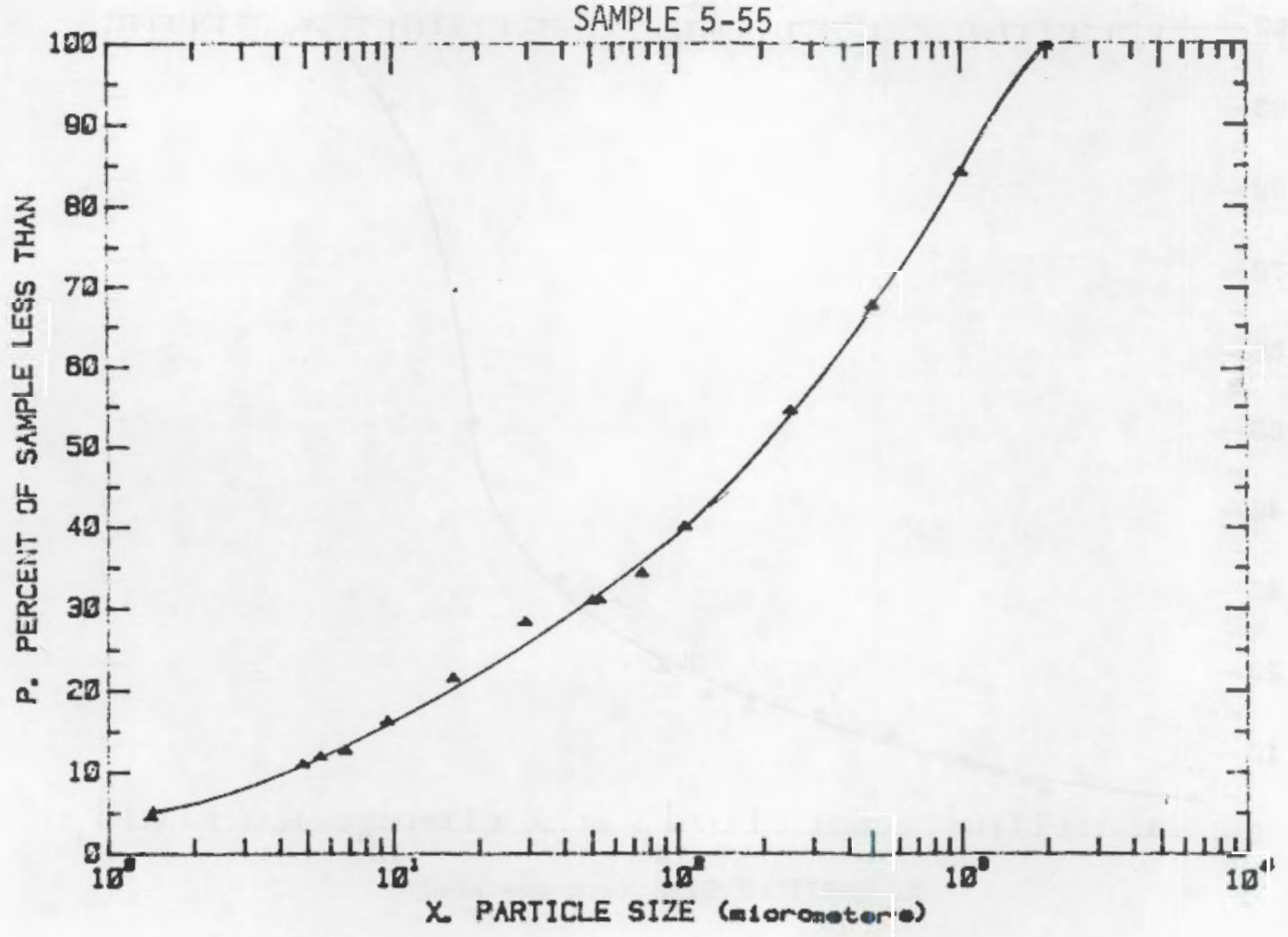


APPENDIX C

DRY SIEVE ANALYSIS 
TABLE C.1. Ory Sieve Analysis for Samples from Five Wells near the Hanford Wye Barricade

Percentage Less than

\begin{tabular}{|c|c|c|c|c|c|c|c|}
\hline Sample & in. & in. & lin. & $3 / 4$ in. & $1 / 2$ in. & $4.75 \mathrm{~mm}$ & $2.0 \pi$ \\
\hline $1-26$ & 100.0 & 100.0 & 99.2 & 98.2 & 96.4 & 89.2 & 75.4 \\
\hline $1-1$ & 100.0 & 100.0 & 97.7 & 97.1 & 96.4 & 94.6 & 85.5 \\
\hline $1-2$ & 100.0 & 100.0 & 99.2 & 99.0 & 97.9 & 93.9 & 75.2 \\
\hline $1-3$ & 100.0 & 100.0 & 100.0 & 100.0 & 99.2 & 98.3 & 91.6 \\
\hline $1-4$ & 100.0 & 100.0 & 100.0 & 100.0 & 100.0 & 100.0 & 100.0 \\
\hline $1-5$ & 100.0 & 100.0 & 100.0 & 100.0 & 100.0 & 100.0 & 100.0 \\
\hline $1-6$ & 100.0 & 100.0 & 100.0 & 100.0 & 100.0 & 100.0 & 100.0 \\
\hline $1-7$ & 100.0 & 100.0 & 100.0 & 100.0 & 100.0 & 100.0 & 100.0 \\
\hline $1-8$ & 100.0 & 100.0 & 100.0 & 100.0 & 100.0 & 100.0 & 99.9 \\
\hline $1-9$ & 100.0 & 98.1 & 91.1 & 84.2 & 74.0 & 49.8 & 31.1 \\
\hline $1-10$ & 100.0 & 98.9 & 73.8 & 71.3 & 64.6 & 47.1 & 31.9 \\
\hline $1-11$ & 100.0 & 98.9 & 92.8 & 87.5 & 77.6 & 51.4 & 30.5 \\
\hline $1-12$ & 100.0 & 98.8 & 92.0 & 87.2 & 77.9 & 57.5 & 38.0 \\
\hline $1-13$ & 100.0 & 95.3 & 87.6 & 81.8 & 74.1 & 55.5 & 36.2 \\
\hline $1-14$ & 100.0 & 100.0 & 98.7 & 98.1 & 96.6 & 86.9 & 62.2 \\
\hline $1-15$ & 100.0 & 100.0 & 99.4 & 98.4 & 97.3 & 92.9 & 77.0 \\
\hline $1-16$ & 100.0 & 98.3 & 96.1 & 94.1 & 92.1 & 84.9 & 70.2 \\
\hline $1-17$ & 100.0 & 100.0 & 100.0 & 99.9 & 99.3 & 94.8 & 77.7 \\
\hline $1-18$ & 100.0 & 100.0 & 100.0 & 99.6 & 99.5 & 99.3 & 96.1 \\
\hline $1-19$ & 100.0 & 100.0 & 100.0 & 99.8 & 99.5 & 99.1 & 95.6 \\
\hline $1-20$ & 100.0 & 100.0 & 98.2 & 97.5 & 96.3 & 93.0 & 88.5 \\
\hline $1-21$ & 100.0 & 100.0 & 100.0 & 100.0 & 99.7 & 99.3 & 96.8 \\
\hline $1-22$ & 100.0 & 100.0 & 99.5 & 99.1 & 98.0 & 95.4 & 86.5 \\
\hline $1-23$ & 100.0 & 100.0 & 99.3 & 97.1 & 91.0 & 63.7 & 43.5 \\
\hline $1-24$ & 100.0 & 100.0 & 98.9 & 96.8 & 92.6 & 72.8 & 53.3 \\
\hline $1-25$ & 72.6 & 64.8 & 61.2 & 57.3 & 53.3 & 45.8 & 41.4 \\
\hline $2-1$ & 97.2 & 97.2 & 90.5 & 88.0 & 85.3 & 79.0 & 57.1 \\
\hline $2-2$ & 100.0 & 98.5 & 89.9 & 86.9 & 84.2 & 78.0 & 59.4 \\
\hline $2-3$ & 100.0 & 98.5 & 98.3 & 98.1 & 97.5 & 91.3 & 88.7 \\
\hline $2-4$ & 100.0 & 92.0 & 85.1 & 81.7 & 77.3 & 71.6 & 59.6 \\
\hline $2-5$ & 100.0 & 100.0 & 92.0 & 89.2 & 86.0 & 81.8 & 70.8 \\
\hline $2-6$ & 100.0 & 100.0 & 98.7 & 97.9 & 97.0 & 94.2 & 85.6 \\
\hline $2-7$ & 100.0 & 100.0 & 100.0 & 100.0 & 100.0 & 100.0 & 98.7 \\
\hline $2-8$ & 100.0 & 95.8 & 94.8 & 94.3 & 93.9 & 93.3 & 91.5 \\
\hline $2-9$ & 100.0 & 100.0 & 99.1 & 98.7 & 98.5 & 98.0 & 95.6 \\
\hline $2-10$ & 100.0 & 96.4 & 94.3 & 93.3 & 91.6 & 88.5 & 80.5 \\
\hline $2-11$ & 100.0 & 100.0 & 99.2 & 98.7 & 97.7 & 95.5 & 87.7 \\
\hline $2-12$ & 98.7 & 98.7 & 98.3 & 98.2 & 97.4 & 96.3 & 90.7 \\
\hline $2-13$ & 100.0 & 100.0 & 99.2 & 99.0 & 98.6 & 97.7 & 94.4 \\
\hline $2-14$ & 100.0 & 100.0 & 99.9 & 99.9 & 99.8 & 99.4 & 97.3 \\
\hline $2-15$ & 100.0 & 100.0 & 100.0 & 99.9 & 99.6 & 99.0 & 97.0 \\
\hline $2-16$ & 100.0 & 100.0 & 99.4 & 98.9 & 98.3 & 97.8 & 95.8 \\
\hline $2-17$ & 100.0 & 100.0 & 99.8 & 99.7 & 99.3 & 99.0 & 97.0 \\
\hline $2-18$ & 100.0 & 100.0 & 100.0 & 100.0 & 100.0 & 99.9 & 98.0 \\
\hline
\end{tabular}


TABLE C.1. (contd)

Percentage Less Than

\begin{tabular}{|c|c|c|c|c|c|c|c|}
\hline imple & $3 \mathrm{in.}$ & $2 \mathrm{in}$. & 1 in. & $3 / 4$ in. & $1 / 2$ in. & $4.75 \mathrm{~mm}$ & $2.0 \mathrm{~mm}$ \\
\hline $\begin{array}{l}2-19 \\
2-20\end{array}$ & $\begin{array}{r}100.0 \\
95.0\end{array}$ & $\begin{array}{l}96.7 \\
88.1\end{array}$ & $\begin{array}{l}90.3 \\
79.0\end{array}$ & $\begin{array}{l}87.5 \\
76.1\end{array}$ & $\begin{array}{l}81.7 \\
70.2\end{array}$ & $\begin{array}{l}66.3 \\
56.0\end{array}$ & $\begin{array}{l}49.9 \\
43.0\end{array}$ \\
\hline $\begin{array}{l}3-1 \\
3-2 \\
3-3 \\
3-4 \\
3-5 \\
3-6 \\
3-7 \\
3-8 \\
3-9 \\
3-10 \\
3-11 \\
3-12 \\
3-13 \\
3-14 \\
3-15 \\
3-16 \\
3-17\end{array}$ & $\begin{array}{l}100.0 \\
100.0 \\
100.0 \\
100.0 \\
100.0 \\
100.0 \\
100.0 \\
100.0 \\
100.0 \\
100.0 \\
100.0 \\
100.0 \\
100.0 \\
100.0 \\
100.0 \\
100.0 \\
100.0\end{array}$ & $\begin{array}{l}100.0 \\
100.0 \\
100.0 \\
100.0 \\
100.0 \\
100.0 \\
100.0 \\
100.0 \\
100.0 \\
100.0 \\
100.0 \\
100.0 \\
100.0 \\
100.0 \\
100.0 \\
100.0 \\
98.5\end{array}$ & $\begin{array}{r}100.0 \\
100.0 \\
100.0 \\
100.0 \\
99.0 \\
96.7 \\
99.5 \\
100.0 \\
99.7 \\
99.5 \\
99.5 \\
100.0 \\
100.0 \\
100.0 \\
100.0 \\
100.0 \\
94.8\end{array}$ & $\begin{array}{r}100.0 \\
100.0 \\
100.0 \\
99.5 \\
98.4 \\
95.0 \\
98.8 \\
99.9 \\
99.7 \\
99.4 \\
98.6 \\
99.3 \\
100.0 \\
100.0 \\
99.9 \\
100.0 \\
89.8\end{array}$ & $\begin{array}{r}100.0 \\
100.0 \\
100.0 \\
99.3 \\
97.8 \\
93.2 \\
98.0 \\
99.6 \\
99.6 \\
98.8 \\
97.6 \\
98.7 \\
100.0 \\
100.0 \\
99.9 \\
100.0 \\
81.9\end{array}$ & $\begin{array}{r}100.0 \\
100.0 \\
100.0 \\
98.6 \\
96.2 \\
90.8 \\
96.2 \\
98.9 \\
98.7 \\
96.3 \\
94.8 \\
97.1 \\
100.0 \\
100.0 \\
99.6 \\
99.8 \\
65.7\end{array}$ & $\begin{array}{r}99.1 \\
99.0 \\
100.0 \\
94.7 \\
89.5 \\
85.9 \\
89.2 \\
95.1 \\
93.8 \\
86.0 \\
87.9 \\
90.4 \\
99.1 \\
98.6 \\
95.4 \\
94.1 \\
54.0\end{array}$ \\
\hline $\begin{array}{l}4-1 \\
4-2 \\
4-3 \\
4-4 \\
4-5 \\
4-6 \\
4-7 \\
4-8 \\
4-9 \\
4-10 \\
4-11 \\
4-12 \\
4-13 \\
4-14 \\
4-15 \\
4-16\end{array}$ & $\begin{array}{l}100.0 \\
100.0 \\
100.0 \\
100.0 \\
100.0 \\
100.0 \\
100.0 \\
100.0 \\
100.0 \\
100.0 \\
100.0 \\
100.0 \\
100.0 \\
100.0 \\
100.0 \\
100.0\end{array}$ & $\begin{array}{r}100.0 \\
98.5 \\
100.0 \\
100.0 \\
100.0 \\
100.0 \\
98.8 \\
100.0 \\
100.0 \\
98.1 \\
99.0 \\
100.0 \\
100.0 \\
100.0 \\
98.8 \\
99.0\end{array}$ & $\begin{array}{r}100.0 \\
94.4 \\
94.8 \\
100.0 \\
100.0 \\
99.7 \\
97.5 \\
99.9 \\
98.7 \\
96.0 \\
96.1 \\
99.3 \\
94.8 \\
96.1 \\
94.9 \\
95.1\end{array}$ & $\begin{array}{r}100.0 \\
92.3 \\
91.3 \\
100.0 \\
100.0 \\
99.7 \\
97.3 \\
99.2 \\
97.1 \\
94.5 \\
94.4 \\
97.7 \\
89.7 \\
93.5 \\
90.9 \\
91.9\end{array}$ & $\begin{array}{r}100.0 \\
90.2 \\
88.7 \\
100.0 \\
100.0 \\
99.7 \\
97.2 \\
98.3 \\
94.6 \\
93.4 \\
91.6 \\
90.2 \\
82.0 \\
89.4 \\
85.0 \\
87.3\end{array}$ & $\begin{array}{r}100.0 \\
86.1 \\
79.3 \\
100.0 \\
100.0 \\
99.5 \\
96.9 \\
96.1 \\
92.2 \\
92.4 \\
80.3 \\
67.8 \\
63.9 \\
75.0 \\
71.5 \\
74.6\end{array}$ & $\begin{array}{r}98.4 \\
76.3 \\
60.7 \\
100.0 \\
97.9 \\
93.3 \\
95.5 \\
89.6 \\
87.5 \\
89.7 \\
65.1 \\
50.1 \\
46.1 \\
52.2 \\
51.3 \\
51.3\end{array}$ \\
\hline $\begin{array}{l}5-1 \\
5-3 \\
5-5 \\
5-7 \\
5-9 \\
5-11 \\
5-13\end{array}$ & $\begin{array}{l}100.0 \\
100.0 \\
100.0 \\
100.0 \\
100.0 \\
100.0 \\
100.0\end{array}$ & $\begin{array}{r}98.7 \\
98.9 \\
100.0 \\
100.0 \\
100.0 \\
100.0 \\
97.8\end{array}$ & $\begin{array}{r}97.6 \\
98.2 \\
99.9 \\
99.8 \\
100.0 \\
99.7 \\
93.6\end{array}$ & $\begin{array}{r}95.7 \\
97.1 \\
99.9 \\
99.8 \\
100.0 \\
99.6 \\
91.4\end{array}$ & $\begin{array}{r}93.6 \\
95.1 \\
99.8 \\
99.6 \\
100.0 \\
99.4 \\
89.3\end{array}$ & $\begin{array}{l}87.9 \\
91.1 \\
99.0 \\
98.8 \\
99.6 \\
98.7 \\
86.2\end{array}$ & $\begin{array}{l}63.3 \\
74.9 \\
88.3 \\
93.3 \\
96.0 \\
93.9 \\
79.7\end{array}$ \\
\hline
\end{tabular}


TABLE C.1. (contd)

\begin{tabular}{|c|c|c|c|c|c|c|c|}
\hline \multirow{2}{*}{ Sample } & \multicolumn{7}{|c|}{ Percentage Less Than } \\
\hline & 3 in. & $2 \mathrm{in}$. & 1 in. & $3 / 4$ in. & $1 / 2$ in. & $4.75 \mathrm{~mm}$ & $2.0 \mathrm{~mm}$ \\
\hline $5-15$ & 100.0 & 100.0 & 99.4 & 99.2 & 98.8 & 97.1 & 92.4 \\
\hline & 100.0 & 100.0 & 98.9 & 98.6 & 97.6 & 91.6 & 77.2 \\
\hline $5-19$ & 100.0 & 100.0 & 100.0 & 99.9 & 99.9 & 99.7 & 99.1 \\
\hline $5-21$ & 100.0 & 100.0 & 99.6 & 98.9 & 97.8 & 96.4 & 90.6 \\
\hline $5-23$ & 100.0 & 100.0 & 99.5 & 99.1 & 98.7 & 97.7 & 90.2 \\
\hline & 100.0 & 100.0 & 100.0 & 99.8 & 99.5 & 98.6 & 92.5 \\
\hline $5-27$ & 100.0 & 100.0 & 98.5 & 97.9 & 96.5 & 94.2 & 85.8 \\
\hline $5-29$ & 100.0 & 100.0 & 98.3 & 97.9 & 97.0 & 95.1 & 88.4 \\
\hline $5-31$ & 100.0 & 97.5 & 94.8 & 94.6 & 94.1 & 92.2 & 85.4 \\
\hline $5-33$ & 100.0 & 100.0 & 100.0 & 100.0 & 100.0 & 99.7 & 96.8 \\
\hline $5-35$ & 100.0 & 100.0 & 99.9 & 98.9 & 97.8 & 94.6 & 90.9 \\
\hline $5-37$ & 100.0 & 100.0 & 98.1 & 96.7 & 94.8 & 89.8 & 84.2 \\
\hline $5-39$ & 100.0 & 100.0 & 97.5 & 95.4 & 92.6 & 89.6 & 85.7 \\
\hline $5-41$ & 100.0 & 100.0 & 98.3 & 96.6 & 95.0 & 93.0 & 89.5 \\
\hline $5-43$ & 100.0 & 100.0 & 98.7 & 96.6 & 94.3 & 88.9 & 85.1 \\
\hline $5-45$ & 100.0 & 100.0 & 94.5 & 89.2 & 80.6 & 66.1 & 57.6 \\
\hline $5-47$ & 100.0 & 100.0 & 86.9 & 81.0 & 74.6 & 63.5 & 52.8 \\
\hline
\end{tabular}




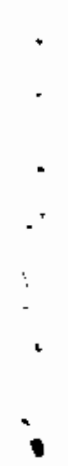

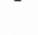


APPENDIX 0

TRAVEL TIMES IN THE UNSATURATED (VADOSE) ZONE 


\section{APPENDIX D}

\section{TRAYEL TIMES IN THE UNSATURATED (VADOSE) ZONE}

In this appendix we show how travel times for water in the unsaturated zone were calculated. The assumptions used in the analysis are presented and example calculations for computing total travel time through layered profiles are given.

\section{Flow Condition}

We assumed that unit hydraulic gradient conditions prevail:

$$
q=K(\theta)\left[1+\frac{\partial h(\theta)}{\partial z}\right]=K(\theta)
$$

where

$$
\begin{aligned}
\mathrm{q} & =\text { water flux in } \mathrm{cm} / \mathrm{yr} \text { (assumed constant) } \\
\mathrm{K}(\theta) & =\text { unsaturated hydraulic conductivity in } \mathrm{cm} / \mathrm{yr} \\
\mathrm{h} & =\text { suction head }=-\psi \text { (matric potential) } \\
\mathrm{z} & =\text { elevation. }
\end{aligned}
$$

2. Hydraulic Properties

We assumed simple analytical relationships between matric potential, $\psi$, and water content, $\theta$, and between conductivity and water potential (Campbe11 1974). These are

$$
\begin{aligned}
& \psi=\psi_{e}\left(\theta_{s} / \theta\right)^{b} \\
& k=k_{\text {sat }}\left(\psi_{e / \psi)^{n}}\right. \\
& n=2+3 / b
\end{aligned}
$$


where

$$
\begin{aligned}
\psi_{e}= & \text { air entry matric potential }(-\mathrm{cm}) \\
\theta_{s}= & \text { saturated water content }\left(\mathrm{cm}^{3} / \mathrm{cm}^{3}\right) \\
\theta= & \text { field water content }\left(\mathrm{cm}^{3} / \mathrm{cm}^{3}\right) \\
b= & \text { a constant, determined from the slope of a } \log -10 \mathrm{~g} \\
& \text { plot of } \psi \text { versus } \theta
\end{aligned}
$$

$\mathrm{K}_{\text {sat }}=$ saturated hydraulic conductivity.

From Equations (D.1), (D.2), and (D.3), the water content, $\theta$, can be expressed in terms of the steady water flux, $q$, and the saturated hydraulic conductivity, $\mathrm{K}_{\text {sat, }}$ as follows:

$$
\theta=w(q)=\left(\frac{q}{k_{s a t}}\right)^{m} \theta_{s}
$$

where $W(q)$ is the water content of the soil at a given water flux and

$$
m=\frac{1}{2 b+3} .
$$

3. Travel Time

The water velocity, $v$, can be defined as follows:

$$
v=q / \theta
$$

and travel time, T, can be defined as follows:

$$
T=L / v=L \theta / q
$$

where $L$ is profile thickness (length in cm).

4. Layered Profile

Assuming there are $n$ layers in the profile, then

$$
\begin{aligned}
& q=k_{i}\left(\theta_{i}\right) \quad(i=1, \ldots n) \\
& \theta_{i}=W_{i}(q)
\end{aligned}
$$

where $i$ is the soil layer index. 
The travel time in a layered system can be expressed in terms of a depth integral as

$$
T=\int_{0}^{L} \frac{d z}{v(z)}=\frac{1}{q} \int_{0}^{L} \theta(z) d z
$$

where $v(z)=$ velocity as a function of elevation, $z$.

For discrete layers, we can express the travel time as

$$
T_{i}=\frac{L}{q} W_{i}(q) f_{i}
$$

where $f_{j}=1$ ayer profile depth fraction

$$
\sum_{i}^{n} f_{i}=1 .
$$

The total travel time through the profile is the sum of the travel times through individual soil layers times the depth fraction, i.e.,

$$
T=\sum_{i}^{n} T_{i} f_{i} .
$$

\section{Example Calculations}

Data from borehole \#3 were used in the calculations. Two methods were used to estimate travel times. For Method 1, average water retention and conductivity values for the entire profile were determined. For ilethod 2, values for conductivity and water retention were averaged for three distinct layers: 0.0 to $5.2 \mathrm{~m}, 5.2$ to $23.3 \mathrm{~m}$, and 23.3 to $43.0 \mathrm{~m}$. The fractions, $f_{1}, f_{2}$, and $f_{3}$ were set at $0.12,0.42$, and 0.46 , respectively, to illustrate the use of the method. The water table was at $43 \mathrm{~m}$. We 
assumed two flux rates, 0.5 and $5.0 \mathrm{~cm} / \mathrm{yr}$. The resulting values for the calculations of the hydraulic properties are shown in Table 0.1 .

Table 0.2 shows the water content calculations based on the hydraulic properties in Table 0.1 and Equation (D.5).

TABLE D.1. Soil Properties for Travel Time Calculations

\begin{tabular}{|c|c|c|c|c|c|}
\hline Soil & Porosity & $\theta_{8}$ & $\begin{array}{l}K_{s a t} \\
\text { cingyt }\end{array}$ & $\begin{array}{l}\psi_{e}, \\
\mathrm{~cm}\end{array}$ & b \\
\hline 3-Ave & 0.38 & 0.34 & $1.0 \times 10^{5}$ & 11 & 2.8 \\
\hline $3 \mathrm{~A}$ & 0.43 & 0.39 & $3.4 \times 10^{4}$ & 7 & 2.0 \\
\hline $3 B$ & 0.39 & 0.35 & $2.3 \times 10^{5}$ & 5 & 2.1 \\
\hline $3 c$ & 0.36 & 0.32 & $7.3 \times 10^{3}$ & 18 & 4.8 \\
\hline
\end{tabular}

TABLE 0.2 Measured and Calculated Water Contents of Average Soil Profile and Selected Layers for a 0.5 and $5.0 \mathrm{~cm} / \mathrm{yr}$ Recharge Rate

\begin{tabular}{|c|c|c|c|}
\hline \multirow[b]{2}{*}{ Soil } & \multirow[b]{2}{*}{$\theta$ (Field) } & \multicolumn{2}{|c|}{$\begin{array}{l}\text { Water Content, } \\
\mathrm{m}^{3} / \mathrm{m}^{3}\end{array}$} \\
\hline & & $\theta(0.5)$ & $\vec{\theta}(\overline{5.0})$ \\
\hline 3-Ave & -- & 0.082 & 0.108 \\
\hline $3 A$ & 0.117 & 0.080 & 0.111 \\
\hline $3 B$ & 0.078 & 0.058 & 0.079 \\
\hline $3 c$ & -- & 0.150 & 0.180 \\
\hline
\end{tabular}

Calculated travel times for Method 1 (average) and Method 2 (layered system) are shown as follows:

a) $0.5 \mathrm{~cm} / \mathrm{yr}$ :

Method 1. From borehole $\$ 3$-Ave soil data (Table D.2) and using Equation (D.8),

$$
T=\frac{L \theta}{q}=\frac{4300}{0.5}(0.082)=710 \text { years } .
$$


Method 2. Using borehole \#3 data with layering $(A, B, C)$ from Equation (D.13),

$$
T=\frac{4300}{0.5}[(0.080)(0.12)+(0.058)(0.42)+(0.15)(0.46)]=890 \text { years } .
$$

b) $5.0 \mathrm{~cm} / \mathrm{yr}$ :

Method 1. From 3-Ave soil data (Table D.2) and using Equation (0.8),

$$
T=\frac{L \theta}{q}=\frac{4300}{5}(0.108)=93 \text { years } .
$$

Methor 2. Using $3 A, B$, and $C$ data, and Equation (0.13)

$$
T=\frac{4300}{5}[(0.111)(0.12)+(0.079)(0.42)+(0.18)(0.46)]=110 \text { years } .
$$

\section{REFERENCE}

Campbe11, G. S. 1974. "A Simple Method for Detemining Unsaturated Conductivity from Moisture Retention Data." Soil Sci. 117:311-314. 


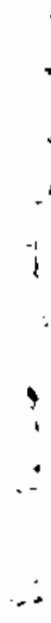




\section{DISTRIBUTION}

No. of

Copies

\section{OFFSITE}

D. E. Large, National Program Manager ORO Radioactive Waste Management Program

Oak Ridge Operations Branch

U.S. Department of Energy

P.0. Box E

Oak Ridge, TN 37830

L. J. Mezga, Program Manager

Low-Level Waste Management Program

Oak Ridge National Laboratory

P.O. Box $X$

Oak Ridge, TN 37830

M. J. Barainca, Program Manager

Low-Level Waste Management Program

Idaho Operations Office

U.S. Department of Energy

550 Second Street

Idaho Falls, ID 83401

\author{
R. Boland \\ Haste Management Project \\ Office \\ Nevada Operations Office \\ U.S. Department of Energy \\ P.i). Box 14100 \\ Las Vegas, NV 89114 \\ T. C. Chee \\ R\&? and Byproducts Division \\ DP-123 (GTN) \\ U.S. Department of Energy \\ Washington, DC 20545 \\ B. W. Church, Director \\ Health Physics Division \\ Nevada Operations Office \\ 11.S. Department of Energy \\ P.1). Box 14100 \\ Las Vegas, NV 89114
}

No. of

Copies

J. A. Coleman, Director

Division of Storage and Treatment Projects

NE-25 (GTN)

U.S. Department of Energy

Washington, DC 20545

נ. E. Dieckhoner, Acting Director

Operations and Traffic Division

DP-122 (GTN)

U.S. Department of Energy

Washington, DC 20545

C. P. Gertz, Chief

Radioactive Waste Technology Branch

Idaho Operations office

U.S. Department of Energy

550 Second Street

Idaho Falls, ID 83401

F. Gorup, Program Manager

Nuclear Waste Management Group

Chicago Operations Office

U.S. Department of Energy

9800 South Cass Avenue

Argonne, IL 60439

J. J. Jicha, Director

R\&D and Byproducts Division

DP-123 (GTN)

13.S. Departinent of Energy

Washington, DC 20545

E. A. Jordan

Low-Level waste Proyram Manager

Division of Storage and

Treatment Projects

NE-25 (GTN)

U.S. Department of Energy

Washington, DC 20545 
No. of

Copies

L. Lanni, Chief

Waste Management Nuclear

Magnetic Fusion Division

San Francisco Operations office

U.S. Department of Energy

1333 Broadway

0akland, CA 94612

8. Lawless

Process and Weapons Division

Savannah River Operations Office

U.S. Department of Energy

P.0. Box A

Aiken, SC 29801

J. M. McGough, Jr., Director

Waste Management and Transpor-

tation Development Division

Albuquerque Operations office

U.S. Department of Energy

P.0. Box 5400

Aibuquerque, NM1 87115

D. M. Lund

Waste Management and Transportation Development Division

Albuquerque Operations office

U.S. Department of Energy

P.0. Box 5400

Albuquerque, NM 87115

S. Mann, Senior Program Manager

Technical Management Division

Chicago Operations Office

U.S. Department of Energy

9800 South Cass Avenue

Argonne, IL 60439

C. L. Mathews, Chief

Fission Reactor Branch

Oak Ridge Operations Branch

U.S. Department of Energy

P.0. Box E

Oak Ridge, TN 37830
No. of

Copies

D. B. Leclaire, Director

Office of Defense Waste

and Byproducts Management

DP-12 (GTN)

U.S. Department of Energy

Washington, DC 20545

H. Saucier

Process and Weapons Division

Savannah River Operations Office

U.S. Department of Energy

P.0. Box A

Aiken, SC 29801

J. B. Whitsett, Chief

Production and Waste

Management Branch

Idaho Operations Office

U.S. Department of Energy

550 Second Street

Idaho Fal1s, ID 83401

30

DOE Technical Information Center

S. M. Brown, P.E.

Anderson-Nichols

2666 E. Bayshore Road

Palo Alto, CA 94303

C. S. Abrams, Manager of Radiological Engineering

Argonne National Laboratory west

P.0. Box 2528

Idaho Falls, ID 83401

J. Howard Kittel, Manager

Office of Waste Management Programs

Argonne National Laboratory

9700 S. Cass Avenue, Bldg. 205

Argonne, IL 60439

Technical Library

Argonne National Laboratory

Argonne, IL 60439 
No. of

Copies

Beverly Rawles

Battelle Memorial Institute

office of Nuclear Waste

Isolation

$505 \mathrm{King}$ Avenue

Columbus, $\mathrm{OH} 43201$

Peter Colombo, Group Leader

Nuclear Waste Research

Brookhaven National Laboratory

Building 701

Upton, NY 11973

R. H. Beers, Manager

Waste Management Programs

Division

EG\&G Idaho, Inc.

P.0. Box 1625

Idaho Falls, ID 83415

E. A. Jennrich

Low-Level Management

Program

EG\&G Idaho, Inc.

P.0. Box 1625

Idaho Falls, Idaho 83415

Environmental Protection Agency

Technology Assessment Division

Office of Radiation Programs

Washington, D.C. 20460

Jack G. Couch

Fermi National Accelerator

Laboratory

P.O. Box 500

Batavia, IL 60510

R. F. Anderson

Goodyear Atomic

P.0. Box 628

Piketon, $\mathrm{OH} 45661$

Technical Library

Idaho National Engineering Laboratory

Idaho Falls, Idaho 83401
No. of

Copies

Dr. T. Harvey

Mail Stop L-262

Lawrence Livermore National Laboratory

P.0. Box 808

Livermore, CA 94550

Donald T. Oakley

Program Manager for Waste Management

Los Alamos National Laboratory P.0. Box 1663

Los Alanos, NM 87545

T. Hakinson

Los Alamos Scientific Laboratory

Los Alamos, NM 87545

J. G. Steger

Los Alamos Scientific Laboratory

Los Alamos, NM 87545

Technical Library

Los Alamos National Laboratory

Los Alamos, New Mexico 87545

J. Mcilyenamin

Mason and Hanger - Silas

Mason Co.

Pantext Plant

P.0. Box 30020

Amarilio, TX 79177

R. R. Jaeger, Manager

Nuclear Waste Technology

Monsanto Research Corporation

P.0. Box 32

Miamisburg, OH 45342

National Academy of Sciences

National Research Council

2101 Constitution Avenue

Washington, DC 20413 
No. of

Copies

J. S. Baldwin

Low-Level Waste Management

Program

Oak Ridge National Laboratory

P.0. Box X

Oak Ridge, TN 37830

T. H. Row, Director

Nuclear Waste Programs

0ak Ridge National Laboratory

P.0. Box $X$

Oak Ridge, TN 37830

Technical Library

Oak Ridge National Laboratory

Oak Ridge, Tennessee 37830

E. W. Kendall

Waste Management Project

Manager

REECO

P.0. Box 642

Mercury, NV 89023

J. J. Blakeslee, Program Manager

Nuclear Waste Processing

Rockwell International

P.0. Box 464

Golden, CO 80401

C. E. Wickland

Manager, Waste Operations

Rockwell International

Rocky Flats Plant

P.0. Box 464

Golden, CO 80401

E. L. Albenesius

Savannah River Laboratory

P.0. Box A

Aiken, SC $2980 \mathrm{i}$

Technical Library

Savannah River National

Laboratory

Aiken, SC 29081
No. of

Copies

E. M. Romney

University of California

at Los Angeles

Westwood, CA 96137

W. A. Jury

Department of Soils

University of California

Riverside

Riverside, CA 92502

J. W. Cary

U.S. Department of Agriculture

Snake River Conservation

Research Center

Route 1, Box 186

Kimberly, ID 83341

Jack Fischer

Low-Level Radioactive waste

Proaram

U.S. Geological Survey

Water Resources Division

12201 Sunrise Valley Drive

Reston, VA 22092

I. J. Winograd

U.S. Geologic Survey

Reston, VA 22092

E. P. Weeks

U.S. Geological Survey

Federal Center Mail Stop 413

Denver, CO 80225

R. C. DeYoung

Division of Site Safety and

Environmental Analysis

U.S. Nuclear Regulatory

Commission

Washington, DC 20555

E. 0'Donnel1

Earth Sciences Branch

Division of Health, Siting and Waste Management Research

U.S. Nuclear Regulatory Commission

Washington, DC 20555 
No. of

Copies

$F$. Swanberg

Division of Health, Siting and Waste Management Research

U.S. Nuclear Regulatory Commission

Washington, DC 20555

G. S. Campbel1

Washington State University

Pullman, WA 99164

M. W. Boback, Director

Health and Safety Division

P.O. Box 39158

Cincinnati, $\mathrm{OH} \quad 45239$

M. D. Campbe11

U\&I Incorp.

Kennewick, HA 99336

\section{ONSITE}

Hanford Engineering Development Laboratory

R. E. Lerch

6 Richland Operations Office

M. W. Shupe

M. Dayani

G. Orten

H. E. Ransom

J. D. White

G. J. Miskho
No. of

Copies

6 Rockwell Hanford Operations

U. F. Albaugh

R. E. I saacson

W. A. Jordan

S. L. Phillips

3. F. Relyea

D. R. Myers

United Nuclear Industries

P. Ortiz

38 Pacific Northwest Laboratory

D. W. Dragnich

F. H. Dove

M. J. Fayer

M. D. Freshley

G. W. Gee (10)

M. J. Graham

$P$. C. Hays

P. R. Heller (2)

C. T. Kincaid

R. R. Kirkham

J. L. McElroy

D. A. Myers

R. W. Nelson

A. E. Reisenauer

J. V. Robinson

R. J. Serne

C. S. Simmons

D. R. Simpson

J. A. Stottlemyre

E. C. Watson

L. L. Wendell

Technical Information (5)

Publishing Coordination (2) 


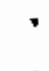

$+$

,

1

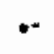

$\therefore$

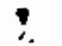

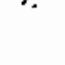

